Portland State University

PDXScholar

Winter 3-17-2014

\title{
A Global Investigation of Stakeholder and Contextual Influences on Firm Engagement in Sustainability
}

Annette M. Nemetz

Portland State University

Follow this and additional works at: https://pdxscholar.library.pdx.edu/open_access_etds

Part of the Business Law, Public Responsibility, and Ethics Commons, and the Sustainability Commons

Let us know how access to this document benefits you.

\section{Recommended Citation}

Nemetz, Annette M., "A Global Investigation of Stakeholder and Contextual Influences on Firm Engagement in Sustainability" (2014). Dissertations and Theses. Paper 1630.

https://doi.org/10.15760/etd.1629

This Dissertation is brought to you for free and open access. It has been accepted for inclusion in Dissertations and Theses by an authorized administrator of PDXScholar. Please contact us if we can make this document more accessible: pdxscholar@pdx.edu. 


\title{
A Global Investigation of
}

Stakeholder and Contextual Influences on

Firm Engagement in Sustainability

by

Annette M. Nemetz

A dissertation submitted in partial fulfillment of the requirements for the degree of

\author{
Doctor of Philosophy \\ in \\ Public Affairs and Policy
}

\author{
Dissertation Committee: \\ Craig Shinn, Chair \\ Jennifer Allen \\ Darrell Brown \\ Masami Nishishiba
}

Portland State University

2014 
(C) 2014 Annette M. Nemetz 


\begin{abstract}
Global sustainability issues cross all sectors of society, including businesses, governments, and communities and come with substantial costs. Business organizations are increasingly expected to address sustainability issues in a responsible manner and to disclose socially responsible behaviors accurately and transparently, showing that they are effective at managing and being proactive about sustainability challenges. In light of these pressures and expectations for business organizations, the fundamental research question for this study was whether variation existed in the levels of engagement in sustainability efforts across firms globally, and, more importantly, why such variation existed.
\end{abstract}

The level of strategic firm engagement in sustainability was proposed to be influenced by stakeholders and other factors that had relevance to sustainability. Three types of stakeholders with the potential power and legitimacy for influencing strategic decisions regarding firm engagement in sustainability were investigated - executive management, community and government. Multiple firm-related and country-related contextual factors were also investigated as influencers. The study was global in nature, consisting of four hundred companies in twenty-five countries.

Stakeholder theory, as the foundation of the investigation, was supported by the results of the study. Executive management, community, and government as stakeholders were found to have significant influence on the level of firm engagement in sustainability. Firm size, country economy, country technological readiness, country fossil fuel dependence, and industry sector were also found to have significant influence 
on the level of firm engagement in sustainability. Approximately $26 \%$ of the variation in firm sustainability engagement was accounted for by the combined influence of executive management, government and community as stakeholder influences and firm size and country technological readiness as contextual factors.

Specific findings showed that there were higher levels of firm engagement in sustainability when executive management provided explicit support for sustainability as a strategic issue; in communities with positive supportive norms for sustainability and a higher propensity for citizen-based political action; and when there was an optimal level of government regulation and formalized institutional power. Other factors that led to higher levels of firm engagement in sustainability were for firms in energy-related and automotive industry sectors, for larger firms based on revenue size, and for firms with headquarters located in countries with developed economies and higher technological readiness. 


\title{
Dedication
}

\begin{abstract}
Alan and Maddie,
This dissertation is dedicated to you.

The "book report" is complete!

You are my love and my life.
\end{abstract}




\section{Acknowledgements}

Many people have supported and encouraged me in the process of writing this dissertation and to all of you I extend my deepest gratitude and appreciation.

Most importantly, to Alan and Maddie, my wonderful family, I am so appreciative of you and the love that you show me every day. Thank you for bearing with me through this journey and for always being there for me. I owe you a huge debt of gratitude. I love you always and ever, bigger than the sky.

To Dr. Craig Shinn, my advisor and chair, thank you for your unfailing and continuous support, encouragement and excitement during this journey. Your warmth and dedication to your students is worthy of emulation.

To my committee members, including Dr. Shinn, Dr. Jennifer Allen, Dr. Darrell Brown, and Dr. Masami Nishishiba, you were each crucial to my success. Your guidance, questions and suggestions, while often difficult to hear, helped make this dissertation much, much better and I could not have done this without you. I am very grateful for the deep expertise and insights that each of you so willingly shared with me. You have shown me a path for aspiring to and accomplishing great research.

To my sister Dr. Patricia Nemetz Mills, you are such a wonderful sister, friend and colleague. The insights you gave me on the sometimes very esoteric world of scholarship and academia lifted my spirits and resolved any confusion I had. Thank you for always being there for me and for the love that we share as sisters. 
To my colleagues in the College of Business and in the Provost's office at George Fox University, you have encouraged me and supported me in many ways and I am grateful to be working with such wonderful colleagues.

To Dr. Deb Worden, your mentorship, caring, support, encouragement and willingness to listen are true gifts of friendship and collegiality. My appreciation for you runs very deep.

To the University of Portland, in particular Alan Timmins, Vice President of Finance, and Dr. Robin Anderson, Dean of the School of Business, many, many thanks for enabling me to have access to the Bloomberg terminals as a Visiting Scholar.

Finally, to all my friends and colleagues not yet mentioned, I am grateful for the interest and encouragement you showed throughout this process. 


\section{Table of Contents}

Abstract $\quad$ i

$\begin{array}{ll}\text { Dedication } & \text { ii }\end{array}$

Acknowledgements $\quad$ iv

List of Tables

List of Figures $\quad$ ix

Chapter 1. Introduction and Background $\quad 1$

Chapter 2. Review of Literature 10

Chapter 3. Research Design and Methods 24

$\begin{array}{ll}\text { Chapter 4. Analysis and Results } & 75\end{array}$

$\begin{array}{ll}\text { Chapter 5. Discussion } & 98\end{array}$

$\begin{array}{ll}\text { References } & 116\end{array}$

Appendix A. DJSI Industry Classifications 132

Appendix B. Number of Firms in DJSI List by Country 134

Appendix C. Bloomberg Environmental, Social and Governance Data 135

Appendix D. Government Environmental Regulatory Regime Index (ERRI) 137 Basis

Appendix E. World Values Survey Questions 138

Appendix F. World Bank/ISI List of Developing Countries (2010 - 2013) 140

Appendix G. The Global Competitiveness Report and GCI Technological 142 Readiness Scores 


\section{List of Tables}

Table 1. Descriptive Statistics of Firm Engagement in Sustainability for

Firms in Sample Set as Measured by FY2011 ESG Disclosure

Scores

Table 2. Executive Management Stakeholder Influence Indication as

Measured by Content in FY2011 Annual Report Showing

Strategic Support for Sustainability

Table 3. Descriptive Statistics of Firm Size for Firms in Sample Set as

Measured by 2011 Revenue (USD Billions)

Table 4. Descriptive Statistics of Firm Financial Performance Parameters

for Firms in Sample Set as Measured by ROA, ROE, and EBITDA (\%)

Table 5. Industry Sector Distribution of Firms in Sample Set as Measured

by DJSI Industry Classifications

Table 6. Community Stakeholder Composite Score Calculation Method

Table 7. Descriptive Statistics of Community Stakeholder for Firms in

Sample Set as Measured by Cultural Values for Sustainability and

Propensity for Citizen-Based Political Action (Composite Score, $\%$ of Country Population)

Table 8. Government Stakeholder Strength Based on ERRI for Countries in Sample Set

Table 9. Descriptive Statistics of Government Stakeholder for Firms in

Sample Set (International Dollars)

Table 11. Descriptive Statistics of Country Economy for Firms in Sample

Set as Measured by 2011 GDP per capita PPP (International

Dollars, thousands)

Table 12. Stage of Economic Development for Countries in Sample Set 
Table 13. Stage of Economic Development Distribution of Firms in Sample Set

Table 14. GCI Technological Readiness Scores for Countries in Sample Set

Table 15. Descriptive Statistics of Country Technological Readiness for Firms in Sample Set as Measured by 2011 Technological Readiness Score

Table 16. Amount of Electricity Produced by Fossil Fuels in 2011 for Countries in Sample Set (\%)

Table 17. Descriptive Statistics of Country Fossil Fuel Dependence for Firms in Sample Set as Measured by Amount of Electricity Produced by Fossil Fuels in 2011 (\%)

Table 18. ANOVA Statistics of Executive Management Stakeholder Influence on Firm Engagement in Sustainability

Table 19. ANOVA Statistics of Industry Segment Influence on Firm Engagement in Sustainability

Table 20. ANOVA Statistics of Country Variation in Firm Engagement in Sustainability

Table 21. ANOVA Statistics of Country Economy Influence on Firm Engagement in Sustainability as Measured by Stage of Economic Development

Table 22. Multiple Regression Statistics of the Relationships Between the Influence Factors and Firm Engagement in Sustainability 


\section{List of Figures}

Figure 1. Illustration of Proposed Relationships Between Individual

Influence Factors and Firm Engagement in Sustainability

Figure 2. Illustration of Proposed Relationships Between Combined

Influence Factors and Firm Engagement in Sustainability

Figure 4. Firm-Related Influence Factors: Hypotheses and Measurement Models

Figure 5. Country-Related Influence Factors: Hypotheses and Measurement Models

Figure 6. Analysis Model and Summary of Results

Figure 7. Scatter Plot of Government ERRI vs. ESG Disclosure Scores 


\section{Chapter 1}

\section{Introduction and Background}

The acceleration of globalization in recent years has increased the pressures on business organizations to engage in sustainable business practices (Quattrone \& Tversky, 1988). Globalization has been characterized as "the increasing interconnectedness of individuals, groups, companies and countries (Green \& Griffith, 2002, p.50)”. Although globalization leading to linkages among entities across the globe is not a new phenomenon, the bonds have increased substantially in recent years in intensity, scope and visibility, and have made sustainability issues more transparent (Green \& Griffith, 2002, p.51). Sustainability issues cross all sectors of society, including governments, businesses, non-profit organizations, and communities and come with substantial costs. In 2008, the estimated annual environmental costs from global human activity was US\$ 6.6 trillion, equating to $11 \%$ of global GDP (UNEP, PRI, \& Trucost, 2011). By 2050, environmental externality costs are estimated to be US\$28.6 trillion or $18 \%$ of global GDP (UNEP et al., 2011) and costs accounting for water pollution and water scarcity alone are estimated to reach US\$ 4.7 trillion, or $3 \%$ of global GDP (Baldinger \& Nothiger, 2011).

Sustainability has been defined as "the integration of social, environmental and economic considerations to make balanced judgments for the long term (Garriga \& Mele, 2004, p. 61; Poddi \& Vergalli, 2009, pp. 2-3).” As described by Rosenbaum (2011),

....an economically sustainable system must be able to produce goods and services on a continuing basis, to maintain manageable levels of government and external 
debt, and to avoid extreme sectoral balances, which damage agricultural and industrial production... a socially sustainable system must achieve distributional equity, adequate provision for social services including health and education, gender equality, and political accountability and participation ....an environmentally sustainable system must maintain a stable resource base, avoiding over-exploitation of renewable resource systems... and depleting nonrenewable resources... This includes maintenance of biodiversity, atmospheric stability, and other ecosystem functions (pp.22-23).

Economic benefits are frequently identified as the positive outcomes of globalization. Loosening of trade barriers, access to new and larger markets, growth and expansion of individual businesses, economic growth across nations, improvements in living standards, and increased flow of ideas and capital yield substantial benefits (Czinkota, Ronkainen, \& Moffett, 2009). Economic growth in many countries has been enhanced by trade, investment capital and labor moving more easily across borders, however, there have been costs associated with the economic benefits. Global movements may shift labor, compensation, production and capital from one economy to another, leading to potential inequalities among communities and societies. Economic differences may be substantial even if global competition is worldwide (Feiock, Moon, \& Park, 2008). Other global issues include cultural and societal problems, global environmental damage, lessening of sovereignty in nation-state governmental policy-making, and challenging intergovernmental cooperation (Green \& Griffith, 2002).

In the business sector, globalization has influenced products, services, and capital flows. Cultural, economic, political and technological global linkages are shaping the way business is conducted. Strategically, business must make choices regarding 
organizational structures, geographic distribution of corporate functions, changes in technology, workforce management and other operational concerns, including responding to sustainability challenges. Business organizations are faced with problems such as how to effectively and efficiently manage multicultural workplaces and how to respond to pressures to meet the needs of global and local conditions, including social needs, such as labor inequities, and environmental protection (Thomas, 2002).

Although sustainability impacts all sectors of society, business organizations hold a unique role. Business organizations have primary goals that support economic wealth creation but in the process they use environmental, human and capital resources and operate within communities of social and political norms. Business organizations are increasingly expected to pursue socially responsible and socially responsive behavior and to respond to a variety of stakeholder groups including shareholders, employees, interest groups, consumers, and government entities, taking into account not only profit-making capabilities in global markets but also responsiveness to social and environmental sustainability concerns (Brammer, Millington, \& Rayton, 2007). The pressures are not without basis. In 2008, the cost of environmental damage caused by the world's 3,000 largest publicly-listed companies was estimated to be US\$2.15 trillion or nearly $33 \%$ of the total environmental externality costs (UNEP, PRI, \& Trucost, 2011). Of the 3,000 companies, five industry sectors were responsible for $58 \%$ (US\$1.25 trillion) of the costs - Electricity (US\$404 billion), Oil \& Gas Producers (US\$303 billion), Industrial Metals \& Mining (\$219 billion), Food Producers (US\$197 billion), and Construction \& 
Materials (US\$123 billion) (UNEP et al., 2011). Costs include greenhouse gas emissions, air pollution, water abstraction, VOCs, general waste and heavy metals.

Sustainability actions undertaken by businesses are both mandatory and voluntary in nature. Mandatory actions include regulatory legal requirements, such as minimum pollution control standards or minimum labor conditions. Regulations may be complex, simple, or exist only marginally and vary substantially by country (Esty \& Porter, 2005). This distinction is critical because of the variability in actions that business organizations may make in response to government-supported coercive requirements or incentives toward sustainability challenges. Global governance institutions and frameworks have also been established that are relevant to sustainability in an effort to protect the global commons. Intergovernmental organizations, legal frameworks, financing institutions and organizations, such as the World Bank, and other multilateral mechanisms design and seek to implement treaty commitments that address common sustainability concerns globally, such as climate change and loss of biodiversity (Axelrod, Schreurs, \& Vig, 2011). Global governance impacts and includes not only governmental entities but also non-governmental entities such as business organizations and non-profit organizations (Frederickson, 2004; Gilpin, 2002; Keohane \& Nye, 2001; Krahmann, 2003). Treaty commitments by nations, however, are for the most part dependent on voluntary compliance by countries, with national sovereignty often holding primacy (Axelrod, Vandeveer, \& Downie, 2011). Business organizations may make choices that are influenced by governmental institutions, actions and preferences with respect to sustainability issues. 
In addition to government mandated requirements, sustainability initiatives undertaken by business organizations are also voluntary in nature, falling under the strategic initiatives of corporate social responsibility (Quattrone \& Tversky, 1988). Corporate social responsibility (CSR) has been defined as "actions taken by the firm intended to further social goods beyond the direct interests of the firm and that which is required by law (Doh \& Guay, 2006, p. 47; McWilliams \& Siegel, 2001)." Corporate social responsibility as a scholarly discipline is both normative and instrumental in nature. Much of the scholarship in corporate social responsibility has focused on normative theory debates, questioning what the role of business should be in society. Empirical studies of corporate social responsibility have addressed the strategic or financial advantages for the firm or have investigated factors that are associated with corporate social responsibility. In a 2008 survey by the Economic Intelligence Unit, approximately half of the responding firms thought of corporate social responsibility as a necessary cost of doing business and that engagement in corporate social responsibility actions provided a distinctive position in the market. ${ }^{1}$

A wide variety of descriptive labels have used to describe corporate social responsibility, including corporate citizenship, public responsibility, shared value, social and environmental issues management, stakeholder management, responsiveness to universal rights, and sustainable development or sustainability. Shared value is a recent concept that involves "...creating economic value in a way that also creates value for society by addressing its needs and challenges (Porter \& Kramer, 2011).”

\footnotetext{
${ }^{1}$ Source: Economist, January 17, 2008
} 
Motivation for businesses to engage in sustainability initiatives includes enhanced business results, such as higher profits and improved competitive advantages through lower costs, innovation and learning (KPMG, 2011; Tullis, 2011). For example, GE reported that it had saved $\$ 150$ million from 2005 to 2011 by limiting its carbon emissions, a substantial cost savings that came from improvements in its environmental practices (Tullis, 2011).

Sustainability and stakeholder management are themes that are commonly investigated under ethical or integrative theories of corporate social responsibility while instrumental corporate social responsibility theories focus on the corporation as a strategic instrument for wealth creation with social activities being perceived as a means to achieve economic results (Garriga \& Mele, 2004).

Of increasing strategic importance to business organizations is making transparent the level of sustainability in which the firm engages, particularly because of increasing pressures from stakeholders external to the firm, including interest groups, communities, consumers, shareholders, employees, and others. This means that not only are business organizations pressured to address sustainability issues in a responsible manner, but that there is also the expectation that firms will disclose socially responsible behaviors accurately and transparently, showing that they are effective at managing and being proactive about sustainability challenges.

Sustainability reporting is sometimes provided as an addition to financial reporting, particularly for large and publicly traded enterprises (KPMG, 2011). A 2011 survey conducted by KPMG of more than 3,400 companies found that sustainability 
reporting had become a de facto standard for businesses and that " ... corporate responsibility> reporting is now an essential requirement for any company hoping to be seen as a responsible corporate citizen (KPMG, 2011, p.7).”

The Global Reporting Initiative (GRI) ${ }^{2}$ and the United Nations Global Compact $(\mathrm{UNGC})^{3}$ are two organizations that have published reporting standards for sustainability measures. The standards are the foundation for Environmental/Social/Governance (ESG) disclosure scores that are developed from indicators such as greenhouse-gas intensity per sales, water usage, employee fatalities, toxic discharge, and board composition (Bloomberg, 2013; GRI, 2011; Tullis, 2011). Some business professionals argue that companies that take into account sustainability factors, also known as material extrafinancial factors, and that are adapting to sustainability challenges, are more likely to be successful and able to respond to changes in the competitive business environment caused by resource scarcity, climate change or other adversity (Baldinger \& Nothiger, 2011; Bloomberg, 2013; KPMG, 2011; Tullis, 2011).

In summary, sustainability is and will continue to be of critical global importance, and business organizations play an important role in meeting these challenges. Business organizations are increasingly pressured and have expectations to address sustainability issues and to transparently report on their efforts. In light of these pressures and expectations for business organizations, the fundamental research question for this study was whether variation exists in the levels of engagement in sustainability efforts across

\footnotetext{
${ }^{2}$ Source: https://www.globalreporting.org/Pages/default.aspx

${ }^{3}$ Source: http://www.unglobalcompact.org/
} 
firms, and, more importantly, why such variation exists. Stakeholders have been identified as potential influencers impacting a firm's strategic decisions to engage in sustainability (Brammer et al., 2007; Freeman, 2010; Frooman \& Murrell, 2005; Frooman, 1999; Hendry, 2005; Quattrone \& Tversky, 1988). This study tested whether stakeholders have influenced firm engagement in sustainability.

Stakeholders have been defined to be individuals, groups, or relationships that have an interest in a firm, whether or not the firm has a corresponding interest in the stakeholders, with the presumption that the interests of all stakeholders have intrinsic value (Donaldson \& Preston, 1995; Freeman, 1984; Freeman, 2010; Freeman et al., 2013; Mitchell, Agle, \& Wood, 1997). Influence strategies by stakeholders may include attempts to control resources in an effort to reduce interdependence and uncertainty (Pfeffer \& Salancik, 1978), with the implication that stakeholders take actions on the firm to meet their needs (Frooman, 1999). The intent of the study was to empirically test stakeholder theory and to provide additional evidence that stakeholders do influence a specific corporate objective, in this case, the level of sustainability in which a firm engages.

Firm strategy, however, is often formulated by taking into account not only pressures and influences such as may exist from stakeholders but also by considering other factors that may impact strategic decisions. Contextual intelligence has been defined as "...the profound sensitivity to macro-level contextual factors in the creation, growth, or transformation of business (R. J. Sternberg, 1988).” Contextual factors such as social, cultural, political, economic, technological, labor, industry and demographic 
forces or attributes may substantially influence strategic directions (David, 2011; Mayo \& Nohria, 2005; Parnell, 2014). The direction of this study was to investigate stakeholder and contextual influences relevant to sustainability and to determine whether influence from these impacted firm level of engagement in sustainability, as related to corporate social responsibility strategic initiatives. In summary, the research question may be stated as: are stakeholders important influencers in firm engagement in sustainability and do other factors positively or negatively influence firm engagement in sustainability?

The intention of this study was to add value for theory and for practice. In the literature, there are limited empirical studies of stakeholder influences or other influence factors on corporate social responsibility in business organizations. A major theoretical purpose was to contribute further evidence supporting stakeholder theory constructs and to open additional pathways for studying the influence of stakeholders and other influences on corporate social responsibility.

Developing deeper understanding of the factors that influence firm engagement in corporate social responsibility, particularly sustainability initiatives, may also provide practical insights for enhanced business strategy formulation including the importance of strategic sustainability initiatives and deeper understanding of the effects of contextual factors on decision-making, positive business practices for stakeholder responsiveness and engagement, influential corporate engagement strategies for stakeholders, effective government policy formulation for encouraging sustainability, and community advocacy strategies for sustainability. 


\section{Chapter 2}

\section{Review of Literature}

Corporate social responsibility is an extensively argued discipline in the academic

literature. A substantial portion of the literature focuses on theoretical arguments and approaches, particularly as related to normative studies of what the role of business is in society. Empirical studies on corporate social responsibility have largely focused on investigating whether corporate social responsibility engagement is a determinant of strategic or financial advantages for business organizations. A few empirical studies focused on investigating the potential factors that may influence a firm's strategic decisions regarding corporate social responsibility.

Stakeholder theory is tightly linked to corporate social responsibility. Stakeholder management is a construct or framework based on stakeholder theory that is frequently used to study corporate social responsibility as part of business strategy. Following is a review of the literature on these topics. ${ }^{4}$

\footnotetext{
${ }^{4}$ Corporate social performance (CSP) is sometimes differentiated in the literature from corporate social responsibility (CSR) as the portion of CSR that is related to the management of social issues by a corporate entity that is mainly instrumental in nature (Coffey \& Wang, 1998). CSP has been described as the responsiveness, policies, actions, and outcomes of CSR (Frederick, 1994; Wartick \& Cochran, 1985). Baron, Harjoto, \& Jo (2008) defined CSP as “.... satisfy<ing > two conditions...the social activities are beyond the requirements of the law and regulations...the social activities involve the private provision of public goods or redistribution. CSR implies CSP, but CSP need not be morally motivated (p. 2)." The terminology differentiation between CSR and CSP is important only because the two streams of literature can be inadvertently separated and both are generally relevant to the study of corporate social responsibility. Literature was searched using both terms, although corporate social responsibility is used in the literature review to include both CSR and CSP.
} 


\section{Corporate Social Responsibility}

Corporate social responsibility was defined by Bowen (1953) as “...the

obligations of businessmen to pursue those policies, to make those decisions, or to follow those lines of action which are desirable in terms of the objectives and values of our society (p. 6)." Many ideas about what corporate social responsibility is have since been proposed. The main dividing line conceptually has been focused on arguments about what the role of business is in society, with an expanse of ideas ranging from the primacy of shareholders as the only social responsibility of a corporation to the views that corporations must fully embrace concerns for the broader social system (Carroll, 1979, 1999). The lack of clarity in what constitutes corporate social responsibility conceptually was illustrated by Votaw (1972):

...corporate social responsibility means something, but not always the same thing to everybody. To some it conveys the idea of legal responsibility or liability; to others, it means socially responsible behavior in the ethical sense; to still others, the meaning transmitted is that of 'responsible for' in a causal mode; many simply equate it with a charitable contribution; some take it to mean socially conscious; many of those who embrace it most fervently see it as a mere synonym for legitimacy in the context of belonging or being proper or valid; a few see it a sort of fiduciary duty imposing higher standards of behavior on businessmen than on citizens at large (p.25).

A frequent criticism of corporate social responsibility is that it is a vague term that is highly subjective lacking a clear definition of what social means and how the term links to daily business activities (Jamali, 2008). In recent literature, a commonly used conceptual definition is that corporate social responsibility concerns actions taken by a 
firm intended to further social goods beyond the direct interests of the firm and above that which is required by law (Doh \& Guay, 2006; McWilliams \& Siegel, 2001).

Theoretical arguments supporting the broader social expectations of businesses have suggested that socially responsible behavior by business organizations is an obligation that provides value to both society and the businesses themselves. Often based on normative values of ethical obligations and the obligation of business to balance power and responsibility, arguments for business engagement in corporate social responsibility have included the potential for increased long-term profits due to improved corporate reputation, corporate possession of resources that should be used for public projects that need assistance, and proactive engagement as an aid in limiting governmental regulation (Robbins, DeCenzo, \& Coulter, 2011). Various motivations for corporations engaging in corporate social responsibility have been suggested, including moral imperatives, consumer rewards, investor rewards, employee and supplier rewards, deterrence from harmful social performance and as perquisites for management (Baron, Harjoto, \& Jo, 2008).

Corporate social responsibility theory is frequently critiqued as a violation of business responsibilities for shareholder value maximization. Other criticisms of corporate social responsibility include dilution of corporate purpose, increased costs borne unnecessarily by the corporation, inappropriate increase of power by businesses in the social arena, lack of skills within the business community to address social issues, and limited accountability by businesses for social actions (Robbins et al., 2011). 
According to Garriga \& Mele (2004), the corporate social responsibility field has a "proliferation of approaches, which are controversial, complex and unclear (p.51)." In their study, the authors classified the evolution of corporate social responsibility theories into four veins: instrumental, political, integrative and ethical theories. A brief summary of each theory stream follows.

Instrumental corporate social responsibility theories focus on the corporation as a strategic instrument for wealth creation with social activities being perceived solely as a means to achieve economic results. Concern for profits, however, does not exclude taking into consideration the interests of other stakeholders in the firm, as long as these contribute to the overall profitability. Empirical studies of corporate social responsibility are frequently instrumental in nature, typically investigating corporate social responsibility as related to the financial performance of the firm. Maximization of shareholder value, cost-benefit analyses, optimal resource allocation and cause-related marketing are common investigative approaches (Garriga \& Mele, 2004).

Political corporate social responsibility theories emphasize the social power of the corporation and the responsible use of this power in the political arena, with the organization accepting social duties and engaging in social cooperation. Corporate constitutionalism and corporate citizenship are major themes that have been investigated, with the study of corporate citizenship increasing due to the effects of increased globalization and a core assumption that businesses, particularly multinational corporations that have global impact and reach, have responsibility to local communities and to the environment (Garriga \& Mele, 2004). 
Integrative corporate social responsibility theories are built on a normative assumption that businesses should integrate social demands because businesses depend on society for existence, legitimacy, prestige, continuity and growth. Common investigative themes are issues management, public responsibility, corporate social performance, and stakeholder management (Garriga \& Mele, 2004).

Ethical corporate social responsibility theories are also normative in nature and are based on the assumption that the relationship between business and society is embedded with ethical values and principles of "the right thing to do or the necessity to achieve a good society (Garriga \& Mele, 2004).” Normative stakeholder management, universal rights, sustainable development, and the common good are major themes that are studied.

\section{Stakeholder Theory and Stakeholder Management}

Stakeholder theory and the related framework of stakeholder management are broadly based in the management field. Stakeholder theory is a general approach to analyzing how organizations are or should be managed and is placed in the management discipline alongside other theories of the firm, such as agency, behavioral, ecological, institutional, resource dependence, input-output, neoclassical, and transaction cost theories. Although used as analytical tools in several disciplines including strategic management, organization theory, public administration, and business ethics, stakeholder theory and stakeholder management are most closely linked to corporate social responsibility and the analysis of the social responsibility or the social accountability of a firm (Poddi \& Vergalli, 2009). 
The core thesis of stakeholder theory is that a firm is more effectively managed by taking into account all stakeholders, with a normative assumption that “...organizations should be managed in the interests of all their constituents, not only in the interest of shareholders (Laplume, Sonpar, \& Litz, 2008, p. 1153)." Stakeholders have been defined as individuals, groups or relationships that have an interest in a firm, whether or not the firm has a corresponding interest in the stakeholders, with the presumption that the interests of all stakeholders have intrinsic value (Donaldson \& Preston, 1995; Freeman, 1984; Freeman, 2010; Freeman et al., 2013; Mitchell, Agle, \& Wood, 1997). A major assumption of the theory is that organizations manage a network or web of stakeholder interests across organizational boundaries and acknowledge a responsibility and duty towards not only toward shareholders, but also to other stakeholders such as local communities, governments, and interest groups. Corporations operate at the center of a "network of interrelated stakeholders that create, sustain and enhance value creating capacity (Jamali, 2008, p.219).”

As an eminent scholar in stakeholder theory, Freeman (2010) argued that

Business can be understood as a set of relationships among groups which have a stake in the activities that make up the business. Business is about how customers, suppliers, employees, financiers..., communities and managers interact and create value. To understand a business is to know how these relationships work (p. 7).

Business organizations may be influenced in their engagement of corporate social responsibility initiatives by many different types of stakeholders, including shareholders, employees, interest groups, consumers and institutionally-based stakeholders, such as 
government and communities (Brammer et al., 2007; Dimaggio \& Powell, 1991; Doh \& Guay, 2006; Tolbert \& Zucker, 1996).

Five themes are common in studies based on stakeholder theory: (a) stakeholder identification and salience; (b) stakeholder actions and responses; (c) firm actions and responses, including how firms gain stakeholder support and balance stakeholder interest; (d) firm performance, particularly with respect to financial and other organizational outcomes; and (e) theory debates (Laplume et al., 2008). Of these, stakeholder identification, stakeholder salience, and firm performance are of wide interest in the literature. In a widely cited article, Mitchell et al., (1997) proposed a theory of stakeholder identification and stakeholder salience based on what were described as three empirically testable attributes: power, legitimacy and urgency. Several types of stakeholders were hypothesized including (a) definitive stakeholders who possess all three attributes; (b) dominant, dangerous, or dependent stakeholders who possess two of the three attributes; and (c) dormant, discretionary, or demanding stakeholders who possess only one attribute (Mitchell et al., 1997).

Donaldson and Preston (1995) argued that stakeholder theory investigations should incorporate descriptive accuracy, instrumental power, and normative validity. Descriptive accuracy attempts to explain or predict specific corporate characteristics and behaviors such as the nature of the firm, how managers think about managing, and how board members think about the interests of corporate constituencies, while instrumental power seeks to identify connections between stakeholder management and specific corporate objectives such as profitability and growth. A normative perspective is 
prescriptive in nature regarding the moral guidelines for the operating and management of a business.

Stakeholder theory has been critiqued mainly in comparison to the view that shareholder value maximization is the primary purpose of the corporation. In the shareholder value maximization theory, the assumption is that business organizations are responsible to shareholders who are, or should be, the primary and only stakeholders of concern. Criticisms of stakeholder theory include arguments that corporate governance becomes more complicated (Sudaram \& Inkpen, 2004); entrepreneurial risk taking is impeded (Sudaram \& Inkpen, 2004); resources of the firm may be misused by special interests (Jensen, 2002); and accountability and private property are undermined (E. Sternberg, 1997).

Sundaram \& Inkpen (2004) illustrated, however, that there was a cyclical timebased nature to the dominance of shareholder or stakeholder perspective in the management literature, frequently driven by the nature of government intervention or political policies at the time (Sudaram \& Inkpen, 2004). In other words, there have been times when stakeholder theory was a preferential model in comparison to shareholder maximization and vice versa.

\section{Summary of Empirical Research on CSR and Stakeholder Management}

A large portion of the literature focused on empirical research studies of corporate social responsibility has investigated whether there are strategic or financial advantages for corporations to engage in socially responsible behavior. Results have been mixed, 
with some studies showing a positive association between firm financial performance and corporate social responsibility, while others have shown limited or no relationship.

In an empirical study of the relationship between stakeholder management models and firm financial performance, Berman, et al. (1999) found that some stakeholder relationships had both direct and indirect effects on firm financial performance and that “...interaction $<$ effects $>$ suggest that the connections among stakeholder relationships, strategy and financial performance are fairly complex (p. 500)." Many of the studies reported results that showed limited direct linkages between corporate social responsibility and financial performance (Abbott, Walter \& Monsen, 1979; Balcom \& Rawlins, 2010; Blowfield, 2005; Brammer et al., 2007; De-los-Angeles Gil-Estallo, Giner-de-la-Fuente, \& Griful-Miquela, 2009; Garcia-Castro, Arino, \& Canela, 2010; Gauthier, 2005; Gjolberg, 2009; Gond \& Crane, 2008; Murillo \& Lozano, 2006; Peloza, 2009; Poddi \& Vergalli, 2009; Turker, 2009). A recent study by Baron et al. (2008), however, suggested that more engagement in corporate social responsibility was associated with better financial performance.

Other research has shown that corporate social responsibility may be related to corporate performance through strategic factors such as improvements in customer relations, corporate reputation, and employee satisfaction and retention (Balcom \& Rawlins, 2010; Brammer et al., 2007; Gauthier, 2005; Gjolberg, 2009; Luo \& Bhattacharya, 2006; Poddi \& Vergalli, 2009; Turker, 2009).

Factor relationship investigations of corporate social responsibility have not been as widely studied, although various types of factors have been investigated. Research 
studies have included factors such as financial performance, top management intentions, consumer orientation, firm strategic diversification efforts, asset age, culture, leadership values and behavior, institutional and strategic effects, industry impacts, board diversity, managerial control, market share, geography, and size of company (Baughn, Bodie, \& Mcintosh, 2007; Coffey \& Wang, 1998; Cottrill, 1990; Lerner \& Fryxell, 1988; Mcguire, Sundgren, \& Schneeweis, 1988; Übius \& Alas, 2009; Waldman, Siegel, \& Javidan, 2006; Waldman, Sully de Luque, et al., 2006). A substantial issue in many of the studies was what measures to use to determine level of engagement in corporate social responsibility. Although not an exhaustive selection, several studies are reviewed below to show the breadth of factors studied and the different ways that corporate social responsibility was measured.

Lerner and Fryxell's (1988) study of determinants of corporate social responsibility included several financial performance variables, company growth rate, the number of employees in the firm, type of industry, advertising intensity, propensity of the business to acquire other firms, and asset age. The authors argued that finding significant explanatory variables depended on how corporate social responsibility was measured, illustrated through a research model of three different measures of corporate social responsibility: (a) corporate social responsibility indexed by amount of philanthropy and disclosure of social initiatives; (b) corporate social responsiveness indexed by the number of women and minorities on the board of directors and in top management; and (c) position on social issues as measured by involvement in business operations in South Africa, military involvement and contributions to Political Action Committees (PACs). 
Results varied for the measures with company size and type of industry significantly related to the corporate responsibility while financial performance, propensity to acquire and firm size were significantly related to corporate responsiveness. The authors concluded that future studies need more specificity in measuring corporate social responsibility and should take into consideration the firm's industry as social pressures and constraints vary by industry (Lerner \& Fryxell, 1988). Industry effects, including intra-industry and firm market power were found to be significantly associated with corporate social responsibility in a study that used reputation ratings from Fortune as a proxy for measuring level of corporate social responsibility engagement (Cottrill, 1990). Several studies investigated the relationship of corporate social responsibility with leadership, managerial control, and culture. Board member diversity and the percentage of stock ownership by insiders, representing managerial control, were found to be significantly associated with corporate philanthropy used as a measure for corporate social responsibility engagement (Coffey \& Wang, 1998).

In two other studies based on investigational factors of organizational attributes and managerial values, the transformational leadership theory component of CEO intellectual stimulation was found to be significantly related to strategic corporate social responsibility (Waldman, Siegel, et al., 2006) and organizational structure was found to be significantly associated with corporate social responsibility performance and respect for stakeholder interests Übius \& Alas (2009).

Country attributes related to corporate social responsibility engagement were investigated in a study of fifteen Asian countries, that showed wide variation in the 
practice of corporate social responsibility across countries (Baughn et al., 2007). Country factors included in the study were per capita gross domestic product (GDP), country distribution of income as measured by the Gini index, and levels of economic freedom, political and civil liberties, perceived corruption and country integration with the global economy. Corporate social responsibility was divided into social and environmental CSR and was measured using a scale developed from several survey items from the Executive Opinion Survey, a component of The Global Competitiveness Report. ${ }^{5}$ Economic freedom, per capita GDP, political freedom and low levels of corruption were significantly related to both social and environmental corporate social responsibility.

The literature on stakeholder theory as related to corporate social responsibility and corporate strategic-decision making is fairly sparse and potential exists for expansion, including broader use of different types of research methodologies. Winn (2001) argued that, although there have been advances in the broad field of corporate social responsibility and stakeholder theory, the field remains in its infancy, particularly for studies on strategic decision making related to corporate social responsibility and stakeholders. Investigations studying stakeholder theory and decision-making were found in many different disciplines, including corporate social responsibility, urban models, opinion dynamics, consumer behavior, industrial networks, supply chain management, flow analysis, and market and organizational analysis (Bonabeau, 2002; Gilbert, 2008). Several relevant studies are reviewed below.

\footnotetext{
${ }^{5}$ Source: $\underline{\text { https://wefsurvey.org/index.php?sid }=28226 \& \text { intro }=0}$
} 
In a study merging resource dependence theory and stakeholder theory, case study methodology was used to investigate the types of influence strategies available to stakeholders and the determinants of the type of influence a stakeholder would choose to use (Frooman, 1999). Based on a conflict between Starkist ${ }^{\circ}$ and EII, an environmental advocacy organization, four types of influence strategies were hypothesized: direct withholding, direct usage, indirect withholding and indirect usage. The influence strategies proposed were based on resource dependence theory power concepts and the opportunity for stakeholders to gain control over firm resources. Frooman (1999) argued that, although traditional stakeholder theory focused on dyadic one-way relationships of stakeholders to the firm, stakeholders also take actions on the firm and tend to interact with each other both directly and indirectly. Strategic actions and decisions by managers “...presupposes that they have some idea of how others <stakeholders> in their environment will act (Frooman, 1999, p. 203)." Resource dependence theory is based on the assumption that organizations or other types of entities attempt to influence other entities through control of needed resources in an effort to reduce environmental interdependence and uncertainty (Pfeffer \& Salancik, 1978). A review article on resource dependence theory, suggested that stakeholder theory is a constructive frame of reference for resource dependence theory (RDT) due to the coexistence of multiple dependencies among stakeholders that affects strategic use of resources and decision-making (Hillman, Withers, \& Collins, 2009).

A theoretical model of decision-making was proposed by Puncheva (2008) that used exchange rules between the firm and stakeholders that governed the decision- 
making process and included corporate reputation, social legitimacy, pragmatic legitimacy and exchange benefits were included. Management decision-making frameworks based on compliance, strategy and force were studied to determine the impacts on strategic decision-making with respect to corporate social responsibility in a case study investigation of four major corporations (Munilla \& Miles, 2005).

Cultural dimensions of institutional collectivism and power distance as predictors of the social responsibility values of top management, with the assumption that such values guide managerial decision-making with respect to corporate social responsibility practices were investigated in a fifteen country longitudinal study (Waldman, Sully de Luque, et al., 2006). Consistent with the theory and practice of stakeholder management, the authors argued that corporate social responsibility engagement was multidimensional, composed of concern for shareholders and owners, other stakeholders, and community/state welfare. The investigation showed that managers in wealthier countries tended to be more focused on shareholders and owners, tending to leave societal concerns to government or other institutions, in contrast to managers in poorer countries. The authors surmised that the latter may "feel more of a personal responsibility toward the community and society at large, especially as governmental institutions or other agencies in such countries may be less able to deal with these concerns (Waldman, Sully de Luque, et al., 2006, p. 834).” 


\section{Chapter 3}

\section{Research Design and Methods}

Business organizations are increasingly expected to pursue transparent socially responsible and socially responsive behavior and to respond to a variety of stakeholder groups that may include shareholders, employees, interest groups, consumers, civil society, governmental entities, and others (Brammer et al., 2007; Margolis \& Walsh, 2003). With this increasing pressure, the fundamental research question for this study was whether variation exists in the levels of engagement in sustainability efforts across firms, and, more importantly, why such variation exists. Stakeholders have been identified as potential influencers impacting a firm's strategic decisions to engage in sustainability (Brammer et al., 2007; Freeman, 2010; Frooman \& Murrell, 2005; Frooman, 1999; Hendry, 2005; Quattrone \& Tversky, 1988). This study sought to determine whether relevant stakeholders were important influencers in firm engagement in sustainability and whether other relevant contextual influences positively or negatively impacted firm engagement in sustainability or were important control factors for the influences of stakeholders.

The research study was based on deductive reasoning and used quantitative methods in a multivariate investigation. The study included a sample size of 400 business organizations in twenty-five countries. The study was based on the assumptions that firms make intentional decisions on whether or not to engage in sustainability, and/or how much to engage in sustainability initiatives. Influence factors on business organizations (the "firm") were investigated as determinants of a firm's engagement in 
sustainability and fell into two broad categories: stakeholder influencers and contextual influences.

\section{Stakeholders as Influencers}

Stakeholders are considered to be individuals, groups and/or relationships that have an interest in a firm, whether or not the firm has a corresponding interest in the stakeholders, with the presumption that the interests of all stakeholders have intrinsic value (Donaldson \& Preston, 1995; Freeman, 1984; Freeman, 2010; Freeman et al., 2013; Mitchell, Agle, \& Wood, 1997)." A major assumption of stakeholder theory is that organizations manage stakeholder interests across organizational boundaries, and seek to identify, and in some cases, act on, connections between stakeholders and specific corporate objectives (Donaldson \& Preston, 1995). Stakeholders have been theorized to influence organizations through various strategies and mechanisms such as power availability and the opportunity for stakeholders to gain control over firm resources (Frooman \& Murrell, 2005; Frooman, 1999; Hendry, 2005).

Although there are potentially many stakeholder types that may influence a firm, three stakeholder types were chosen for the investigation due to their assumed salience and relevance to sustainability efforts by a firm: executive management, community, and government. Mitchell et al. (1997) argued that stakeholders should meet at least one of three attributes of power, legitimacy and/or urgency. Power sources may be defined as reward, coercive, legitimate, referent and expert (French \& Raven, 2006). Reward power is based the ability of the influencer to reward; coercive power is based on punishment if there is failure to conform to the influence expectation; legitimate power, also known as 
authoritative power, stems from norms that the influencer has a legitimate right to influence; referent power is based on conforming to the expected norms of the influencer; and expert power relies on the perception of expertise of the influencer (French \& Raven, 2006).

Each of the stakeholder types chosen have the potential for both power and legitimacy as stakeholders in influencing firm engagement in sustainability and were screened for relevancy to sustainability as the strategic issue at stake. Executive managers have access as stakeholders through multiple sources of power, including legitimate, reward, and coercive power, and in their roles in the company have legitimacy to act on behalf of the firm in influencing strategic decisions. Communities are informal institutions that have access to referent and coercive power and legitimacy to influence firms as stakeholders through norms and expectations of social behavior. Governments are formal institutions with access to power and legitimacy to influence as stakeholders through coercive means such as regulatory requirements or through reward power such as providing incentives such as subsidies for firms to engage in sustainability. Testing the strength of stakeholder theory as related to the ability of stakeholders to influence major corporate decisions was a major goal of this portion of the investigation.

\section{Contextual Factors as Influencers}

Contextual factors, such as social, cultural, political, economic, technological, labor, industry and demographic forces, are attributes that a firm may take into consideration when making strategic decisions (David, 2011; Mayo \& Nohria, 2005; Parnell, 2014). Several contextual factors were chosen for the investigation as relevant to 
sustainability challenges. Firm-related factors investigated the impact or influence the factor had on firm engagement in sustainability and included firm size, firm financial performance, and industry sector. Country-related factors studied were country technological readiness, country dependence on fossil fuels, and country economy and stage of economic development. Country-related factors were based on data for the country in which the firm had its headquarters offices.

\section{Empirical Setting and Unit of Analysis}

The empirical setting was composed of a population of large, publicly listed business firms from around the globe. The large, publicly list business organization was chosen as the unit of analysis for ease of access to firm information as a public entity and because large firms potentially have a substantial global impact in the area of sustainability. ${ }^{6}$

Population data were obtained from the list of companies that were invited to participate in the 2011 Dow Jones Sustainability Index (DJSI)/RobecoSAM ${ }^{7}$ Corporate Sustainability Assessment (CSA) ${ }^{8}$ The criteria for inclusion in the DJSI list was based on the firm's ranking as one of the world's largest companies, using the Dow Jones Total Stock Market Index free float capitalization as the main criterion. The top $15 \%$ of the companies on the list earned inclusion in The Sustainability Yearbook ${ }^{9}$ as sustainability

\footnotetext{
${ }^{6}$ G. Scott Thomas, http://www.bizjournals.com/bizjournals/on-numbers/scott-thomas/2012/07/16055companies-fit-the-definition-of.html?page=all, July 27, 2012.

${ }^{7}$ http://www.robecosam.com/

${ }^{8}$ Source: http://www.sustainability-index.com/review/annual-review-2012.jsp

${ }^{9}$ Description of The Sustainability Yearbook 2011: "The Sustainability Yearbook is one of the world's most comprehensive annual publications on sustainability trends and corporate sustainability performance covering 58 industry sectors. Only the top $15 \%$ in each of the 58 SAM sectors qualify for inclusion in The Sustainability Yearbook. The best companies from each sector are named "SAM Sector Leaders". Those
} 
leaders based on the rankings of the company CSAs. ${ }^{10}$ The remaining $85 \%$ of the companies either chose not to participate or were not considered sustainability leaders based on the results of their CSAs. The population for the current study included the entire DJSI eligible list of companies, without considering whether a company was identified as a sustainability leader.

The DJSI list includes a primary country location and an industry sector for each company. Industry sectors are based on the Global Industry Classification System (GICS) and are identified as SAM SuperSectors and SAM Sectors in the DJSI list. ${ }^{11}$ In the 2011 DJSI list, there were fifty-eight SAM Sectors that were further rolled up into one of nineteen SAM SuperSectors (see Appendix A). For the current study, an adjustment was made to the DJSI list to eliminate companies whose primary business activities were tobacco or gambling based on industry sector classification. ${ }^{12}$ The final population used for obtaining the sample set was composed of 3,078 firms.

\section{Sample Set}

Fifty-one countries were represented in the 2011 DJSI list, representing a total of 3,078 firms in the population. Appendix B gives the breakdown of the number of firms in each country in the 2011 DJSI list.

\footnotetext{
firms from each sector that have shown the greatest relative improvement in their sustainability performance are given the distinction of "SAM Sector Mover,", http://www.robecosam.com/en/sustainability-insights/library/the-sustainability-yearbook.jsp, p.36. ${ }^{10}$ Source: The Sustainability Yearbook 2011, SAM (member of Robeco) in cooperation with PricewaterhouseCoopers (PwC), http://www.robecosam.com/en/sustainability-insights/library/thesustainability-yearbook.jsp, pp. 36, 46.

${ }^{11}$ Source: http://www.sustainability-index.com/review/annual-review-2012.jsp; http://www.sustainabilityindices.com/images/130912-djsi-review-2013-en-vdef_tcm1071-372482.pdf

12 Note: Companies for which tobacco and gambling are the primary business activity were eliminated for this project, consistent with ethical and socially responsible investment reasoning.
} 
Because this investigation used several country-related influence factors to test, an initial screening of the population data was performed to determine that there was an adequate sampling of firms in each country in the study. Two screening cut-offs were performed: (a) countries having at least twenty firms in the 2011 DJSI list and (b) countries having at least twenty-five firms in the 2011 DJSI list. The latter did not yield a representative sampling of countries globally. Particularly lacking was a large enough representative sampling of firms in developing countries.

Countries with at least twenty companies in the DJSI list yielded a population of twenty-five countries and 2,895 firms (Appendix B). The twenty-five countries represented developed and developing economies and included companies from each of the major regions of the world, except for the Middle East. Countries from North America, South America, Africa, Asia, and Australia were included in the sample set (see Appendix B).

A sample set size of four-hundred cases was chosen, which represented thirteen percent of the total population of 3,078 firms. Using random number generation from www.random.org, sixteen firms were randomly chosen among the firms listed for each of the twenty-five countries to obtain the sample set of four-hundred cases. 


\section{Hypotheses and Measurement Models}

The research question was to determine whether stakeholders and contextual factors influence a firm's major strategic decisions, particularly for those decisions that have broad impact outside of the firm itself. A firm's decisions regarding engagement levels in sustainability ("firm engagement in sustainability") was chosen to represent this type of major strategic decision as the dependent variable.

The main hypothesis was developed to test a generalized model of relationships between stakeholders, contextual factors and the influence on a firm's major strategic decisions with respect to sustainability engagement.

H1. Stakeholder influencers and contextual influences related to the firm and the country in which the firm has its headquarters impact the firm's major strategic decisions with respect to sustainability engagement.

Figures 1 and 2 graphically depict the proposed relationships. Additional hypotheses for each of the individual influence factors were also developed and are discussed in the section on independent variables. The measurement and analysis model was organized in a manner that allowed investigation of individual influence factors as independent variables, while also testing for the main hypothesis. 


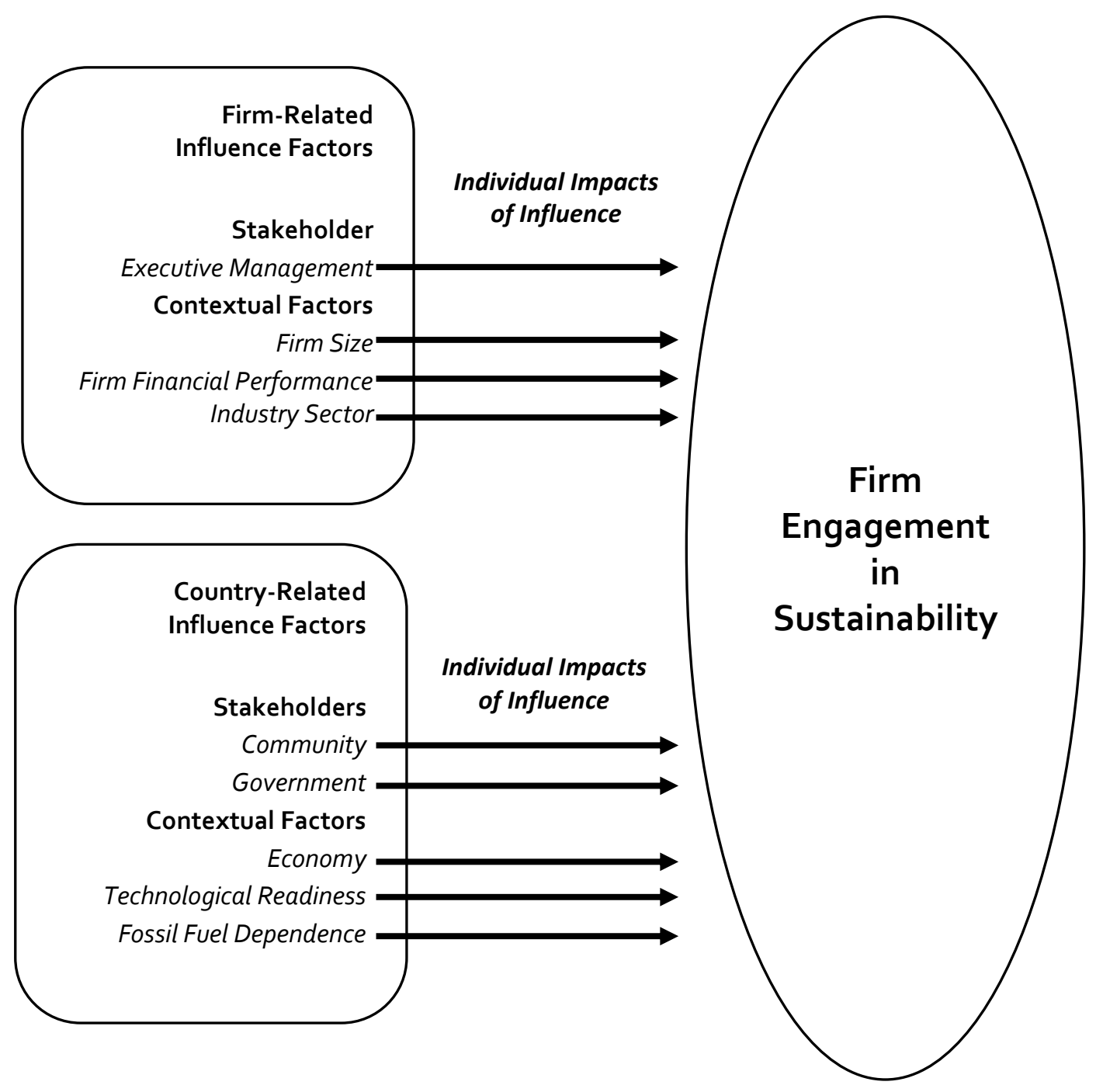

Figure 1. Illustration of Proposed Relationships Between Individual Influence Factors and Firm Engagement in Sustainability 


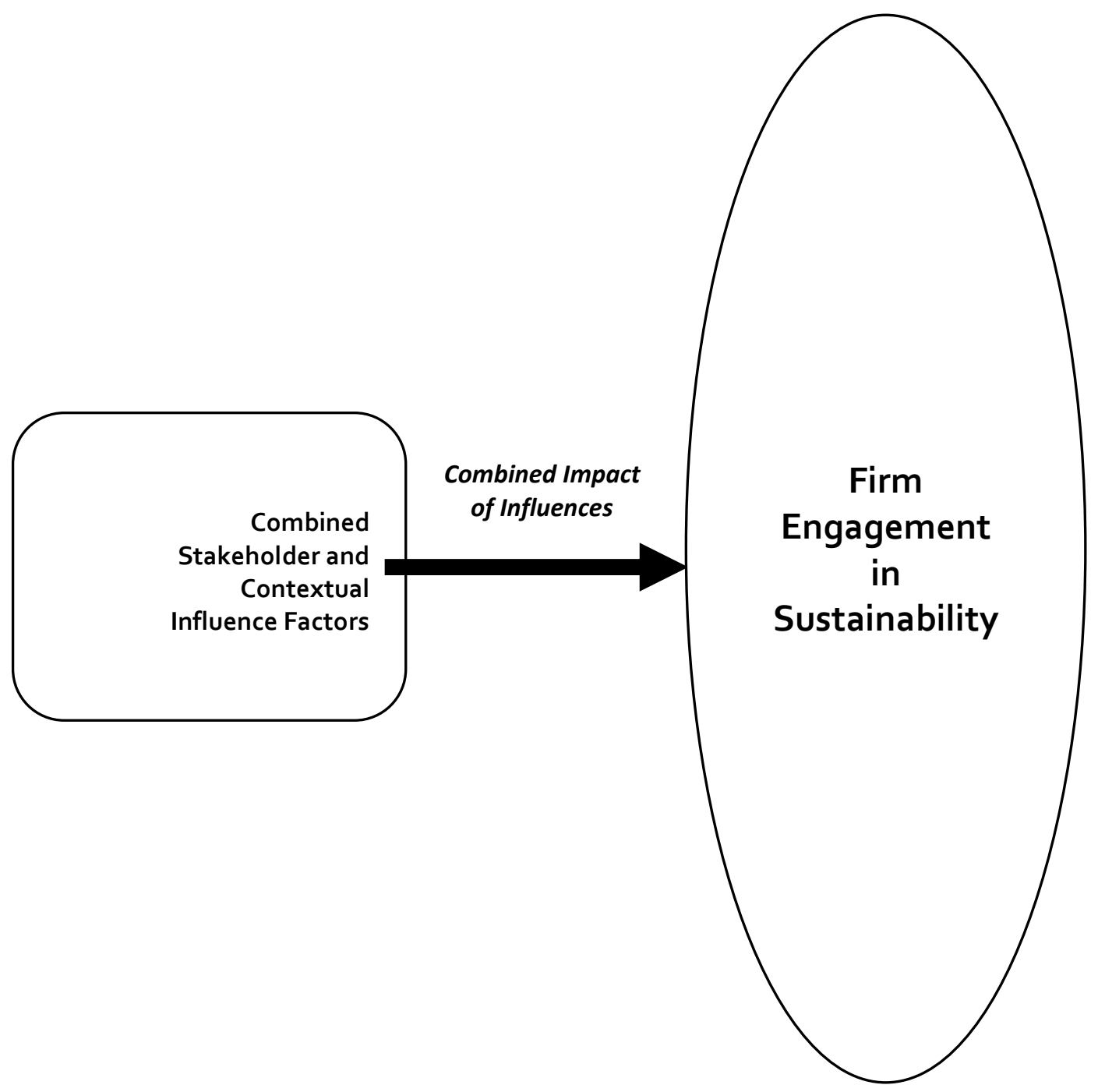

Figure 2. Illustration of Proposed Relationships Between Combined Influence Factors and Firm Engagement in Sustainability 


\section{Dependent Variable}

Firm engagement in sustainability may be considered a strategic initiative of corporate social responsibility by business organizations that includes responsible environmental and social practices (Brammer et al., 2007; Quattrone \& Tversky, 1988) and "actions taken by the firm intended to further social goods beyond the direct interests of the firm and that which is required by law (Doh \& Guay, 2006, p. 47; McWilliams \& Siegel, 2001)." For this study, the dependent variable was defined as firm engagement in sustainability, assumed to be the outcomes of major strategic decisions that a firm makes with respect to engaging in sustainability initiatives.

The impact of the influences on firm engagement in sustainability was measured using Environmental/Social/Governance (ESG) disclosure scores obtained from Bloomberg. Higher ESG disclosure scores broadly indicate more involvement in sustainability activities. For this study, it was assumed that if there was a significant association of the influence factor with ESG disclosure scores, then the factor was considered to have an impact through its influence on decisions regarding sustainability.

ESG disclosure scores obtained from Bloomberg are based on Bloomberg's assessment of a firm's valuation risk associated with extra-financial measures in the areas of environmental, social and governance practices including resource efficiency, emissions management, community relations, workforce development and board/committee structures (Bloomberg, 2013). ${ }^{13}$ As a source of financial and other information, Bloomberg tends to be comprehensive and reliable and provides access to

\footnotetext{
${ }^{13}$ Information retrieved through Bloomberg terminal, April 28, 2013.
} 
many companies globally. For example, for fiscal year 2011 Bloomberg had ESG data available for 5,217 companies around the world. ${ }^{14}$ Appendix $\mathrm{C}$ gives a brief description of Bloomberg's methodology for ESG disclosure scores and an example of firm ESG data.

ESG disclosure scores from Bloomberg were chosen for this study as the most reliable and comprehensive measure for impact on sustainability decision-making, after considerable research into other available measures. Measurement of firm engagement in sustainability, as related to corporate social responsibility behavior, is generally difficult and the availability of direct data is limited. The most common measures for evaluating corporate socially responsible behavior have been reputation indices; individual indicators such as air pollution measures; content analysis of corporate publications; socially responsible certifications such as ISO certifications; sustainability indices such as the Dow Jones Sustainability World Index, the Domini 400 Social Index, and ESG disclosure scores; and sustainability reports based on emergent standards such as the Global Reporting Initiative (GRI) and the United Nations Global Compact (UNGC) methodologies. (Baron et al., 2008; Poddi \& Vergalli, 2009; Turker, 2009).

Most data sources for measuring sustainability (or corporate social responsibility generally) have substantial limitations. For example, although many firms are currently issuing annual or routine GRI or UNGC sustainability reports, using data directly from these sources for measuring sustainability performance is limited. Although GRI and UNGC are emerging as comprehensive sustainability reporting standards, criticisms

\footnotetext{
${ }^{14}$ Source: http://www.bloomberg.com/bsustainable/\#report_2011_6
} 
include the lack of unified social reporting field standards, poor comparability of data across companies, and inconsistency in quality and consistency of company-reported data (Brown, de Jong, \& Levy, 2009; GRI, 2011). As another example, the Dow Jones Sustainability Index (DJSI) evaluates firms on a variety of sustainability measures each year and awards top performing sustainability companies with recognition as sustainability leaders, however, except for sustainability leaders, individual sustainability ratings of companies are not available. Other data sources such as LEED or ISO9000 certifications or company-published factors such as a company's annual level of philanthropic spending, are limited by inconsistency, lack of information availability and/or company bias. The limitations of Bloomberg ESG disclosure scores include many of these criticisms. The advantages of using Bloomberg ESG disclosure scores, however, are that data are available for many companies worldwide in a consistent framework based on broad sustainability factors and the data are vetted and analyzed by Bloomberg analysts which may serve to reduce company bias, even though much of the data are obtained from company materials.

An initial screening showed that there were substantial differences in the levels of sustainability across firms, as measured by ESG disclosure scores. Variation in the levels of firm sustainability engagement was determined empirically through observation that the range of environmental/social/governance (ESG) disclosure scores across the four hundred firms from twenty-five countries in the study was substantial. ${ }^{15}$ ESG disclosure scores generally range from 0 to 100 and for the sample set the range was 0 to 89 . As

\footnotetext{
${ }^{15}$ See Research Design section
} 
representative of firm level of sustainability, ESG disclosure scores are limited since they are partially computed from firm self-reported data. However, pressures for business organizations to be transparent regarding their sustainability efforts and the granular data that is used to calculate ESG disclosure scores lends weight to the measure. The empirical variation shown by the range of ESG disclosure scores for the firms in the sample set confirms anecdotal observations that firms engage in sustainability initiatives at differing levels. Descriptive statistics of firm engagement in sustainability for the firms in the sample set are shown in Table 1.

\section{Table 1}

Descriptive Statistics of Firm Engagement in Sustainability for Firms in Sample Set as Measured by FY2011 ESG Disclosure Scores

\begin{tabular}{lccccc}
\hline & Mean & $\begin{array}{c}\text { Standard } \\
\text { Deviation }\end{array}$ & Minimum & Maximum & N \\
\hline FY2011 ESG & 30.95 & 18.64 & 0.00 & 88.84 & 400 \\
Disclosure Scores & 300 & & \\
\hline
\end{tabular}

Note: ESG disclosure score data retrieved from Bloomberg, www.bloomberg.com 


\section{Independent Variables}

Factors that influence firm engagement in sustainability were defined along two axes: (a) as influence factors that were either stakeholder influencers or contextual influences and (b) as influence factors that were company-related or country-related (see Figure 3). Each independent variable, therefore, was assigned as either a stakeholder influencer or a contextual influence, and as either firm-related or country-related. Country-related factors were associated with the country in which a firm has its main headquarters.

This section is organized as follows. Firm-related stakeholder influencer(s) are considered first followed by firm-related contextual influences. Country-related influence factors are then considered using the same format. A description of each influence factor is followed by a hypothesis related to the influence factor and an explanation of the measure(s) used to test the hypothesis. 


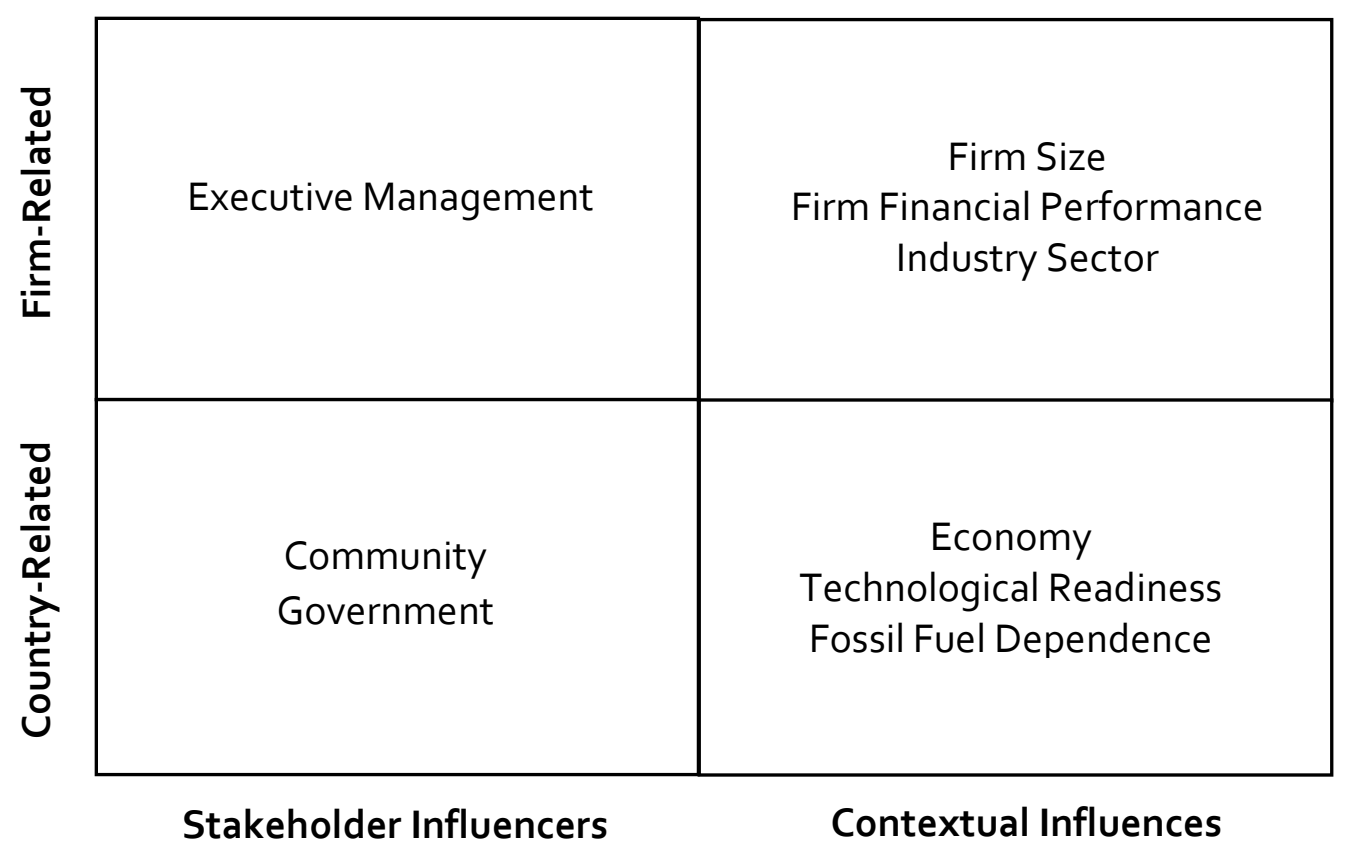

Figure 3. Influence Factors Matrix 


\section{Firm-Related Influence Factors}

Firm-related influence factors were those factors directly associated with the firm in some manner. Executive management was investigated as a firm-related stakeholder influence factor and firm size, firm financial performance and industry classification were investigated as contextual influence factors. In this section, each factor is described along with the hypothesis associated with the factor and the measure(s) used to test the hypothesis. Figure 4 is a graphical illustration of the hypotheses and measurement models for the firm-related influence factors. 


\section{Main Hypothesis}

$\mathrm{H}_{1}$. Stakeholder influencers and contextual influences related to the firm and the country in which the firm has its headquarters impact the firm's major strategic decisions with respect to sustainabilitv enaagement.

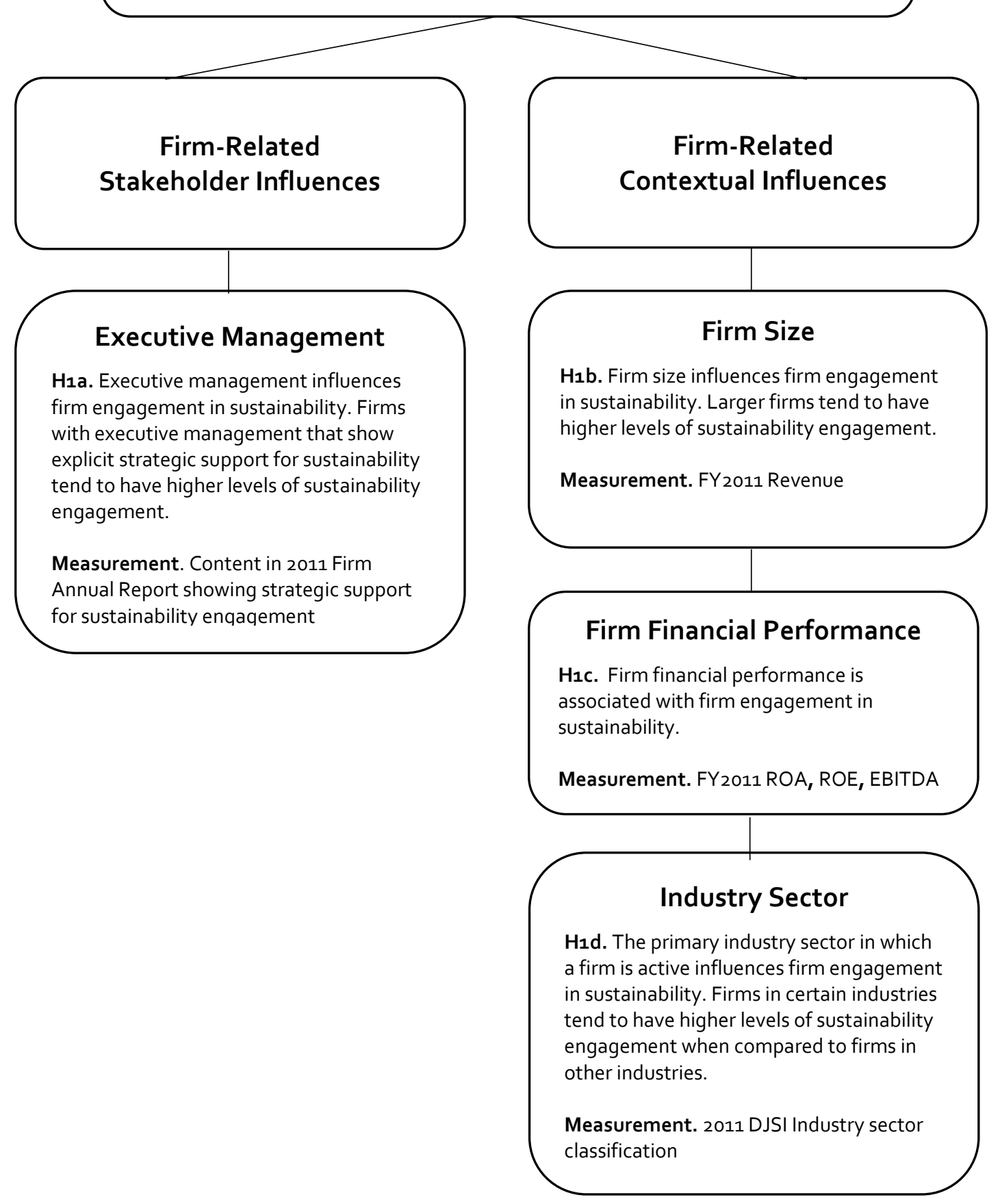

Figure 4. Firm-Related Influence Factors: Hypotheses and Measurement Models 


\section{Executive Management as Stakeholder Influence Factor}

Several studies on management showed significant association between managerial and leadership values and corporate social responsibility with arguments that the values were complex and broadly concerned with responsiveness toward other stakeholders. (Übius \& Alas, 2009; Waldman, Siegel, et al., 2006; Waldman, Sully de Luque, et al., 2006). The current study sought to determine whether support for sustainability as an explicit component of company strategy by the firm's top management was an influence factor that was associated with firm engagement in sustainability. Executive management was considered to include the Chairman, the Chief Executive Officer and/or other executive managers who were the primary authors of the firm's strategy disclosed in the firm's annual report.

\section{Hypothesis}

H1a. Executive management influences firm engagement in sustainability. Firms with executive management that shows explicit strategic support for sustainability tend to have higher levels of sustainability engagement.

\section{Measurement}

Executive management's support for sustainability as an explicit component of firm strategy was measured by determining whether the firm strategy included sustainability content in the firm's 2011 annual report. A simple coding schema was used as shown in Table 2. Discussion about sustainability in the annual report was measured as 
a determinant of management's positive view of sustainability as a strategic component of the company.

Table 2

Executive Management Stakeholder Influence Indication as Measured by Content in FY2011 Annual Report Showing Strategic Support for Sustainability

Executive Management Stakeholder Influence Indication
Project

Code
$\mathbf{N}$

0

100

No mention of sustainability, corporate social responsibility or other activities that could be perceived as sustainability or otherwise related to corporate social responsibility.

Some mention of sustainability, corporate social responsibility or other activities that could be perceived as sustainability or otherwise related to corporate social responsibility. Typically found in Letter to Shareholders, although sometimes embedded in the business strategy section of the management report section of the annual report.

Extensive discussion of sustainability, corporate social responsibility or other activities that could be perceived as sustainability or otherwise related to corporate social responsibility. Usually, for this coding, a separate, extensive chapter on sustainability or corporate social responsibility was included in the report.
1

54

2 246 


\section{Firm Size as Contextual Influence Factor}

Firm size was found to be significantly related to corporate social responsibility in a study by Lerner \& Fryxell (1988). Larger companies tend to have greater resources, including capital and human resources, and may also be more visible as targets for stakeholder pressures and influences.

\section{Hypothesis}

H1b. Firm size influences firm engagement in sustainability. Larger firms tend to have higher levels of sustainability engagement.

\section{Measurement}

Firm size was measured by FY2011 revenue data obtained from Bloomberg and Mergent Online databases. ${ }^{16,17}$ All data was obtained in US dollars, using the currency conversion applications in the databases. Table 3 shows the descriptive statistics of 2011 revenue (USD) for firms in the sample set.

The number of employees or size of workforce was also initially considered as representative of the size of the firm, however, it was removed for several reasons because the quality of the data for size of workforce was difficult to ascertain and, frequently, the number of employees was not reported in public documents. Size of workforce may also include contract workers, seasonal workers, or other workers not

\footnotetext{
${ }^{16}$ Bloomberg L.P., www.bloomberg.com, is a privately held financial software, data and media company headquartered in New York City. Bloomberg L.P. provides financial software tools including financial information on publicly traded companies globally. Data was accessed through Bloomberg terminals at University of Portland.

${ }^{17}$ Mergent, Inc., www.mergent.com, is a leading provider of global business and financial information on publicly traded companies. Data accessed through Mergent Online database at George Fox University library.
} 
considered FTEs --data that is difficult to obtain. It was thus decided that revenue would be used as a sufficient measure of firm size.

Table 3

Descriptive Statistics of Firm Size for Firms in Sample Set as Measured by 2011 Revenue (USD Billions)

\begin{tabular}{lccccc}
\hline & Mean & $\begin{array}{c}\text { Standard } \\
\text { Deviation }\end{array}$ & Minimum & Maximum & N \\
\hline $\begin{array}{l}\text { FY2011 Revenue } \\
\text { (USD Billions) }\end{array}$ & 14.98 & 28.05 & 0.09 & 297.04 & 400 \\
& & & & & \\
\hline
\end{tabular}

Note: Revenue data retrieved from Mergent Online, www.mergent.com; and Bloomberg, www.bloomberg.com 


\section{Firm Financial Performance as Contextual Influence Factor}

Previous studies have shown mixed results regarding the association of financial performance with corporate social responsibility. Some studies found that CSR was linked to strategic or financial advantages of a firm (Baron et al., 2008; Berman et al., 1999; Lerner \& Fryxell, 1988), while others did not find the same association or showed limited direct linkages between corporate social responsibility and financial performance (Abbott, Walter \& Monsen, 1979; Balcom \& Rawlins, 2010; Blowfield, 2005; Brammer et al., 2007; De-los-Angeles Gil-Estallo et al., 2009; Garcia-Castro et al., 2010; Gauthier, 2005; Gjolberg, 2009; Gond \& Crane, 2008; Murillo \& Lozano, 2006; Peloza, 2009; Poddi \& Vergalli, 2009; Turker, 2009). The intent for this investigation was to ascertain whether any association existed, either positive or negative, between financial performance and firm engagement in sustainability.

\section{Hypothesis}

H1c. Firm financial performance influences firm engagement in sustainability.

\section{Measurement}

Financial performance was measured using three parameters: (a) return on assets (ROA); (b) return on equity (ROE); and (c) earnings before interest, taxes, depreciation and amortization (EBITDA). Data were obtained from Bloomberg and Mergent Online databases for fiscal year 2011. Table 4 shows the descriptive statistics of the 2011 financial performance parameters for the firms in the sample set. 
Table 4

Descriptive Statistics of Firm Financial Performance Parameters for Firms in Sample Set as Measured by ROA, ROE, and EBITDA (\%)

\begin{tabular}{lccccc}
\hline & Mean & $\begin{array}{c}\text { Standard } \\
\text { Deviation }\end{array}$ & Minimum & Maximum & N \\
\hline & & & & & \\
FY2011 ROA (\%) & 7.26 & 9.49 & -19.41 & 90.93 & 400 \\
FY2011 ROE (\%) & 17.47 & 21.66 & -68.44 & 177.10 & 400 \\
FY2011 EBITDA (\%) & 25.36 & 18.11 & -17.67 & 85.18 & 400 \\
\hline
\end{tabular}

Note: ROA, ROE and EBITDA data retrieved from Mergent Online, www.mergent.com; Bloomberg, www.bloomberg.com 


\section{Industry Sector as Contextual Influence Factor}

Cottrill's (1990) study showed that industry was a significant explanatory variable of corporate social responsibility, and Lerner \& Fryxell (1988) suggested that a firm's industry had an impact on the level of corporate social responsibility due to social pressure and constraint variation by industry. This investigation sought to determine only whether the primary industry sector in which a firm was actively engaged was associated with firm engagement in sustainability. The investigation did not include any study on the specific constraints or characteristics of the industry sectors.

\section{Hypothesis}

H1d. The primary industry sector in which a firm is active influences firm engagement in sustainability. Firms in certain industries tend to have higher levels of sustainability engagement when compared to firms in other industries.

\section{Measurement}

Industry sector was defined as the main industry in which a firm is engaged, as classified in the DJSI list of companies used as the population and from which the sample set was drawn. DJSI classes industry sectors based on the Global Industry Classification System (GICS). The sectors are segmented into nineteen SAM Supersectors, which were used as the measure for industry sector for this study. Project coding and the number of firms in each industry sector in the sample set are shown in Table 5. 
Table 5

Industry Sector Distribution of Firms in Sample Set as Measured by DJSI Industry Classification

\begin{tabular}{lcc}
\hline & Project Code & N \\
Industry Sector & & \\
\hline & 1 & 17 \\
Automobile \& Parts & 2 & 35 \\
Banks & 3 & 16 \\
Chemicals & 4 & 18 \\
Construction \& Materials & 5 & 17 \\
Financial Services & 6 & 33 \\
Food \& Beverage & 7 & 18 \\
Healthcare & 8 & 17 \\
Personal/Household Goods & 9 & 40 \\
Industrial Goods/Services & 10 & 10 \\
Insurance & 11 & 36 \\
Basic Materials & 12 & 13 \\
Media & 13 & 28 \\
Oil \& Gas & 14 & 17 \\
Real Estate & 15 & 14 \\
Retail & 16 & 12 \\
Technology & 17 & 16 \\
Telecommunications & 18 & 17 \\
Travel \& Leisure & 19 & 26 \\
Utilities & & \\
& & \\
\hline
\end{tabular}

Note: Industry sector classifications were based on DJSI SAM SuperSector classifications retrieved from The Dow Jones Sustainability World Index Guide, www.sustainability-index.com;

http://www.sustainability-index.com/review/annual-review-2012.jsp) 


\section{Country-Related Influence Factors}

A major assumption of this study was that the thrust, decision-making and determination of a firm's major sustainability strategic initiatives are organizationally situated in the headquarters office. Some research suggests that corporate social actions are often oriented toward the locales in which firm headquarters offices are located (Galaskiewicz, 1997; Guthrie, 2003; Kanter, 1997; McElroy \& Siegfried, 1986). Other studies have shown that there is country variation in the practices of corporate social responsibility (Baughn et al., 2007; Waldman, Sully de Luque, et al., 2006). For example, Waldman, Sully de Luque, et al. (2006) found that in wealthier countries, managers tended to be more focused on shareholders and owners, while leaving societal concerns to government or other institutions, in contrast to managers in poorer countries.

Country-specific influence factors were investigated with data gathered on the country in which a firm's headquarters offices were located. Community and government were investigated as country-related stakeholder influencers. The economy, technological readiness and fossil fuel dependence were investigated as contextual influences. Each factor is described below along with the minor hypothesis associated with the factor and the measure(s) used to test the hypothesis. Figure 5 is a graphical illustration of the hypotheses and measurement models for the firm-related influence factors. 


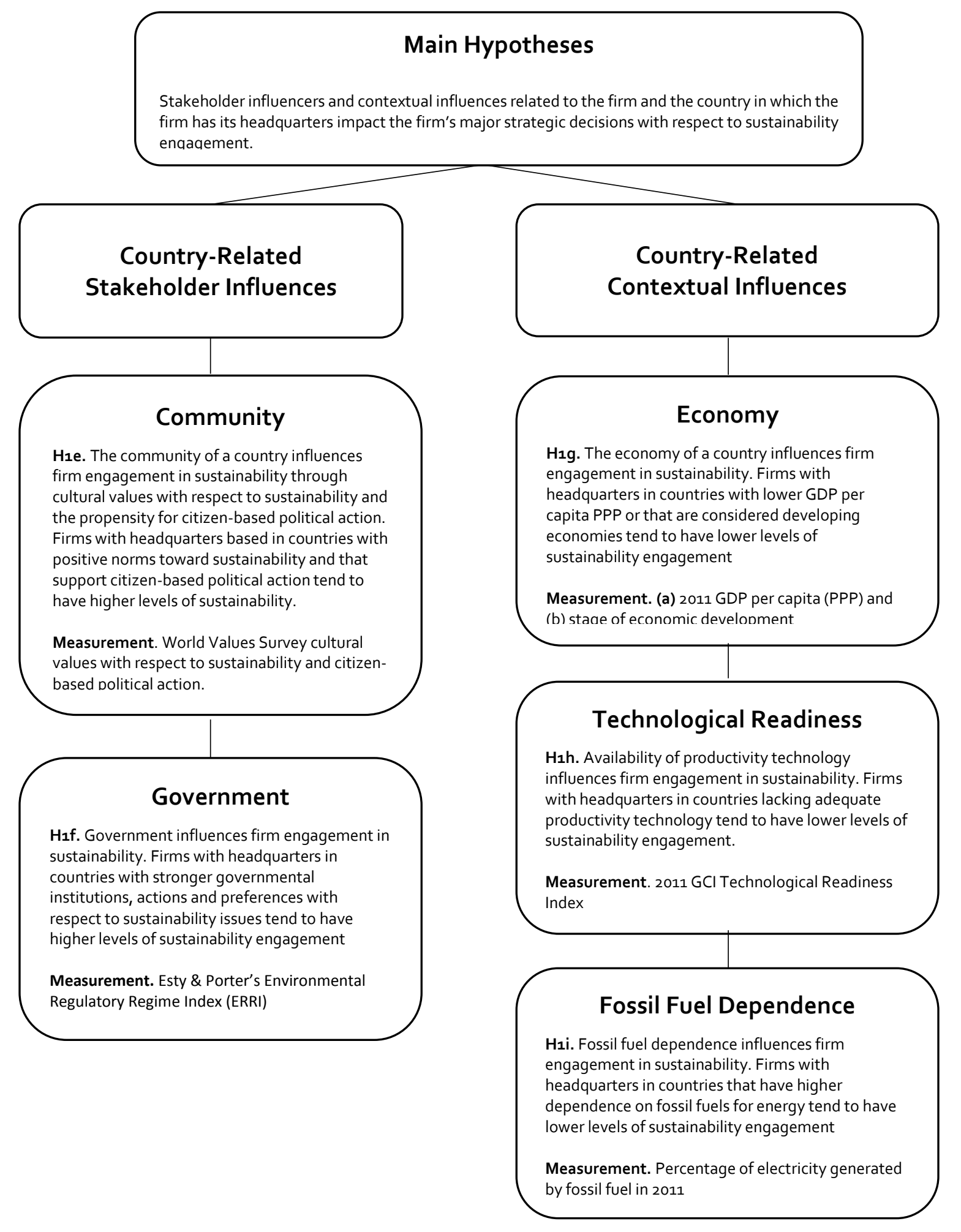

Figure 5. Country-Related Influence Factors: Hypotheses and Measurement Models 


\section{Community as Stakeholder Influence Factor}

Increasingly, there are pressures that businesses can and should have a significant impact on communities and the socioeconomic well-being of the countries in which they do business (Brammer et al., 2007; Campbell, 2007; Cumming, Bettridge, \& Toyne, 2005; Margolis \& Walsh, 2003). Companies are more likely to pursue broader social benefits beyond profit maximization goals and shareholder value when they feel pressures at the community level (Dimaggio \& Powell, 1991; Doh \& Guay, 2006; Marquis, Glynn, \& Davis, 2007; O’Higgins, 2010; Tolbert \& Zucker, 1996; Wilkes, 2005). Communities may be important influences on corporate social action “... because local understandings, norms, and rules can serve as touchstones for legitimizing corporate social action (Marquis et al., 2007, p.927).” Doh \& Guay (2006) found that variations in social, political, economic or geographic attributes affected expectations about corporate responsibilities to society and the legitimacy of stakeholders.

According to institution theory, organizations seek legitimacy within their environments and are influenced by the institutional settings in which they operate. Communities may be considered informal institutions that are based on behavioral norms, culture, beliefs, and/or geographical differences (Doh \& Guay, 2006; Keim, 2003; North, 1991, 1994). Values underlying social and cultural norms provide expectations of behavior socially, politically, and economically. Businesses are not exempt from these behavioral norms. Scholars have argued that organizations must be concerned about establishing social legitimacy because they are embedded in societal environments that form standards of behaviors (Logsdon \& Yuthas, 1997; Wood, 1991) 


\section{Hypothesis}

H1e. The community of a country as a stakeholder influences firm engagement in sustainability through cultural values supporting sustainability and the propensity for citizen-based political action. Firms with headquarters based in countries with positive norms toward sustainability and that support citizen-based political action tend to have higher levels of sustainability engagement.

\section{Measurement}

Community as stakeholder influencer was represented by country cultural values with respect to sustainability and the propensity for citizen-based political action. Cultural values were measured using country-level responses to several questions from the World Values Survey. ${ }^{18}$ Twenty-three questions from the survey were initially evaluated as potential measures and, of these, four questions were chosen as most representative of community as stakeholder influencer on firm engagement in sustainability (Appendix F).

A composite score was developed as representative of the population's cultural values on sustainability combined with the cultural values for the propensity for citizenbased political action in each applicable country. The score was calculated by averaging

\footnotetext{
${ }^{18}$ Source: World Values Survey 1981-2008 Official Aggregate v. 20090901, 2009. World Values Survey Association (www.worldvaluessurvey.org). Aggregate File Producer: ASEP/JDS, Madrid. Description from the website: "The European Value Survey (EVS) and the World Value Survey (WVS) are two largescale, cross-national and longitudinal survey research programs. They include a large number of questions which have been replicated since the early eighties. About 102 countries/regions with altogether 423,084 respondents participated in the six waves conducted up to now: 1981-1984, 1989-1993, 1994-1999, 19992004, 2005-2006, and 2008-2010."
} 
the percentage of the population in each country responding have done or might do for World Values Survey questions 96, 97, and 98, and then averaging that result with the percentage of the population in each country choosing the following response for World Values Survey question 104: Protecting the environment should be given priority, even if it causes slower economic growth and some loss of jobs (Table 6).

A limitation of using the World Values Survey was that data was not available for Singapore and the Philippines for calculating the measures. The impact was relatively minor for significance testing, however, because the smallest sample size for the entire project due to missing data for these measures was 368 cases. Table 7 shows the descriptive statistics for the firms in the sample set for community as measured by the cultural values composite score. 


\section{Table 6}

\section{Community Stakeholder Composite Score Calculation Method}

\begin{tabular}{|c|c|}
\hline $\begin{array}{l}\text { World Values Survey } \\
\text { Questions }\end{array}$ & Composite Score Calculation \\
\hline Q.Vg6 19 & The composite score for each \\
\hline Political action: & country (representing "community") \\
\hline Signing a petition & $\begin{array}{l}\text { was calculated by averaging the } \\
\text { percentage of the population in each }\end{array}$ \\
\hline Q.V97 & country responding have done or \\
\hline Political action: & might do for questions $\mathrm{Q} . \mathrm{V}_{96}$, \\
\hline Joining in boycotts & $\begin{array}{l}\text { Q.V } 97 \text {, and } Q . V_{98} \text {, then averaging } \\
\text { that result with the percentage }\end{array}$ \\
\hline Q.V98 & choosing the response protecting the \\
\hline Political action: & environment should be given priority, \\
\hline $\begin{array}{l}\text { Attending lawful/peaceful } \\
\text { demonstrations }\end{array}$ & $\begin{array}{l}\text { even if it causes slower economic } \\
\text { growth and some loss of jobs for } \\
\text { question } \mathrm{Q} . \mathrm{V}_{104} \text {. }\end{array}$ \\
\hline Q.V104 & \\
\hline $\begin{array}{l}\text { Protecting environment vs. } \\
\text { economic growth }\end{array}$ & (Cronbach's Alpha = .847) \\
\hline
\end{tabular}

Note: Country data for World Survey Values questions retrieved from World Valves Survey, http://www.wvsevsdb.com)

\footnotetext{
${ }^{19}$ Note: Shorthand versions of the questions are given in the results section of the World Values Survey and are those used in Table 6. Following are long versions of each question. Question V96: "Now I'd like you to look at this card. I'm going to read out some different forms of political action that people can take, and I'd like you to tell me, for each one, whether you have actually done any of these things, whether you might do it or would never, under any circumstances, do it. Signing a petition." Question V97: "Now I'd like you to look at this card. I'm going to read out some different forms of political action that people can take, and I'd like you to tell me, for each one, whether you have actually done any of these things, whether you might do it or would never, under any circumstances, do it. Joining in boycotts." Question V98 reads in its entirety: "Now I'd like you to look at this card. I'm going to read out some different forms of political action that people can take, and I'd like you to tell me, for each one, whether you have actually done any of these things, whether you might do it or would never, under any circumstances, do it. Attending lawful/peaceful demonstrations." Question V104: "Here are two statements people sometimes make when discussing the environment and economic growth. Which of them comes closer to your own point of view? A. Protecting the environment should be given priority, even if it causes slower economic growth and some loss of jobs; B. Economic growth and creating jobs should be the top priority, even if the environment suffers to some extent. Possible answers: 1) protecting environment; 2) economy growth and creating jobs; 3) other answer; -1) don't know; -2) no answer; -3) not applicable; -4) not asked in survey; -5) missing; unknown". Source: The World Values Survey, http://www.wvsevsdb.com/wvs/WVSIntegratedEVSWVS.jsp?Idioma=I
} 
Table 7

Descriptive Statistics of Community Stakeholder for Firms in Sample Set as Measured by Cultural Values for Sustainability and Propensity for CitizenBased Political Action (Composite Score, \% of country population)

\begin{tabular}{lccccc}
\hline & Mean & $\begin{array}{l}\text { Standard } \\
\text { Deviation }\end{array}$ & Minimum & Maximum & N \\
\hline $\begin{array}{l}\text { Community } \\
\text { Stakeholder }\end{array}$ & 56.00 & 12.70 & 31.70 & 74.10 & 368 \\
Influence: & & & & \\
Cultural Values for & & & & \\
Sustainability and & & & & \\
Propensity for & & & \\
Citizen-Based & & & \\
Political Action & & & \\
\hline
\end{tabular}

Note: Country data for World Survey Values questions retrieved from World Values Survey, http://www.wvsevsdb.com) 


\section{Government as Stakeholder Influence Factor}

Sustainability actions undertaken by businesses are both regulatory and voluntary in nature. Environmental sustainability performance is typically regulated at the domestic government level (Esty \& Porter, 2005). Legal requirements, such as minimum pollution control standards or minimum labor conditions, are established in domestic regulatory regimes that are complex, vary by jurisdiction, or may exist only marginally (Esty \& Porter, 2005). On the other hand, sustainability commitments for shared global issues, such as climate change, are more dependent on country-level voluntary compliance and national interests often may take priority (Axelrod, Vandeveer, et al., 2011). The distinctions are critical because of the variability in actions that business organizations may make in response to the influence of governmental institutions, actions and preferences with respect to sustainability issues.

Institutional theory has a core argument that organizations seek legitimacy within their environments and are influenced by the institutional settings in which they operate (Dimaggio \& Powell, 1991; Doh \& Guay, 2006; Tolbert \& Zucker, 1996). Formal institutions, such as governments, are those based on formal agreements such as constitutions, laws and policies; (Doh \& Guay, 2006; Keim, 2003; North, 1991, 1994). Doh \& Guay (2006) found, that when compared to the United States, Europe's institutional settings had relatively more advanced awareness and support for CSR that influenced not only public policy issues but also corporate strategies, concluding that differences in institutional environments arising from social, political, economic, or 
geographical variations affect expectations about corporate responsibilities to society and the legitimacy of stakeholders.

\section{Hypothesis}

H1f. Government as a stakeholder influences firm engagement in sustainability. Firms with headquarters in countries with stronger governmental institutions, actions, and preferences with respect to sustainability issues tend to have higher levels of sustainability engagement.

\section{Measurement}

Government stakeholder influence was measured using data from the Environmental Regulatory Regime Index (ERRI). The ERRI score for each country was developed by Esty \& Porter (2005) based on environmental regulatory and institutional regime criteria for the country. Criteria included environmental regulatory standards; implementation and enforcement mechanisms and associated institutions for pollution control and natural resource management; the stringency of pollution standards; the sophistication of the regulatory structure; the availability of relevant policy-making information; the availability of subsidization of natural resources; the strictness of regulatory enforcement; and the capacity of a country's environmental institutions (Esty \& Porter, 2005). Appendix E is an illustrative model of the ERRI methodology (Esty \& Porter, 2005, Figure 1, p. 395). 
Table 8 shows ERRI data for the countries in the sample set. A higher ERRI indicates a stronger governmental regime. Table 9 shows descriptive statistics for government for the firms in the sample set as measured by ERRI. 


\section{Table 8}

Government Stakeholder Strength Based on ERRI for Countries in Sample Set

\begin{tabular}{|c|c|}
\hline Country & ERRI \\
\hline Australia & 1.083 \\
\hline Brazil & -0.077 \\
\hline Canada & 1.297 \\
\hline Chile & 0.177 \\
\hline China & -0.348 \\
\hline France & 1.464 \\
\hline Germany & 1.522 \\
\hline India & -0.759 \\
\hline Indonesia & -0.758 \\
\hline Italy & 0.498 \\
\hline Japan & 1.057 \\
\hline Korea, Republic of & -0.121 \\
\hline Malaysia & -0.127 \\
\hline Mexico & -0.602 \\
\hline Netherlands & 1.747 \\
\hline Philippines & -1.014 \\
\hline Russia & -0.895 \\
\hline Singapore & 1.771 \\
\hline South Africa & -0.029 \\
\hline Spain & 0.437 \\
\hline Sweden & 1.772 \\
\hline Switzerland & 1.631 \\
\hline Thailand & -0.389 \\
\hline United Kingdom & 1.185 \\
\hline United States & 1.184 \\
\hline
\end{tabular}

Note: Country ERRI data retrieved from Esty \& Porter (2005), Table 8, p.418 
Table 9

Descriptive Statistics of Government Stakeholder for Firms in Sample Set as Measured by ERRI

\begin{tabular}{lccccc}
\hline & Mean & $\begin{array}{l}\text { Standard } \\
\text { Deviation }\end{array}$ & Minimum & Maximum & N \\
\hline $\begin{array}{l}\text { Government } \\
\text { Stakeholder }\end{array}$ & 0.47 & 0.94 & -1.01 & 1.77 & 400 \\
$\begin{array}{l}\text { Influence: } \\
\text { Country ERRI }\end{array}$ & & & & & \\
& & & & & \\
\hline
\end{tabular}

Note: Country ERRI data retrieved from Esty \& Porter (2005), Table 8, p.418 


\section{Country Economy as Contextual Influence Factor}

Baughn et al. (2007) found that country economic factors, such as gross domestic product per capita and country distribution of income were significantly related to corporate social responsibility. Country economy is an external attribute that may impact the strategic decisions of a firm.

\section{Hypothesis}

H1g. The economy of a country influences firm engagement in sustainability. Firms with headquarters in countries that have lower GDP per capita PPP or that are considered developing economies tend to have lower levels of sustainability engagement.

\section{Measurement}

Country economy as an influence factor on firm engagement in sustainability was investigated using two measures: (a) the country’s 2011 gross domestic product per capita based on purchasing-power-parity (GDP) and (b) the country's stage of economic development.

Data for GDP were obtained from the World Bank and are shown in Table 10 for the countries in the sample set of companies. ${ }^{20}$ GDP was used as a measure to determine whether the economic purchasing power per capita of the country was generally associated with firm engagement in sustainability. Descriptive statistics of country economy as measured by GDP for the firms in the sample set are shown in Table 11.

\footnotetext{
${ }^{20}$ Source: World Bank, International Comparison Program database, http://data.worldbank.org/indicator/NY.GDP.PCAP.PP.CD
} 


\section{Table 10}

\section{GDP per capita PPP for Countries in Sample Set} (International Dollars)

\begin{tabular}{lc}
\hline Country & $\begin{array}{c}\text { 2011 GDP per capita PPP } \\
\text { (international dollars) }\end{array}$ \\
\hline Australia & 42,119 \\
Brazil & 11,634 \\
Canada & 41,392 \\
Chile & 20,984 \\
China & 8,408 \\
France & 35,366 \\
Germany & 39,456 \\
India & 3,714 \\
Indonesia & 4,615 \\
Italy & 32,648 \\
Japan & 33,838 \\
Korea, Republic of & 29,786 \\
Malaysia & 16,122 \\
Mexico & 16,013 \\
Netherlands & 42,779 \\
Philippines & 4,104 \\
Russia & 22,408 \\
Singapore & 61,070 \\
South Africa & 11,028 \\
Spain & 30,087 \\
Sweden & 41,453 \\
Switzerland & 51,227 \\
Thailand & 9,037 \\
United Kingdom & 35,586 \\
United States & 48,113 \\
\hline & \\
\hline &
\end{tabular}

Note: Country GDP per capita PPP data retrieved from the World Bank, International Comparison Program database, http://data.worldbank.org/indicator/NY.GDP.PCAP.PP.CD

\footnotetext{
${ }^{21}$ Note: The derivation of GDP per capita based on purchasing-power-parity is described by World Bank as follows: "GDP per capita based on purchasing power parity is gross domestic product converted to international dollars using purchasing power parity rates. An international dollar has the same purchasing power over GDP as the U.S. dollar has in the United States. GDP at purchaser's prices is the sum of gross value added by all resident producers in the economy plus any product taxes and minus any subsidies not included in the value of the products. It is calculated without making deductions for depreciation of fabricated assets or for depletion and degradation of natural resources. Data are in current international dollars." Source: World Bank, International Comparison Program database, http://data.worldbank.org/indicator/NY.GDP.PCAP.PP.CD
} 
Table 11

Descriptive Statistics of Country Economy for Firms in Sample Set as Measured by 2011 GDP per capita PPP

(International Dollars, thousands)

\begin{tabular}{lccccc}
\hline & Mean & $\begin{array}{l}\text { Standard } \\
\text { Deviation }\end{array}$ & Minimum & Maximum & N \\
\hline $\begin{array}{l}\text { Country economy: } \\
\text { 2011 GDP per } \\
\text { capita PPP }\end{array}$ & 26.86 & 15.77 & 3.67 & 59.60 & 400 \\
& & & & & \\
\hline
\end{tabular}

Source: Country GDP per capita PPP retrieved from the World Bank, International Comparison

Program database, http://data.worldbank.org/indicator/NY.GDP.PCAP.PP.CD 
The country's stage of economic development was used as a second measure to obtain more granular information about the relationship of economic development to firm engagement in sustainability. According to data retrieved from the World Bank, there are 143 developing countries ${ }^{22}$ (Appendix G), representing approximately 74\% of the 193 countries in the world. ${ }^{23}$ Several of the developing countries are also categorized as rapidly developing by the OECD, most recently consisting of Brazil, Russian Federation, India, Indonesia, China, and South Africa, or the BRIICS countries. ${ }^{24}$

Using the World Bank and OECD categories, each country in the sample set was categorized into one of the following: developed economy, rapidly developing economy or other developing economy, as shown in Table 12. Descriptive statistics for stage of economic development for the firms in the sample set are shown in Table 13. Note that, although developing countries make up approximately $74 \%$ of the world's countries, only $44 \%$ of the firms in the sample set are headquartered in developing countries.

\footnotetext{
${ }^{22}$ Source: : http://www.isi-web.org/component/content/article/5-root/root/81-developing

${ }^{23}$ Note: Estimates of the total number of countries in the world vary from 189 to 196, depending on interpretation of political jurisdictions and other evaluations. A commonly used estimate is 193 countries. Source: http://www.worldatlas.com/nations.htm

${ }^{24}$ Note: The following countries were identified as rapidly developing economies by OECD: Brazil, Russian Federation, India, Indonesia, China, and South Africa (BRIICS). Source: http://www.oecd.org/tad/tradedev/globalisationandemergingeconomies.htm
} 
Table 12

Stage of Economic Development for Countries in Sample Set

\begin{tabular}{|c|c|c|}
\hline $\begin{array}{l}\text { Developed } \\
\text { Economies }\end{array}$ & $\begin{array}{l}\text { Rapidly Developing } \\
\text { Economies } \\
\text { (BRIICS countries) }\end{array}$ & $\begin{array}{l}\text { Other Developing } \\
\text { Economies }\end{array}$ \\
\hline $\begin{array}{l}\text { Australia } \\
\text { Canada } \\
\text { France } \\
\text { Germany } \\
\text { Italy } \\
\text { Japan } \\
\text { Korea, Republic of } \\
\text { Netherlands } \\
\text { Singapore } \\
\text { Spain } \\
\text { Sweden } \\
\text { Switzerland } \\
\text { United Kingdom } \\
\text { United States }\end{array}$ & $\begin{array}{l}\text { Brazil } \\
\text { China } \\
\text { India } \\
\text { Indonesia } \\
\text { Russian Federation } \\
\text { South Africa }\end{array}$ & $\begin{array}{l}\text { Chile } \\
\text { Malaysia } \\
\text { Mexico } \\
\text { Philippines } \\
\text { Thailand }\end{array}$ \\
\hline
\end{tabular}

Note: Country stage of economic development data was retrieved from ISI and World Bank, http://www.isi-web.org/component/content/article/5-root/root/81-developing, and OECD, http://www.oecd.org/tad/tradedev/globalisationandemergingeconomies.htm 
Table 13

Stage of Economic Development Distribution of Firms in Sample Set

Stage of Economic Development

$\mathbf{N}$

Developed Economies

224

Rapidly Developing Economies (BRIICS)

96

Other Developing Economies

80

Note: Country stage of economic development data was retrieved from ISI and World Bank, http://www.isi-web.org/component/content/article/5-root/root/81-developing, and OECD, http://www.oecd.org/tad/tradedev/globalisationandemergingeconomies.htm 


\section{Technological Readiness as Contextual Influence Factor}

Technological readiness is a term used to describe "...the agility with which an economy adopts existing technologies to enhance the productivity of its industries, with specific emphasis on its capacity to fully leverage information and communication technologies in daily activities and production processes for increased efficiency and enabling innovation for competitiveness (Schwab, 2012, p. 6)."25

\section{Hypothesis}

H1h. Availability of productivity technology in the country influences firm engagement in sustainability. Firms with headquarters in countries lacking adequate productivity technology tend to have lower levels of sustainability engagement.

\section{Measurement}

Country technological readiness was measured using the 2011 GCI Technological Readiness Score for each country obtained from The Global Competitiveness Report (Schwab, 2012). The GCI Technological Readiness Score for a country was computed from seven components: availability of latest technologies; firm-level technology absorption, foreign direct investment and technology transfer; \% individuals using internet; broadband internet subscriptions/100 population; international internet bandwidth, kb/s per user; and mobile broadband subscriptions/100 population (Schwab,

\footnotetext{
${ }^{25}$ Note: The World Economic Forum produces The Global Competitiveness Report annually that provides detailed assessments of the productive potential of nations worldwide. Technological readiness is one of the attributes used as a measure for the productivity potential of a country. See Appendix G for more information on The Global Competitiveness Report. Available from http://www.weforum.org/reports/global-competitiveness-report-2011-2012.
} 
2012, pp. 6, 488-494, 521-522). Appendix G provides additional information on The Global Competitiveness Report and the GCI technological readiness score. The GCI Technological Readiness Score for each country in the sample set is shown in Table 14. Descriptive statistics for technological readiness for the firms in the sample set are shown in Table 15. 
Table 14

2011 GCI Technological Readiness Scores for Countries in Sample Set

\begin{tabular}{|c|c|}
\hline Country & $\begin{array}{c}2011 \text { GCI Technological } \\
\text { Readiness Score }\end{array}$ \\
\hline Australia & $5 \cdot 61$ \\
\hline Brazil & 4.43 \\
\hline Canada & 5.60 \\
\hline Chile & $4 \cdot 48$ \\
\hline China & $3 \cdot 50$ \\
\hline France & 5.72 \\
\hline Germany & 5.71 \\
\hline India & 3.36 \\
\hline Indonesia & 3.56 \\
\hline Italy & 4.71 \\
\hline Japan & 5.70 \\
\hline Korea, Republic of & $5 \cdot 70$ \\
\hline Malaysia & $4 \cdot 31$ \\
\hline Mexico & 3.80 \\
\hline Netherlands & $5 \cdot 98$ \\
\hline Philippines & 3.63 \\
\hline Russia & 4.13 \\
\hline Singapore & 6.10 \\
\hline South Africa & 4.01 \\
\hline Spain & 5.29 \\
\hline Sweden & 6.29 \\
\hline Switzerland & 6.02 \\
\hline Thailand & 3.56 \\
\hline United Kingdom & 6.00 \\
\hline United States & 5.84 \\
\hline
\end{tabular}

Note: Country GCI technological readiness score data retrieved from Schwab, K., \& Sala-iMartin, X. (2012), The Global Competitiveness Report, World Economic Forum, Geneva, http://www.weforum.org/issues/global-competitiveness 
Table 15

Descriptive Statistics of Country Technological Readiness for Firms in Sample Set as Measured by 2011 GCI Technological Readiness Score

\begin{tabular}{lccccc}
\hline & Mean & $\begin{array}{c}\text { Standard } \\
\text { Deviation }\end{array}$ & Minimum & Maximum & N \\
\hline $\begin{array}{l}\text { Country } \\
\text { technological }\end{array}$ & 4.92 & 0.99 & 3.36 & 6.29 & 400 \\
readiness: & & & & & \\
$2011 \mathrm{GCl}$ & & & & \\
Technological & & & & \\
Readiness Score & & & & \\
& & & & \\
\hline
\end{tabular}

Note: Country GCI technological readiness score data retrieved from Schwab, K., \& Sala-iMartin, X. (2012), The Global Competitiveness Report, World Economic Forum, Geneva, http://www.weforum.org/issues/global-competitiveness 


\section{Fossil Fuel Dependence as Contextual Influence Factor}

A country with a substantial dependence on fossil fuels for energy needs or other industrial purposes may influence a firm's strategy choices, including decisions regarding sustainability actions. Fossil fuel generation has been found to be associated with greenhouse gas emissions (GHGs) contributing to environmental problems of global warming and climate change (Dixon, 2007; Feltrin \& Freundlich, 2008; Gilau, Van Buskirk, \& Small, 2007; Kaygusuz, 2007; Tsoutos, Frantzeskaki, \& Gekas, 2005; Wustenhagen, Wolsink, \& Burer, 2007). Sustainability efforts often include pollution and emissions controls that may be more difficult to accomplish in countries with substantial dependency on fossil fuels.

\section{Hypothesis}

H1i. Fossil fuel dependence influences firm engagement in sustainability. Firms with headquarters in countries that have higher dependence on fossil fuels for energy tend to have lower levels of sustainability engagement.

\section{Measurement}

Country dependence on fossil fuels was measured using data from 2011 Mergent Online Country Profile reports. ${ }^{26}$ The energy statistics section in the Mergent country profile reports profiles the percentages of electricity produced by various sources. To obtain the measure of dependence on fossil fuel, the percentages of electricity produced

\footnotetext{
${ }^{26}$ Note: Country profiles are published by Mergent, Inc., Fort Mill, South Carolina. Mergent, Inc. is a leading provider of global business and financial information on publicly traded companies. Sources: http://www.mergent.com/; George Fox University library access to Mergent Online database.
} 
by natural gas, coal or oil were added for each country. This measure is limited in that it is based on the use of fossil fuels for electricity generation only and does not take into account other potential uses of fossil fuels in the country. The measure is useful, however, as an approximation of fossil fuel dependence. The percentage of electricity produced by fossil fuels for each country in the sample set is shown in Table 16. Descriptive statistics of country fossil fuel dependence for the firms in the sample set are shown in Table 17. 
Table 16

Amount of Electricity Produced by Fossil Fuels in 2011 for Countries in Sample Set

\begin{tabular}{lc}
\hline Country & $\begin{array}{c}\text { 2011 Percentage of Electricity } \\
\text { Produced by Fossil Fuels }\end{array}$ \\
\hline Australia & 57.0 \\
Brazil & 8.3 \\
Canada & 24.5 \\
Chile & 51.0 \\
China & 80.6 \\
France & 11.4 \\
Germany & 24.5 \\
India & 83.9 \\
Indonesia & 86.8 \\
Italy & 84.0 \\
Japan & 66.3 \\
Korea, Republic of & 62.4 \\
Malaysia & 94.0 \\
Mexico & 81.8 \\
Netherlands & 78.9 \\
Philippines & 100.0 \\
Russia & 64.7 \\
Singapore & 100.0 \\
South Africa & 93.3 \\
Spain & 61.9 \\
Sweden & 9.4 \\
Switzerland & 37.1 \\
Thailand & 93.1 \\
United Kingdom & 73.8 \\
United States & 67.9 \\
& \\
\hline
\end{tabular}

Note: Country data for percentage of electricity produced by fossil fuels retrieved from Mergent country reports, Mergent Online, http://mergent.com 
Table 17

Descriptive Statistics of Country Fossil Fuel Dependence for Firms in Sample Set as Measured by Amount of Electricity Produced by Fossil Fuels in 2011 (\%)

\begin{tabular}{lccccc}
\hline & Mean & $\begin{array}{c}\text { Standard } \\
\text { Deviation }\end{array}$ & Minimum & Maximum & N \\
\hline $\begin{array}{l}\text { Country Fossil Fuel } \\
\text { Dependence: }\end{array}$ & 63.86 & 28.58 & 8.30 & 100.00 & 400 \\
$\begin{array}{l}2011 \text { Electricity } \\
\text { Produced by Fossil } \\
\text { Fuels (\%) }\end{array}$ & & & & & \\
\end{tabular}

Note: Country data for percentage of electricity produced by fossil fuels retrieved from Mergent country reports, Mergent Online, http://mergent.com 


\section{Chapter 4}

\section{Analysis and Results}

Influence factors on firm engagement in sustainability were investigated by analyzing each individual variable using regression or ANOVA, as appropriate to the data. The intent of the individual analyses was to determine whether each influence factor had significant association with firm engagement in sustainability as an individual factor. Pathways of influence for each factor likely vary. Initially determining if a factor is a significant influencer provides the groundwork for future study of specific pathways of influence.

Following the individual analyses for each influence factor, a comprehensive study testing the main hypothesis was conducted using multiple regression. The comprehensive study investigated the combined effect of the stakeholder influence factors and several of the contextual influence factors as related to firm engagement in sustainability.

Figure 6 is a summary of the analysis model and the results obtained. Briefly, the results showed that all of the stakeholder influence factors studied were individually significantly associated with firm engagement in sustainability. In addition, except for firm financial performance, all of the contextual influence factors were individually significantly associated with firm engagement in sustainability.

In the comprehensive study, the stakeholder influence factors - executive management, community and government - remained significantly associated with firm 
engagement in sustainability. Two contextual influence factors - firm size and technological readiness - were also significantly related to firm engagement in sustainability. Combined, the influence factors in the comprehensive study showed a large correlation with firm engagement in sustainability $\left(\mathrm{R}^{2}=.255, \mathrm{~F}(6,361)=20.568, \mathrm{p}\right.$ $<.000$ ), indicating that approximately $26 \%$ of the variation in firm sustainability engagement could be explained by the combined influence of the factors tested.

This section is organized as follows. Analyses and results of the individual firmrelated influence factors are presented first, followed by the analyses and results of the individual country-related factors. The section concludes with the analyses and results of the comprehensive study. 


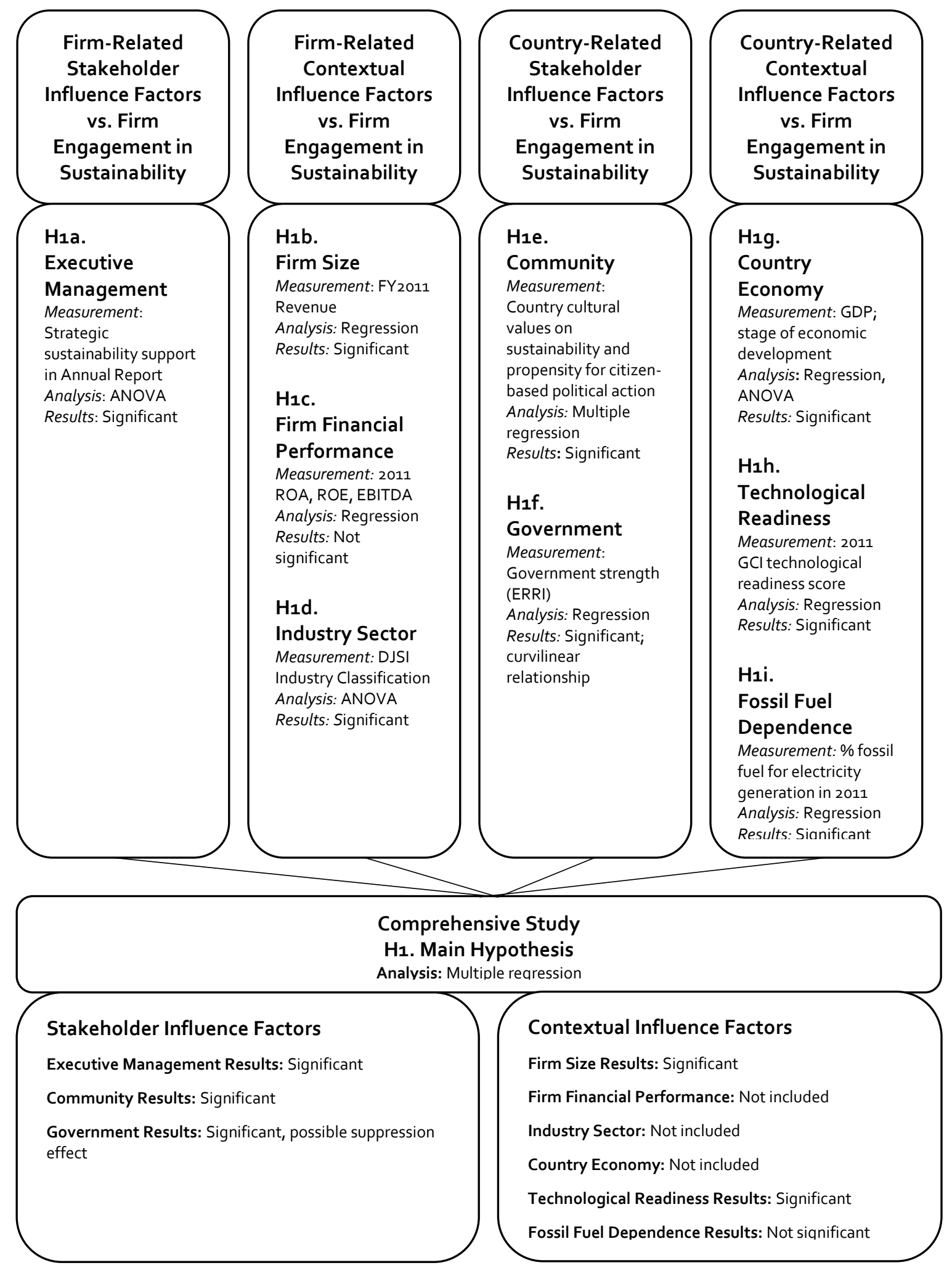

Figure 6. Analysis Model and Summary of Results 


\section{Analysis of Individual Firm-Related Influence Factors}

\section{Executive Management}

Executive Management as a stakeholder was hypothesized to influence firm engagement in sustainability. Firms with executive management that showed explicit strategic support for sustainability in firm annual reports were hypothesized to have higher levels of sustainability engagement (H1a).

A one-way ANOVA was used to test for differences among the three levels of top management strategic support for sustainability. ${ }^{27}$ Firm sustainability engagement differed significantly across the three levels of executive management strategic support for sustainability, $\mathrm{F}(2,397)=11.289, \mathrm{p}<.000)$, supporting hypothesis H1a.

Tukey and Games-Howell post-hoc comparisons of the three groups indicated that firms with executive management that placed the highest value on sustainability as a strategic component of the firm as evidenced by extensive discussion of sustainability in their annual reports had significantly higher sustainability engagement $(\mathrm{M}=34.02)$ than firms with executive management that had no mention of sustainability in their annual reports $(\mathrm{M}=23.80), \mathrm{p}<.000$. Comparisons between firms with top management that had some mention of sustainability in their annual reports and the other two groups were not statistically significant at $p<.05$. Table 18 is a summary of the ANOVA statistics of executive management stakeholder influence on firm engagement in sustainability.

\footnotetext{
${ }^{27}$ See Table 2 for descriptions.
} 
Table 18

ANOVA Statistics of Executive Management Stakeholder Influence on Firm Engagement in Sustainability

Executive $\quad$ Firm

Management

Sustainability

Strategic Support Engagement Standard

of Sustainability (Mean ESG Score)

Extensive discussion

$34.02 *$

18.58

246

of sustainability in

Annual Report

Some mention of

30.25

15.24

54

sustainability in

Annual Report

No mention of

$23.80 *$

18.60

100

sustainability in

Annual Report

\section{Sample Set}

30.95

18.64

400

*Pair comparison significant, $p<.000$ 


\section{Firm Size}

Firm size as a contextual factor was hypothesized to influence firm engagement in sustainability. Larger firms were hypothesized to have higher levels of sustainability engagement $(\mathrm{H} 1 \mathrm{~b})$.

A regression analysis indicated that firm size, as measured by 2011 revenue, was significantly associated with firm engagement in sustainability $(\mathrm{B}=.225, \mathrm{SE}=.031, \beta=$ $.338, \mathrm{p}<.000)$, supporting hypothesis H1b. Larger companies tended to have higher levels of sustainability engagement.

Overall, there was a moderate positive correlation between firm size and firm engagement in sustainability $\left(\mathrm{R}^{2}=.115, \mathrm{~F}(1,398)=51.466, \mathrm{p}<.000\right)$, indicating that approximately $12 \%$ of the variation of a firm's engagement in sustainability could be explained firm size as stakeholder influencer, when not controlling for other factors.

\section{Firm Financial Performance}

Firm financial performance as a contextual factor was hypothesized to be associated with firm engagement in sustainability (H1c). Multiple regression analysis indicated that firm financial performance, as measured by return on assets (ROA), return on equity (ROE) and earnings before interest, taxes, depreciation and amortization (EBITDA) was not significantly related to firm engagement in sustainability (ns). Hypothesis H1c was not supported. 


\section{Industry Sector}

Industry sector as a contextual factor was hypothesized to influence firm engagement in sustainability, with firms in certain industries tending to have higher levels of sustainability engagement when compared to firms in other industries (H1d).

A one-way ANOVA indicated that firm sustainability engagement differed significantly across the nineteen industry sectors, $F(18,381)=2.112, \mathrm{p}<.005)$, supporting hypothesis H1d.

Tukey and Games-Howell post-hoc comparisons of the nineteen groups indicated significant differences between several industry sectors. Firm engagement in sustainability was significantly higher for the Oil \& Gas industry sector $(M=40.27)$ when compared to firm engagement in sustainability in the Real Estate industry segment $(M=16.80, p<.001)$ and firm engagement in sustainability in the Financial Services industry segment $(\mathrm{M}=19.77, \mathrm{p}<.05)$. Firm engagement in sustainability was approximately $140 \%$ higher in the Oil \& Gas industry segment compared to the Real Estate segment and approximately 104\% higher compared to the Financial Services industry segment. Firm engagement in sustainability also was significantly higher for the Industrial Goods industry sector $(\mathrm{M}=34.98)$ when compared to the Real Estate sector $(16.80, \mathrm{p}<.005)$, differing by approximately $108 \%$. Comparisons between firms in other industry segments were not statistically significant at $\mathrm{p}<.05$. Table 19 is a summary of the ANOVA statistics of industry segment influence on firm engagement in sustainability. 
A two-way factorial ANOVA between industry sector and executive management support of sustainability indicated that there were no interaction effects on firm engagement of sustainability with these two influence factors (ns). 
Table 19

ANOVA Statistics of Industry Segment Influence on Firm Engagement in Sustainability

\begin{tabular}{|c|c|c|c|}
\hline Industry Sector & $\begin{array}{l}\text { Firm } \\
\text { Sustainability } \\
\text { Engagement } \\
\text { (Mean ESG Score) }\end{array}$ & $\begin{array}{l}\text { Standard } \\
\text { Deviation }\end{array}$ & $\mathbf{N}$ \\
\hline Automobile \& Parts & 37.02 & 20.03 & 17 \\
\hline Banks & 29.20 & 19.67 & 35 \\
\hline Chemicals & 34.01 & 18.55 & 16 \\
\hline Construction \& Materials & 33.29 & 17.20 & 18 \\
\hline Financial Services ${ }^{\wedge}$ & 19.77 & 14.41 & 17 \\
\hline Food \& Beverage & 28.41 & $17 \cdot 39$ & 33 \\
\hline Healthcare & 32.74 & 16.92 & 18 \\
\hline Personal/Household Goods & 33.62 & 21.35 & 17 \\
\hline Industrial Goods/Services" & 34.98 & 19.65 & 40 \\
\hline Insurance & 37.68 & 18.71 & 10 \\
\hline Basic Materials & 28.98 & 17.02 & 36 \\
\hline Media & 23.87 & 16.16 & 13 \\
\hline Oil \& Gas ${ }^{\star \wedge}$ & 40.27 & 17.18 & 28 \\
\hline Real Estate*\# & 16.80 & 12.73 & 17 \\
\hline Retail & 23.65 & 18.95 & 14 \\
\hline Technology & 34.91 & 23.79 & 12 \\
\hline Telecommunications & 31.05 & 16.27 & 16 \\
\hline Travel \& Leisure & 27.98 & 11.06 & 17 \\
\hline Utilities & 34.13 & 22.13 & 26 \\
\hline Sample Set & 30.95 & 18.64 & 400 \\
\hline
\end{tabular}

*Pair comparison significant, $\mathrm{p}<.001$

${ }^{\wedge}$ Pair comparison significant, $\mathrm{p}<.05$

\#Pair comparison significant, $\mathrm{p}<.05$ 


\section{Analysis of Individual Country-Related Influence Factors}

\section{Country Variation in Firm Engagement in Sustainability}

An initial analysis was conducted to determine whether there was variation in

firm engagement in sustainability by country. A one-way ANOVA showed that there were significant differences in firm engagement in sustainability among the twenty-five countries in the sample set $(\mathrm{F}(24,375)=5.809, \mathrm{p}<.000)$.

On average, firms that tended to have the highest engagement in sustainability were located in European countries with developed economies (France, $\mathrm{M}=49.03$; Italy, $M=41.87$; Spain, $M=49.19$; United Kingdom, $M=40.15)$. Firms that tended to have the lowest engagement in sustainability on average were located in South America and Asia with developing economies (Chile, $\mathrm{M}=19.25$; Indonesia, $\mathrm{M}=18.05$; Malaysia, $\mathrm{M}$ =15.84; Philippines, $M=18.46$ ). Table 20 is a summary of the ANOVA statistics of country variation in firm engagement in sustainability. 
Table 20

ANOVA Statistics of Country Variation in Firm Engagement in Sustainability

\begin{tabular}{|c|c|c|c|}
\hline Country & $\begin{array}{l}\text { Firm } \\
\text { Sustainability } \\
\text { Engagement } \\
\text { (Mean ESG Score) }\end{array}$ & $\begin{array}{l}\text { Standard } \\
\text { Deviation }\end{array}$ & $\mathbf{N}$ \\
\hline Australia & 19.79 & 8.18 & 16 \\
\hline Brazil & 37.19 & 25.97 & 16 \\
\hline Canada & 27.16 & 13.29 & 16 \\
\hline Chile & 19.25 & 18.44 & 16 \\
\hline China & 24.23 & 9.80 & 16 \\
\hline France & 49.03 & 11.58 & 16 \\
\hline Germany & 33.04 & 18.29 & 16 \\
\hline India & 27.25 & 14.29 & 16 \\
\hline Indonesia & 18.05 & 11.53 & 16 \\
\hline Italy & 41.87 & 22.22 & 16 \\
\hline Japan & 38.67 & 12.42 & 16 \\
\hline Malaysia & 15.84 & 6.10 & 16 \\
\hline Mexico & 23.79 & 20.63 & 16 \\
\hline Netherlands & 37.82 & 14.96 & 16 \\
\hline Philippines & 18.46 & 14.84 & 16 \\
\hline Russia & 31.81 & 12.34 & 16 \\
\hline Singapore & 20.31 & 10.99 & 16 \\
\hline South Africa & 39.68 & 11.16 & 16 \\
\hline South Korea & 39.27 & 23.54 & 16 \\
\hline Spain & 49.19 & 20.89 & 16 \\
\hline Sweden & 36.79 & 13.87 & 16 \\
\hline Switzerland & 30.83 & 20.37 & 16 \\
\hline Thailand & 20.92 & $15 \cdot 59$ & 16 \\
\hline United Kingdom & 40.15 & 17.02 & 16 \\
\hline United States & 33.20 & 22.20 & 16 \\
\hline Sample Set & 30.95 & 18.64 & 400 \\
\hline
\end{tabular}




\section{Community}

The community of a country as a stakeholder was hypothesized to influence firm engagement in sustainability through cultural values supporting sustainability and the propensity for citizen-based political action. Firms with headquarters based in countries with positive norms toward sustainability and that support citizen-based political action were hypothesized to have higher levels of sustainability engagement (H1e).

Regression analysis indicated that there was a significant relationship between firm engagement in sustainability and community as a stakeholder influencer as measured by cultural values regarding sustainability and propensity for citizen-based political action $(\mathrm{B}=0.297, \mathrm{SE}=0.076, \beta=0.201, \mathrm{p}<.000)$, supporting hypothesis H1e. The findings indicated that firms with headquarters located in a country with positive norms toward sustainability combined with a propensity for citizen-based political action tended to have higher sustainability engagement.

Overall, there was a positive correlation between community and firm engagement in sustainability $\left(\mathrm{R}^{2}=.041, \mathrm{~F}(1,366)=15.451, \mathrm{p}<.000\right)$, indicating that approximately $4 \%$ of the variation of a firm's engagement in sustainability could be explained by community as stakeholder influencer, when not controlling for other factors. 


\section{Government}

Government as a stakeholder was hypothesized to influence firm engagement in sustainability (H1f). Firms with headquarters in countries with stronger governmental institutions, actions, and preferences with respect to sustainability issues were hypothesized to have higher levels of sustainability engagement.

The scatter plot shown in Figure 7 suggested that a curvilinear relationship existed between government strength as measured by ERRI and firm engagement in sustainability, as measured by ESG $\left(y=31.98+7.67 \mathrm{x}-4.22 \mathrm{x}^{2}\right)$. Linear and quadratic effects were tested with a multiple regression analysis. Results indicated that there was a significant linear effect in the relationship between firm engagement in sustainability and government strength $\left(\mathrm{B}_{1}=7.67, \mathrm{SE}_{1}=1.618, \beta_{1}=0.385, \mathrm{p}<.000\right)$ and also a significant quadratic effect in the relationship $\left(\mathrm{B}_{2}=-4.219, \mathrm{SE}_{2}=1.426, \beta_{2}=-0.240, \mathrm{p}<.005\right)$.

The curvilinear results suggest that firm engagement in sustainability increases as the strength of government increases, but only to a certain point. The maximum of the curve occurs when ERRI is equal to $0.91(\mathrm{x}=0.91, \mathrm{y}=38.6)$, indicating that the highest level of influence of government is reached at that point. In other words, the relationship between firm engagement in sustainability and government stakeholder influence is increasingly effective as government strength increases to the point at which ERRI reaches 0.91 . After this point, increasing the strength of government (as defined by the parameters used to calculate ERRI) begins to decrease the impact on firm engagement in sustainability. The findings suggest that there is an optimal level of government strength 
when the goal is influencing firm engagement in sustainability. With this caveat, hypothesis H1f was supported.

Additionally, the mean ERRI of the sample set was 0.47, indicating that there are potential opportunities in many of the countries studied in the sample set for greater government influence on firm engagement in sustainability through the strengthening of the regulatory environment as it relates to sustainability.

Overall, there was a positive correlation between government strength and firm engagement in sustainability $\left(\mathrm{R}^{2}=.058, \mathrm{~F}(2,397)=12.219, \mathrm{p}<.000\right)$, indicating that approximately $6 \%$ of the variation in firm engagement in sustainability could be explained by government as a stakeholder influencer, when not controlling for other factors. 


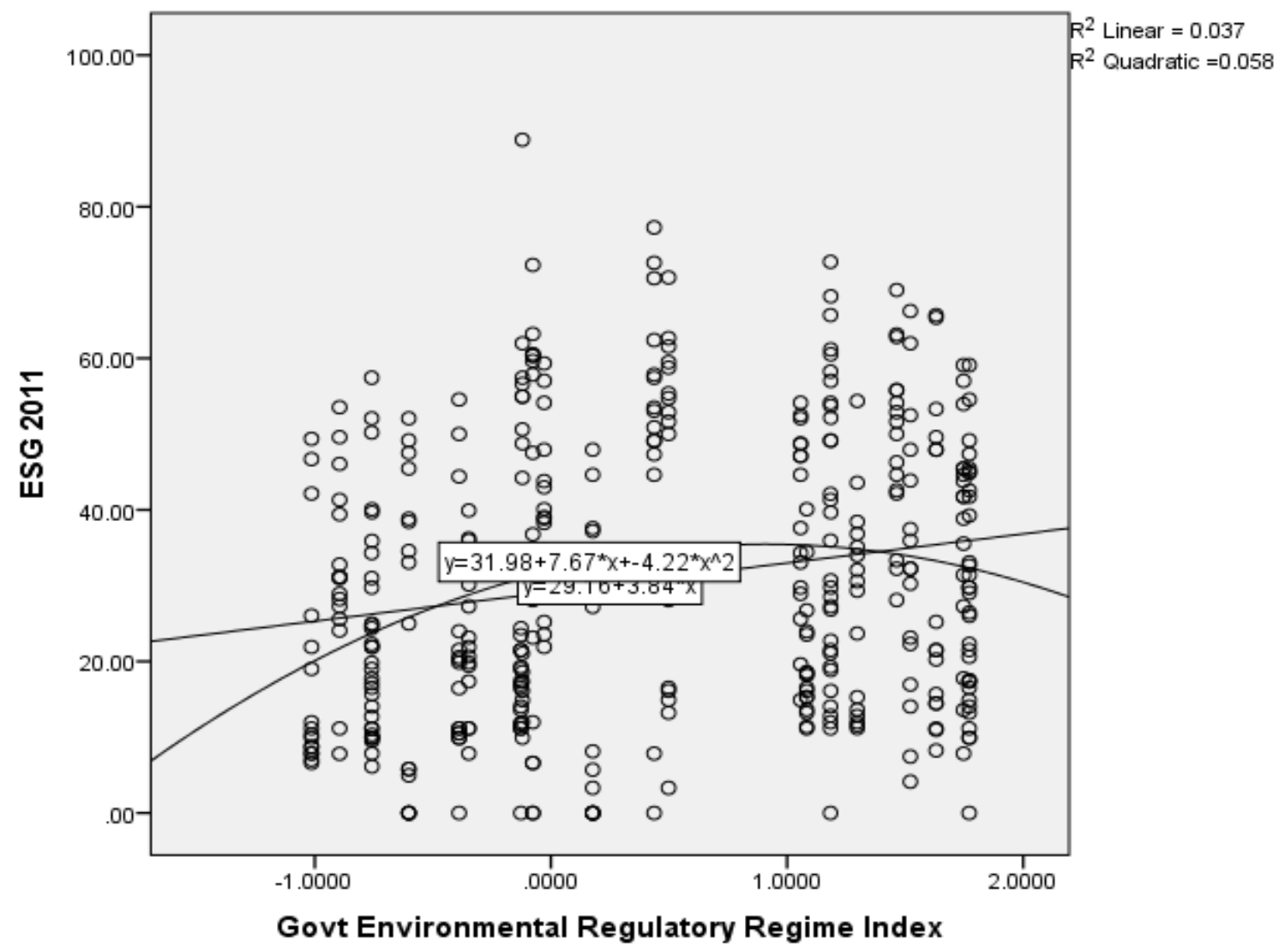

Figure 7. Scatter Plot of Government ERRI vs. ESG Disclosure Scores 


\section{Country Economy}

The economy of a country as a contextual factor was hypothesized to influence firm engagement in sustainability (H1g). Firms with headquarters in countries with lower GDP per capita PPP or that are considered developing economies were hypothesized to have lower levels of sustainability engagement. Country economy was investigated using two measures: (a) country GDP per capita PPP and (b) stage of economic development.

Using the first measure, a regression analysis indicated that GDP per capita PPP was significantly related to firm engagement in sustainability $(\mathrm{B}=.194, \mathrm{SE}=.058, \beta=$ $.164, \mathrm{p}<.001)$, indicating that firms with headquarters located in countries with higher GDP per capita PPP are more likely to have higher levels of engagement in sustainability when compared to firms in countries with lower GDP per capita PPP, supporting hypothesis $\mathrm{H} 1 \mathrm{~g}$.

Overall, there was a small positive correlation between GDP per capita PPP and firm engagement in sustainability $\left(\mathrm{R}^{2}=.027, \mathrm{~F}(1,398)=10.982, \mathrm{p}<.001\right)$, indicating that approximately $3 \%$ of the variation firm engagement in sustainability could be explained by the influence of GDP per capita PPP, when not controlling for other factors.

The second measure, stage of economic development, was used to test for differences among developed, rapidly developing and other developing economies. ${ }^{28}$ Results of a one-way ANOVA indicated that firm engagement in sustainability differed significantly among the three stages of economic development $(\mathrm{F}(2,397)=24.10, \mathrm{p}<$ .000), again supporting hypothesis H1g.

\footnotetext{
${ }^{28}$ See Table 12
} 
Tukey and Games-Howell post hoc tests indicated that firm engagement in sustainability differed significantly for firms with headquarters located in developed economies $(\mathrm{M}=35.51)$ when compared to firms with headquarters located in rapidly developing economies $(\mathrm{M}=29.75, \mathrm{p}<.05)$ and when compared to firms with headquarters located in other developing economies $(M=19.65, \mathrm{p}<.000)$. Sustainability engagement of firms with headquarters located in rapidly developing countries also differed significantly from firms with headquarters located in other developing economies $(\mathrm{p}<.000)$.

Firms with headquarters located in developed economies were approximately $19 \%$ more engaged in sustainability compared to firms in BRIICS countries (rapidly developing economies) and approximately $81 \%$ more engaged in sustainability compared to other developing economies. Table 21 is a summary of the ANOVA statistics of country economy influence as measured by stage of economic development on firm engagement in sustainability. 
Table 21

ANOVA Statistics of Country Economy Influence on Firm Engagement in Sustainability as Measured by Stage of Economic Development

\begin{tabular}{|c|c|c|c|}
\hline $\begin{array}{l}\text { Stage of Economic } \\
\text { Development }\end{array}$ & $\begin{array}{l}\text { Firm } \\
\text { Sustainability } \\
\text { Engagement } \\
\text { (Mean ESG Score) }\end{array}$ & $\begin{array}{l}\text { Standard } \\
\text { Deviation }\end{array}$ & $\mathbf{N}$ \\
\hline Developed economies ${ }^{* \wedge}$ & $35 \cdot 51$ & 18.70 & 224 \\
\hline $\begin{array}{l}\text { Rapidly developing economies }{ }^{\wedge} \\
\text { (BRIICS countries) }\end{array}$ & 29.75 & 16.56 & 96 \\
\hline Other developing economies ${ }^{\star} \#$ & 19.65 & 15.73 & 80 \\
\hline Sample Set & 30.95 & 18.64 & 400 \\
\hline
\end{tabular}

*Pair comparison significant, $\mathrm{p}<.000$

${ }^{\wedge}$ Pair comparison significant, $\mathrm{p}<.000$

\#Pair comparison significant, $\mathrm{p}<.000$ 


\section{Country Technological Readiness}

Availability of productivity technology in a country was hypothesized to influence firm engagement in sustainability as a contextual factor. Firms with headquarters in countries lacking adequate productivity technology were hypothesized to have lower levels of sustainability engagement $(\mathrm{H} 1 \mathrm{~h})$.

A regression analysis indicated that the availability of productivity technology in a country, as measured by the country's GCI technological readiness score, was significantly related to firm engagement in sustainability $(B=4.49, \mathrm{SE}=0.914, \beta=$ $0.239, \mathrm{p}<.000)$, indicating that firms with headquarters located in countries with better availability of productivity technology are more likely to have higher levels of sustainability engagement than firms in countries that have less availability of productivity technology, supporting hypothesis H1h.

Overall, there was a positive correlation between availability of productivity technology and firm engagement in sustainability $\left(\mathrm{R}^{2}=.057, \mathrm{~F}(1,398)=24.15\right.$, $\mathrm{p}<$ .000 ), indicating that approximately $6 \%$ of the variation firm engagement in sustainability could be explained by this factor, when not controlling for other factors. 


\section{Country Fossil Fuel Dependence}

Fossil fuel dependence as a contextual factor was hypothesized to influence firm engagement in sustainability. Firms with headquarters in countries that have higher dependence on fossil fuels for energy were hypothesized to have lower levels of sustainability engagement (H1i).

A regression analysis indicated that a country's fossil fuel dependence was significantly related to firm engagement in sustainability $(B=-.140, \mathrm{SE}=0.032, \beta=-$ $.215, \mathrm{p}<.000)$, indicating that firms with headquarters located in countries that have higher dependence on fossil fuels, as measured by percentage of electricity generated by fossil fuels in the country, are more likely to have lower levels of sustainability engagement than firms with headquarters located in countries that are less dependent on fossil fuels. Hypothesis H1i was supported.

Overall, there was a negative correlation between fossil fuel and firm engagement in sustainability $\left(\mathrm{R}^{2}=.046, \mathrm{~F}(1,398)=19.26, \mathrm{p}<.000\right)$, indicating that approximately $5 \%$ of the variation firm engagement in sustainability could be explained by country fossil fuel dependence, when not controlling for other factors. 


\section{Main Hypothesis Testing and Analysis}

In combination, stakeholders and contextual factors related to the firm and the country in which the firm has its headquarters were hypothesized to influence the firm's major strategic decisions with respect to engagement in sustainability.

A comprehensive study testing the main hypothesis was conducted using multiple regression. The comprehensive study investigated the combined effect of the stakeholder influence factors and several of the contextual influence factors as related to firm engagement in sustainability. Included in the analysis were the three stakeholder influence factors and three contextual influence factors. Executive management, community and government were tested for the combined effect of stakeholder influence on firm engagement in sustainability when taking into account contextual influence factors of firm size, country technological readiness, and country fossil fuel dependence.

Three contextual influence factors were not included in the comprehensive analysis. Firm financial performance was not included because the initial individual screening provided non-significant results. Country economy was not included due to multi-collinearity effects with country technological readiness. Industry sector was not included due to a lack of a linear relationship with the dependent variable.

Results indicated that each stakeholder influence factor had an independent significant association with firm engagement in sustainability. Of note, the regression coefficient for government changed to a negative sign, indicating that there may be a suppression effect. If this is the case, then government may have a stronger effect than 
indicated by the individual regression analysis of this factor. This finding should be explored in greater depth in future research.

Firm size and technological readiness as contextual influence factors were also independently significantly associated with firm engagement in sustainability. Fossil fuel dependence was not significant. Table 22 is a summary of the regression statistics of the combined influence factors on firm engagement in sustainability.

Combined, the stakeholder and contextual influence factors in the comprehensive study showed a large correlation with firm engagement in sustainability $\left(\mathrm{R}^{2}=.255, \mathrm{~F}(6\right.$, $361)=20.568, p<.000$ ), indicating that approximately $26 \%$ of the variation in firm sustainability engagement could be explained by the combined influence of the factors tested. 
Table 22

Multiple Regression Statistics of the Relationships Between the Influence Factors and Firm Engagement in Sustainability

\begin{tabular}{|c|c|c|c|c|}
\hline & B & SE & $\beta$ & $\mathrm{p}$ \\
\hline \multicolumn{5}{|l|}{ Stakeholders } \\
\hline Executive management & 6.60 & 1.042 & 0.304 & $.000^{*}$ \\
\hline Community & 0.217 & 0.104 & 0.147 & $.038^{* * *}$ \\
\hline Government & -8.117 & 2.452 & -0.384 & $.001^{* *}$ \\
\hline \multicolumn{5}{|l|}{ Contextual Factors } \\
\hline Firm Size & 0.211 & 0.030 & 0.326 & $.000^{*}$ \\
\hline Country technological readiness & $9 \cdot 332$ & 2.172 & 0.482 & $.000^{*}$ \\
\hline Country fossil fuel dependence & -0.003 & 0.039 & -0.004 & .941 \\
\hline Number of cases & 368 & & & \\
\hline $\mathrm{R}^{2}$ & .255 & & & \\
\hline
\end{tabular}




\section{Chapter 5}

\section{Discussion}

Developing a better understanding of sustainability practices and the influences that encourage or discourage sustainability is increasingly important, given the enormous challenges that the world faces today. Climate change, depletion of natural resources, social unrest due to economic and lifestyle inequities are a few of the major threats to the long term viability of the planet. Businesses, governments, and communities may play very large and important roles in how these challenges will be met.

Developing deeper understanding of the factors that influence firm engagement in sustainability as strategic initiatives of corporate social responsibility was the major goal of this study. A major theoretical purpose was to contribute further evidence supporting stakeholder theory and to open additional pathways for studying the influence of stakeholders and other influences on corporate social responsibility. This study investigated whether variations existed in the levels of engagement in sustainability efforts across firms and the potential factors influencing those differences.

\section{Limitations of the Study}

This study had many limitations, including limitations regarding the measures, the individual factors that were investigated, and generalizability of the study. Most of the limitations will be discussed in the next section in order to provide sufficient context with the individual factor, as appropriate, and to give suggestions for future research, taking into account the specific limitation. There were two major limitations to the study. First, the number of stakeholders and contextual factors was relatively small, although all were 
chosen for relevancy to sustainability. The study focused on the single strategic issue of sustainability engagement to better understand whether stakeholders and/or contextual factors influence organizations with respect to sustainability engagement. There may be other important stakeholders or contextual factors that should be considered and that might change the results substantially. A second major limitation was that only the country in which a firm had its headquarters was considered for the country-related influence factors. In reality, large companies such as those represented in this study are often multi-national enterprises (MNE), subject to influences from the many countries in which they do business.

\section{Significance of the Research: Theoretical and Practical Considerations}

Stakeholders and contextual factors were shown to have influence on firm engagement in sustainability. The study indicated that approximately $26 \%$ of the variation in firm sustainability engagement was accounted for by the combined influence of executive management, government and community as stakeholder influences and firm size and country technological readiness as contextual factors. As studied individually, the influence factors were all significantly related to firm engagement in sustainability. The findings suggested that stakeholder and contextual influences are important factors when explaining the differences in firm engagement in sustainability and the large correlation indicates that stakeholder and contextual factors should be considered critical components impacting firm strategic decisions with respect to engagement in sustainability. 
The major goal this study was to develop greater understanding regarding the role of stakeholders and relevant contextual factors in influencing corporate strategic directions with respect to sustainability engagement. The fundamental research question was whether variation existed in the levels of sustainability engagement across firms and, more importantly, what factors might influence or account for the variation. Built into the study was the aspiration to contribute further evidence supporting stakeholder theory, including that assertion stakeholders may take actions or influence a firm to meet their needs (Frooman \& Murrell, 2005; Frooman, 1999).

As one of the major goals of this project, the main hypothesis was supported as stated that stakeholders and contextual factors related to the firm and the country in which the firm has its headquarters impact the firm's major strategic decisions with respect to sustainability engagement, thus supporting the general basis of stakeholder theory. However, there are some limitations for generalization because the parameters of the investigation were narrowed to the single strategic issue of firm engagement in sustainability. The stakeholder types included in the study were carefully chosen as having relevance and potential power and legitimacy to influence decisions on this issue in support of Mitchell et al.'s (1997) argument that stakeholders should meet at least one of three attributes of power, legitimacy and/or urgency. Power sources were defined as reward, coercive, legitimate, referent and expert (French \& Raven, 2006). The contextual factors studied were also screened for relevancy to sustainability as the strategic issue at stake. Generalization that strategic decisions are consistently influenced by stakeholders would need to be tested further with other strategic issues and more stakeholders. An 
important learning from the study, however, was that stakeholders that are relevant and have power and legitimacy regarding the specific strategic issue at stake have significant potential to influence the firm's strategic decision-making on that issue.

Sustainability is currently a high profile topic for businesses, communities and governments and the study had a goal of providing practical insights for enhanced business strategy formulation with respect to sustainability, government policy impacts on firm engagement in sustainability, and the effect of community values on sustainability and citizen-based advocacy. Following is a discussion of the significance and learning regarding the influence factors studied, including thoughts on potential pathways of influence. The study tested only whether stakeholder and contextual factor influences existed, leaving open for future investigations the question of how each influenced the firm and the potential pathways of influence. Limitations and suggested areas for future research are included within the context of a particular factor.

Sustainability efforts are sometimes criticized as window-dressing, with a common criticism being that tactical green-washing efforts are used solely to project a more positive image of a company as sustainable or responsible. Although there is some basis for this criticism and examples of green-washing may be relatively easy to find, superficial tactical efforts at sustainability are not what is meant by strategic engagement of sustainability within an organization. Rather, strategic engagement requires a business to deeply embed sustainability efforts throughout the organization as part of the firm's mission-critical activities. 
In this study, overt strategic support for sustainability by management was shown to be an indicator of greater sustainability engagement by an organization, as measured by ESG disclosure scores. Sustainability efforts are difficult to measure and the criteria for what counts may be uniquely related to a particular company or industry. ESG disclosure scores, however, provide some semblance of standard measures across companies, industries and countries. Transparency in reporting progress or slippage over time may be better enabled for assessment of criteria such as the amount of emissions as related to environmental sustainability or labor practices as related to social sustainability efforts. While ESG ratings are not a "true" measure of the actual sustainability initiatives of a firm, they may be useful indicators of the effectiveness of the company with respect to sustainability because of the parameters used and how the scores are calculated. ESG ratings are based on extra-financial measures of valuation risk and generally include evaluation of many data points derived from actual company information (Bloomberg, 2013). A key assumption for this study was that higher ESG disclosure scores indicated better firm sustainability engagement and performance, based on Bloomberg's assessment that higher ESG disclosure scores indicate lower valuation risk.

Explicit discussion of the strategic importance of sustainability by executive management in a public company record (annual report) was significantly associated with higher engagement in sustainability. Executive managers are generally responsible for setting the strategic direction of the firm and have substantial influence for the broad strategic decisions of the firm through legitimate, reward and coercive power. Building 
sustainability initiatives and practices into firm strategy formalizes sustainability as part of mission-critical activities considered crucial to the success of the company.

The motivation of executive managers to engage in sustainability efforts may be strategic, instrumental or normative in nature. A potential pathway of influence of those executive managers who explicitly show strategic support for sustainability engagement is through greater investment of company resources targeted at sustainability-related initiatives. In addition, what is measured is often what gets attention, and management support for transparently measuring sustainability efforts while taking a strategic stand that sustainability is an important strategic direction of the firm may provide another pathway of influence by serving to encourage employees, shareholders and other relevant entities and stakeholders to support and engage in sustainability efforts.

As key stakeholders of influence in an organization, executive managers aspiring to improve sustainability engagement may benefit from explicitly planning for and committing to strategic change with respect to sustainability. Generally, common recommendations for leading strategic change include committed engagement by executive management for driving the change throughout the organization. Commitment and alignment of the organization and incorporation of standards to measure achievements toward strategic goals provide discipline and feedback that better enable successful strategic execution (Kaplan \& Norton, 2001; Parnell, 2014). Incorporating sustainability goals deeply into the strategic planning process and executive commitment to sustainability may lead to greater overall sustainability engagement across the organization. 
Porter \& Kramer (2011) provided a re-conceptualization of corporate social responsibility as shared value, described as connecting company success with social progress, i.e., looking for new approaches that generate innovation and growth for companies while also benefitting society, thereby expanding the total pool of economic and social value. They argue that “...addressing societal harms and constraints does not necessarily raise costs for firms, because they can innovate through using new technologies, operating methods, and management approaches - and as a result, increase their productivity and expand their markets (Porter \& Kramer, 2011, p. 5)." Shared value is a potentially useful conceptual framework for a firm to envision a deep strategic approach to sustainability, in ways that benefit both the organization and society. In practice, a beginning point for firms wanting to increase strategic engagement in sustainability might be to study the efforts of companies such as GE, Google, IBM, Intel, Johnson \& Johnson, Nestle, Unilever, and Walmart - firms identified as embarking on “...important efforts to create shared value by reconceiving the intersection between society and corporate performance (Porter \& Kramer, 2011, p. 4).”

Strategically engaging in sustainability initiatives most likely requires substantial investments of resources, potential restructuring of processes, new approaches to innovation and other activities that, in the short term, may impact financial performance. The results of this study did not show a significant association between financial performance and engagement in sustainability, and as discussed previously, other studies on this particular topic have shown mixed results. The current study, however, evaluated financial performance using only three measures - ROA, ROE and EBITDA - and only in 
the same fiscal year as sustainability engagement performance. The results notwithstanding, there may be a lag effect in financial performance when investing in sustainability efforts. Future research exploring financial performance with additional metrics for several years subsequent to major investments in sustainability initiatives may provide greater insights into the effects of sustainability engagement on financial performance.

A few of the instrumental reasons that firms engage in sustainability are enhanced competitive advantage or as a cost of doing business to remain competitive (Baldinger \& Nothiger, 2011; KPMG, 2011; Tullis, 2011). This raises a question of whether a tipping point is in sight whereby engagement in sustainability becomes a standard practice as the cost of doing business. In this study, firm size, as measured fiscal year revenue, was significantly related the firm engagement in sustainability, with larger firms tending to have higher engagement in sustainability. Larger companies tend to have greater availability of resources and it is possible that sustainability decisions may be easier to make simply based on the ability to fund initiatives or to have the resources to engage in such activities. Larger firms also tend to have larger workforces, may be more visible as targets, and, in the case of multinational enterprises, may have operations in many countries around the world, which may be substantial influence factors in themselves.

More importantly, however, larger firms have the ability to dominate the industries in which they engage and are potential influencers of behavior and the standards against which other companies compete for market share. An interesting question for future research is if and when a tipping point may occur in which 
sustainability engagement becomes standard practice for firms of any size. The variation in average ESG disclosure scores among the firms in the twenty-five countries represented in the study does not support an assertion that standard practice of sustainability will occur in the near future. Simply looking at country variation alone showed that ESG disclosure scores for firms tended to be the highest in several European countries with profiles as developed economies and the lowest in several South American and Asian countries with profiles as developing economies. There was also significant variation for firms by industry sector with energy-related and industrial sector firms tending toward higher ESG ratings and service industries such as real estate, financial services and media tending toward lower ESG ratings. If a tipping point is reached, it may be at the country or industry level, with barriers to entry increasing for firms that are unable to reach expected standards at the country level or for a particular industry sector, for example. It remains important and supported by the results of this study that executive managers be aware that the pressures to engage in responsible sustainable manner to stay competitive may only increase, particularly as the influence of industry leaders accumulates and transparent reporting and assignment of sustainability awards increases awareness of those companies that are progressing in sustainability efforts.

An unexpected result of this study was the higher engagement in sustainability for firms in the Oil \& Gas, Industrial, Utilities and Chemicals industry sectors. The results appear to be either anomalous with or a potential result of the reported environmental damage costs in 2008 for the Electricity, Oil \& Gas Producers, Industrial Metals \& Mining industry sectors, which accounted for nearly US\$1 trillion or $15 \%$ of the total 
worldwide environmental externality costs of US\$6.6 trillion (UNEP et al., 2011). These sectors, generally, have been under substantial scrutiny by the public, particularly framed by disasters such as the BP-operated Deepwater Horizon oil spill in 2010. Being identified as the industry sectors most responsible for environmental damage and high profile disasters and mishaps may have increased consumer and public pressure to provide enough motivation to the firms in these sectors to improve sustainability efforts. On the other hand, there may simply be greater opportunities for sustainability improvements compared to other industry sectors due to the nature of these industries and the impacts that they have, for example, on air and water pollution and other natural resource depletion.

In comparison, firms in service-oriented industry sectors - Real Estate, Financial Services, and Media - were found to have the lowest engagement in sustainability. Service industries are usually customer-facing and/or dependent on customer service as a differentiation factor and one might expect higher engagement in sustainability simply based on the amount of media attention given to topics such as climate change and other sustainability-related topics. Indeed, more consumers today seek out knowledge of the sustainability footprints of companies, with some customer segments having buying habits linked to purchasing from sustainably responsible companies. Service industry firms may have substantial opportunities to take advantage of the positive impact on reputation that higher engagement in sustainability could bring, potentially enhancing individual firm competitive advantage. Differences between high and low sustainability engagement by industry sector could be accounted for by industry norms or industry- 
unique reporting indicators, a potentially fruitful investigation topic for future consideration. Future research delving more deeply into industry factors, including investigation of intense public scrutiny, high profile disasters, industry structure and other industry-unique factors could shed more light on these somewhat anomalous results.

Business today is globalized, even for businesses that do not overtly seek to engage in the global marketplace. As an example, in a medium-sized town in Oregon a small coffee shop is located in the center of town, catering to the local community. Customers include faculty and students from the local university just down the street. On any given day, people from China, Canada, Nigeria, Kenya, Japan, the United States and other countries purchase coffee brewed from beans that are most likely sourced from multiple countries around the world. Differences in attitudes, behaviors, cultural expectations and other factors influence this small coffee shop to have a wide variation in products catering to many tastes.

Worldwide interest in sustainability has arisen on the back of issues such as climate change, labor conditions, and social unrest - issues that transcend national borders. This study showed, however, that there was significant variation in sustainability engagement depending on the country in which a firm's headquarters were located. Specific factors studied showed that country variation in firm engagement in sustainability could be accounted for by country-specific factors such as governmental strength, community societal norms, economic imperatives, availability of technology and fossil fuel dependence. 
Stage of economic development, technological readiness ${ }^{29}$ and fossil fuel dependence were significant country factors influencing firm engagement in sustainability. Particularly noteworthy were firms in developing economies that tended to have significantly lower levels of sustainability engagement compared to firms in developed economies. However, firms in the BRIICS countries, considered to be rapidly developing economies, had significantly higher engagement in sustainability compared to firms in other developing countries, suggesting that sustainability engagement increases as economic conditions improve in a country. The dividing lines between developing and developed countries on social and economic development issues and environmental stress include concerns about foregoing economic development as a cost of environmental stewardship (Axelrod, Vandeveer, et al., 2011; Najam, 2011). Firms with headquarters in countries that had better technological readiness tended to have higher levels of sustainability engagement. The lack of adequate technological infrastructure, or technological readiness, may preclude considerations of sustainability if building investments in technological capacity is of higher priority or if the capability does not exist to address sustainability issues. Fossil fuel dependence, on the other hand, was negatively associated with firm engagement in sustainability, suggesting that for firms

\footnotetext{
${ }^{29}$ Note: Technological readiness is a term used to describe “...the agility with which an economy adopts existing technologies to enhance the productivity of its industries, with specific emphasis on its capacity to fully leverage information and communication technologies in daily activities and production processes for increased efficiency and enabling innovation for competitiveness (Schwab, 2012, p. 6).” The World Economic Forum produces The Global Competitiveness Report annually that provides detailed assessments of the productive potential of nations worldwide. Technological readiness is one of the attributes used as a measure for the productivity potential of a country. See Appendix $\mathrm{G}$ for more information on The Global Competitiveness Report. Available from http://www.weforum.org/reports/global-competitiveness-report2011-2012.
} 
with headquarters in countries that have a high dependence on fossil fuels, sustainability efforts may be impacted. Sustainability efforts often include pollution and emissions controls that may be more difficult to accomplish in countries with substantial dependency on fossil fuels. This measure had substantial limitations because it was based on only on the percentage of electricity generated by fossil fuels.

As institutions with capabilities to influence business firms, communities and governments were significant factors in firm level of sustainability engagement. Community stakeholder influence, as measured by cultural values regarding sustainability and the propensity for citizen-based political action, was found to be significantly associated with firm engagement in sustainability. Communities are informal institutions that have access to referent and coercive power and the legitimacy to influence firms as stakeholders through norms and expectations of social behavior. Higher positive norms regarding sustainability and citizen-based political action were associated with higher levels of firm engagement in sustainability.

Firms are embedded in communities as societal and institutional environments and are subject to the expectations and standards of behaviors created through norms (Logsdon \& Yuthas, 1997). Under conditions of strong supportive societal norms for sustainability, firm dependence on the community may be a strong normative pathway of influence that encourages a firm to "do the right thing" with respect to sustainability, including going beyond solely complying with regulations related to sustainability. Businesses depend on communities and societies for approbation, good will, reputation and sales. Societal norms and expectations vary geographically, by country, by region 
and by local communities. Societal norms in combination with citizen-based political action may act as powerful stakeholders influencing a firm's behavior, as supported by the results of this study. A higher propensity for citizen-based political action may serve to encourage citizens of the community to actively influence firms to support sustainability. As a practical example, protests and boycotts about labor practices at Nike's contract factories in Indonesia and other countries in the 1990s led to Nike's commitment to improving working conditions in the factories and other initiatives aimed at increasing corporate responsibility in the larger community (Paine, Hsieh, \& Adamsons, 2013). Demonstrations, petitions or boycotts of firms to address a sustainability issue may heighten public awareness of a firm's culpability and escalate negative public perceptions regarding a firm. The desire of a firm to protect its reputation and image may provide communities with a significant pathway of influence.

As a significant indicator for firm engagement in sustainability, a country's propensity for citizen-based political action supports the notion that community engagement can make a significant difference in how businesses behave, and, more generally, on important societal issues and concerns. A democratic ability to engage in demonstrations, petitions or boycotts was found to be a useful determinant of how business behavior regarding an important societal issue can be influenced.

Although this research project focused solely on the country in which a firm's headquarters are located, the results are indicators of the importance of understanding the cultural milieu of the countries' in which a firm is doing business. Best practices for global business strategy encourage business managers to develop deep understanding of 
cultural, political, economic, social and technological factors before market entry into a country outside of domestic borders (Czinkota et al., 2009; Daniels, Radebaugh, \& Sullivan, 2011; Deresky, 2008; Peng, 2009; Thomas, 2002). This research supports that view. Because sustainability is a relatively high profile topic in the media that has heightened public awareness through discussions about climate change, human rights and other issues, a firm's due diligence for global strategy should include considerations of local sustainability concerns and issues prior to market entry. A major assumption and limitation of this study was that the influence of societal norms on a business is most pronounced in the home country or the country in which the firm has its headquarters. Future research investigating the impact of multiple countries in which a firm does business is warranted to develop clearer understanding of the differences in societal pressures that a firm may encounter and that may influence firm engagement in sustainability. In addition, delving more deeply into country-specific factors or learning from firms in countries with a tendency toward higher engagement in sustainability would be a worthwhile research undertaking for the future.

Government as a stakeholder influence was significantly related to firm engagement in sustainability. Institutional theory has a core argument that organizations seek legitimacy within their environments and are influenced by the institutional settings in which they operate (Dimaggio \& Powell, 1991; Doh \& Guay, 2006; Tolbert \& Zucker, 1996). As formal institutions, governments have access to power and legitimacy to influence businesses through coercive means such as regulatory requirements or through 
reward power such as providing incentives such as subsidies for firms to engage in sustainability.

Businesses are dependent on government for the ability to legally operate the company. Governments have the power to wield influence through several potential pathways. Coercive power of regulations and compliance mechanisms, such as loss of a business license or payment of fines for non-compliance are potential pathways of influence that may lead a firm to increase sustainability efforts for defensive or reputational reasons. Legal compliance is usually considered a minimal level of firm responsibility but a firm may choose to increase sustainability efforts beyond compliance for reasons as varied as increasing competitive advantage, enhancing the firm's reputation, meeting social pressures to go beyond compliance as a show of responsible corporate citizenship, or as a defensive measure to prevent further increases in the regulatory burden by showing the firm's willingness to take on higher levels of social responsibility through voluntary rather than coercive means. Lax regulatory regimes, on the other hand, may influence firms to ignore or disregard compliance with regulation requirements or to place a low value on sustainability needs, possibly leading to minimization of voluntary socially responsible activities that are beyond mission-critical activities.

The results of this study indicated an optimal level of government strength for influencing firm engagement in sustainability. Sustainability engagement increased with stronger government mechanisms to a certain point but then diminished, suggesting that there may be a point after which strengthening government further is not helpful. 
Government stakeholder influence was measured using the Environmental Regulatory Regime Index (ERRI) for each country, as developed by Esty \& Porter (2005). The curvilinear nature of the relationship between government and firm engagement in sustainability suggested that there is an optimal level of government strength that will be of most benefit in influencing sustainability engagement. Up to a certain point (measured as 0.91 ERRI), firms with headquarters in countries with stronger governmental institutions, actions, and preferences with respect to sustainability issues tended to have higher levels of sustainability engagement. As government strength increased beyond this point, the influence on firm engagement in sustainability declined.

ERRI scores are based on a complex mix of regulatory and institutional criteria including the regulatory structure; stringency of standards; regulatory enforcement; subsidies; institutional capacity; information availability; and administrative, scientific and technical infrastructures (Esty \& Porter, 2005, Figure 1, p. 395). The measure was very useful as a screening mechanism for government stakeholder influence and provided interesting and intriguing results but its complexity does not allow for granular views into the relative importance of regulations compared to subsidies, for example, as key influence factors on firm engagement in sustainability. By using ERRI as a measure, a door has opened for deeper questions on the interplay of the mix of capabilities that governments have at their disposal. Future research dissecting governmental capabilities to study the individual impact of each capability on businesses would potentially provide valuable insights into the relative effectiveness of each as influencers on firm engagement in sustainability. For example, an intriguing research question is if the influence on firms 
is more pronounced using subsidies or through stricter enforcement of regulations. The difficulty will be finding appropriate measures, especially for globally-focused studies.

The mean ERRI of the sample set was 0.47 and optimization was reached at ERRI equal to 0.91 , indicating that there is potential opportunity for many of the countries studied to increase the effectiveness of government capabilities should greater influence on firm engagement in sustainability be desired. Possible actions may include policy improvements in regulatory and compliance standards, increased subsidies for sustainability-related work, or increased private-public partnerships. An example of private-public partnerships resulting in combined business and social benefits, is the work that Microsoft, IBM, GE, Proctor \& Gamble and other firms are doing in partnership with public schools to bolster STEM oriented education. Still relatively small in scale but with encouraging results, these public-private partnerships are simultaneously addressing gaps in public funding for technology-based education while addressing industry skilled-labor shortages and helping to build a stronger middle class that will be future consumers of company products (Foroohar, 2014). The social benefits of adding to an educated populace are combined with benefits for businesses and governments. 


\section{References}

Abbott, Walter, F., \& Monsen, R. J. (1979). On the measurement of corporate social responsibility: Self-reported disclosures as a method of measuring corporate social involvement. The Academy of Management Journal, 22(3), 501-515.

Axelrod, R., Schreurs, M., \& Vig, N. (2011). Environmental policy making in the European Union. In The global environment: Institutions, law, and policy (3rd ed.). Washington, DC: CQ Press.

Axelrod, R., Vandeveer, S., \& Downie, D. (2011). The global environment: Institutions, law, and policy. The global environment: Institutions, law, and policy (3rd ed.). Washington, DC: CQ Press.

Balcom, S., \& Rawlins, B. (2010). Do the right thing: Measuring the effectiveness of corporate social responsibility. Tactics, 10-11.

Baldinger, M., \& Nothiger, M. (2011). The sustainability yearbook 2011 (pp. 1-118).

Baron, D. P., Harjoto, M. A., \& Jo, H. (2008). The economics and politics of corporate social performance (pp. 1-54).

Baughn, C. C., Bodie, N. L., \& Mcintosh, J. C. (2007). Corporate social and environmental responsibility in Asian countries and other geographical regions. Corporate Social Responsibility and Environmental Management, 14, 189-205. doi:10.1002/csr 
Berman, S. L., Wicks, A. C., Kotha, S., \& Jones, T. M. (1999). Does stakeholder orientation matter? The relationship between stakeholder management models and firm financial performance. Academy of Management Journal, 42(5), 488-506.

Bloomberg. (2013). Look beyond: Bloomberg for environmental, social, governance data. Bloomberg. Retrieved from www.bloomberg.com

Blowfield, M. (2005). Corporate social responsibility -The failing discipline and why it matters for international relations. International Relations, 19(2), 173-191. doi:10.1177/0047117805052812

Bonabeau, E. (2002). Agent-based modeling: Methods and techniques for simulating human systems. PNAS, 99(3), 7280-7287.

Bowen, H. R. (1953). Social responsibilities of the businessman. New York, NY: Harper.

Brammer, S., Millington, A., \& Rayton, B. (2007). The contribution of corporate social responsibility to organizational commitment. International Journal of Human Resource Management, 18(10), 1701-1719.

Brown, H. S., de Jong, M., \& Levy, D. L. (2009). Building institutions based on information disclosure: lessons from GRI's sustainability reporting. Journal of Cleaner Production, 17, 571-580. doi:10.1016/j.jclepro.2008.12.009 
Campbell, J. L. (2007). Why would corporations behave in socially responsible ways? An institutional theory of corporate social responsibility. Academy of Management Review2, 32(3), 946-967.

Carroll, A. B. (1979). A three-dimensional conceptual model of corporate performance. The Academy of Management Review, 4(4), 497-505.

Carroll, A. B. (1999). Corporate social responsibility: Evolution of a definitional construct. Business \& Society, 38(3), 268-295.

Coffey, B. S., \& Wang, J. (1998). Board diversity and managerial control as predictors of corporate social performance. Journal of Business Ethics, 17, 1595-1603.

Cottrill, M. T. (1990). Corporate social responsibility and the marketplace. Journal of Business Ethics, 9(9), 723-729.

Cumming, J. F., Bettridge, N., \& Toyne, P. (2005). Responding to global business critical issues: A source of innovation and transformation for FTSE 350 companies. Corporate Governance - The International Journal of Business in Society, 5(3), 4251.

Czinkota, M. R., Ronkainen, I. A., \& Moffett, M. H. (2009). Fundamentals of international business. Bronxville, NY: Wessex, Inc.

Daniels, J., Radebaugh, L., \& Sullivan, D. (2011). International business: Environments and operations (13th ed.). Upper Saddle River, NJ: Prentice Hall. 
David, F. R. (2011). Strategic management (13th ed.). Upper Saddle River, NJ: Prentice Hall.

De-los-Angeles Gil-Estallo, M., Giner-de-la-Fuente, F., \& Griful-Miquela, C. (2009). Benchmarking corporate social responsibility within Spanish companies. International Advances in Economic Research, 15(2), 207-225.

Deresky, H. (2008). International management: Managing across borders and culture. Upper Saddle River, NJ: Pearson.

Dimaggio, P. J., \& Powell, W. W. (1991). New institutionalism and organizational analysis. Chicago: University of Chicago Press.

Dixon, R. K. (2007). Advancing towards a hydrogen energy economy: Status, opportunities and barriers. Mitigation \& Adaptation Strategies for Global Change, $12,325-341$.

Doh, J. P., \& Guay, T. R. (2006). Corporate social responsibility, public policy , and NGO activism in Europe and the United States: An institutional-stakeholder perspective. Journal of Management Studies, 43(1), 47-73.

Donaldson, T., \& Preston, L. E. (1995). The stakeholder theory of the corporation: Concepts, evidence, and implications. Academy of Management Review, 20(1), 6591. 
Esty, D. C., \& Porter, M. E. (2005). National environmental performance: An empirical analysis of policy results and determinants. Faculty Scholarshop Series, Paper 430. doi:10.1017/S1355770X05002275

Feiock, R. C., Moon, M. J., \& Park, H. J. (2008). Is the world "flat" or "spiky"? Rethinking the governance implications of globalization for economic development. Public Administration Review, 68(1), 1-19.

Feltrin, A., \& Freundlich, A. (2008). Material considerations for terawatt level deployment of photovoltaics. Renewable Energy: An International Journal, 33, $180-185$.

Foroohar, R. (2014). The school that will get you a job: A new kind of education shows why four years of high school isn't enough. Time Magazine.

Frederick, W. C. (1994). From CSR1 to CSR2. Business \& Society, 33, 150-164.

Frederickson, H. G. (2004). Whatever happened to public administration: governance, governance everywhere. In ASPA Conference. Portland, OR.

Freeman, R. (1984). Strategic management: A stakeholder approach. Boston, MA: Pitman.

Freeman, R. (2010). Managing for stakeholders: Trade-offs or value creation. Journal of Business Ethics, 96, 7-9. doi:10.1007/s10551-011-0935-5 
Freeman, R., Bowie, N., Wicks, A., Werhane, P., Martin, K., Harrison, J., \& Hitt, M. (2013). Managing for stakeholders. Darden Business Publishing, (UVA-E-0383), 116.

French, J. R. P., \& Raven, B. (2006). The bases of social power. In J. Pierce \& J. Newstrom (Eds.), Leaders \& the leadership process (4th ed., pp. 146-152). New York, NY: McGraw-Hill.

Frooman, J. (1999). Stakeholder influence strategies. The Academy of Management Review, 24(2), 191-205.

Frooman, J., \& Murrell, A. J. (2005). Stakeholder influence strategies: The roles of structural and demographic determinants. Business \& Society, 44, 3-31. doi: $10.1177 / 0007650304273434$

Galaskiewicz, J. (1997). An urban grants economy revisited: Corporate charitable contributions in the Twin Cities, 1979-1981, 1987-1989. Administrtive Science Quarterly, 42, 445-471.

Garcia-Castro, R., Arino, M., \& Canela, M. (2010). Does social performance really lead to financial performance? Accounting for endogeneity. Journal of Business Ethics, 92(1), 107-126.

Garriga, E., \& Mele, D. (2004). Corporate social responsibility theories: Mapping the territory. Journal of Business Ethics, 53, 51-71. 
Gauthier, C. (2005). Measuring corporate social and environmental performance: The extended life-cycle assessment. Journal of Business Ethics, 59(1/2), 199-206. doi:10.1007/s10551-005-3416-x

Gilau, A. M., Van Buskirk, R., \& Small, M. J. (2007). Enabling optimal energy options under the Clean Development Mechanism. Energy Policy, 35, 5526-5534.

Gilbert, N. (2008). Agent-based models. Thousand Oaks, CA: Sage Publications.

Gilpin, R. (2002). A realist perspective on international governance. In D. Held \& A. McGrew (Eds.), Governing globalization: Power, authority and global governance. Cambridge, UK: Polity Press.

Gjolberg, M. (2009). Measuring the immeasurable? Constructing an index of CSR practices and CSR performances in 20 countries. Scandinavian Journal of Management, 25(1), 10-22.

Gond, J.-P., \& Crane, A. (2008). Corporate social performance disoriented: Saving the lost paradigm? Business \& Society, 49(4), 677-703. doi: $10.1177 / 0007650308315510$

Green, D., \& Griffith, M. (2002). Globalization and its discontents. International Affairs, 78(1), 49-68.

GRI. (2011). Sustainability reporting guidelines, V.3.1. 
Guthrie, D. (2003). Survey on corporate-community relations. New York: Social Sciences Research Council.

Hendry, J. R. (2005). Stakeholder influence strategies : An empirical exploration. Journal of Business Ethics, 61(1), 79-99.

Hillman, A. J., Withers, M. C., \& Collins, B. J. (2009). Resource dependence theory: A review. Journal of Management, 35(6), 1404-1427. doi: $10.1177 / 0149206309343469$

Jamali, D. (2008). A stakeholder approach to corporate social responsibility. Journal of Business Ethics, 82(1), 213-231.

Jensen, M. C. (2002). Value maximization, stakeholder theory, and the corporate objective function. Business Ethics Quarterly, 12(2), 235-256.

Kanter, R. (1997). World class: Thriving local in the global economy. New York: Touchstone Books.

Kaplan, R. S., \& Norton, D. P. (2001). Transforming the balanced scorecard from performance measurement to strategic management: Part II. Accounting Horizons, 15(2), 147-160.

Kaygusuz, K. (2007). Energy for sustainable development: Key issues and challenges. Energy Sources Part B: Economics, Planning \& Policy, 2, 73-83. 
Keim, G. (2003). Nongovernmental organizations and business-government relations: The importance of institutions. In J. P. Doh \& H. Teegen (Eds.), Globalization and NGOs: Transforming business, governments, and society. Westport, CT: Praeger.

Keohane, R., \& Nye, J. (2001). Power and intedependence. New York, NY: Longman.

KPMG. (2011). KPMG international survey of corporate responsibility reporting 2011. Retrieved from http://www.kpmg.com/Global/en/IssuesAndInsights/ArticlesPublications/corporateresponsibility/Documents/2011-survey.pdf

Krahmann, E. (2003). National, regional and global governance: One phenomenon or many? Global Governance, 9, 323-346.

Laplume, A. O., Sonpar, K., \& Litz, R. a. (2008). Stakeholder theory: Reviewing a theory that moves us. Journal of Management, 34, 1152-1189. doi:10.1177/0149206308324322

Lerner, L. D., \& Fryxell, G. E. (1988). An empirical study of the predictors of corporate social performance: A multi-dimensional analysis. Journal of Business Ethics, 7, 951-959.

Logsdon, J. M., \& Yuthas, K. (1997). Corporate social performance, stakeholder orientation, and organizational moral development. Journal of Business Ethics, 16(12/13), 1213-1226. 
Luo, X., \& Bhattacharya, C. B. (2006). Corporate social responsibility, customer satisfaction, and market value. Journal of Marketing, 70, 1-18.

Margolis, J. D., \& Walsh, J. P. (2003). Misery loves companies: Rethinking social initiatives by business. Administrative Science Quarterly, 48, 268-305.

Marquis, C., Glynn, M. A., \& Davis, G. F. (2007). Community isomorphism and corporate social action. Academy of Management Review, 32(3), 925-945.

Mayo, A. J., \& Nohria, N. (2005). In their time: The greatest business leaders of the 20th century. Boston, MA: Harvard Business School Press.

McElroy, K. M., \& Siegfried, J. J. (1986). The community influence on corporate contributions. Public Finance Quarterly, 14, 394-414.

Mcguire, J. B., Sundgren, A., \& Schneeweis, T. (1988). Corporate social responsibility and firm financial performance. The Academy of Management Journal, 31(4), 854872.

McWilliams, A., \& Siegel, D. (2001). Corporate responsibility and financial performance: Correlation or misspecification? Academy of Management Review, 26(1), 117-127.

Mitchell, R. K., Agle, B. R., \& Wood, D. J. (1997). Toward a theory of stakeholder identification and salience: Defining the principle of who and what really counts. Academy of Management Review, 22(4), 853-886. 
Munilla, L. S., \& Miles, M. P. (2005). The corporate social responsibility continuum as a component of stakeholder theory. Business and Society Review, 110(4), 371-387. doi:10.1111/j.0045-3609.2005.00021.x

Murillo, D., \& Lozano, J. M. (2006). SMEs and CSR: An approach to CSR in their own words. Journal of Business Ethics, 67, 227-240. doi:10.1007/s10551-006-9181-7

Najam, A. (2011). The view from the South: Developing countries in global environmental politics. In R. Axelrod, M. Schreurs, \& N. Vig (Eds.), The global environment: Institutions, law, and policy. Washington, DC: CQ Press.

North, D. C. (1991). Institutions, institutional change and economic performance. Cambridge: Cambridge University Press.

North, D. C. (1994). Economic performance through time. The American Economic Review, 84, 359-68.

O’Higgins, E. R. E. (2010). Corporations, civil society, and stakeholders: An organizational conceptualization. Journal of Business Ethics, 94(2), 157-176. doi:10.1007/s 10551-009-0254-2

Paine, L. S., Hsieh, N., \& Adamsons, L. (2013). Governance and sustainability at Nike. Harvard Business School Publishing, 9-313-146.

Parnell, J. (2014). Strategic management: Theory and practice. Los Angeles: Sage Publications. 
Peloza, J. (2009). The challenge of measuring financial impacts from investments in corporate social performance. Journal of Management, 35(6), 1518-1541.

Peng, M. (2009). Global strategy (2nd ed.). Mason, OH: South-Western Cengage.

Pfeffer, J., \& Salancik, G. R. (1978). The external control of organizations: A resource dependency perspective. New York, NY: Harper \& Row.

Poddi, L., \& Vergalli, S. (2009). Does corporate social responsibility affect the performance of firms? In Coalition Theory Network Workshop. Maastricht, The Netherlands.

Porter, M. E., \& Kramer, M. R. (2011). Creating shared value. Harvard Business Review, (January-February).

Puncheva, P. (2008). The role of corporate reputation in the stakeholder decision-making process. Business \& Society, 47(3), 272-290. doi:10.1177/0007650306297946

Quattrone, G. A., \& Tversky, A. (1988). Contrasting rational and psychological analyses of political choice. American Political Science Review, 82(3), 719-736.

Robbins, S., DeCenzo, D., \& Coulter, M. (2011). Fundamentals of management. New York, NY: Prentice Hall.

Rosenbaum, W. A. (2011). Environmental politics and policy. Washington, DC: CQ Press. 
Schwab, K. (2012). The global competitiveness report. Geneva.

Sternberg, E. (1997). The defects of stakeholder theory. Corporate Governance, 5(1).

Sternberg, R. J. (1988). The triarchic mind: A new theory of human intelligence. New York, NY: Viking.

Sudaram, A. K., \& Inkpen, A. C. (2004). The corporate objective revisited. Organization Science, 15(3), 350-363.

Thomas, D. C. (2002). Essentials of international management. Thousand Oaks, CA: Sage Publications.

Tolbert, P. S., \& Zucker, L. G. (1996). The institutionalization of institutional theory. In S. R. Clegg, C. Hardy, \& W. R. Norde (Eds.), A handbook of organizational studies. London: Sage Publications.

Tsoutos, T., Frantzeskaki, N., \& Gekas, V. (2005). Environmental impacts from the solar energy technologies. Energy Policy, 33, 289-296.

Tullis, P. (2011, March). Bloomberg's push for corporate sustainability: Why Bloomberg broke into the business of measuring other companies' good deeds. Fast Company. Retrieved from http://www.fastcompany.com/1739782/bloombergs-push-corporatesustainability 
Turker, D. (2009). Measuring corporate social responsibility: A scale development study. Journal of Business Ethics, 85, 411-427. doi:10.1007/s 10551-008-9780-6

Übius, Ü., \& Alas, R. (2009). Organizational culture types as predictors of corporate social responsibility. Engineering Economics, 1(61), 90-99.

UNEP, PRI, \& Trucost. (2011). Why environmental externalities matter to institutional investors. Retrieved from http://www.unepfi.org/fileadmin/documents/universal_ownership_full.pdf

Votaw, D. (1972). Genius became rare: A comment on the doctrine of social responsibility. California Management Review, 15(2), 25-31.

Waldman, D. A., Siegel, D. S., \& Javidan, M. (2006). Components of CEO transformational leadership and corporate social responsibility. Journal of Management Studies, 43(8), 1703-1725. doi:10.1111/j.1467-6486.2006.00642.x

Waldman, D. A., Sully de Luque, M., Washburn, N., House, R. J., Adetoun, B., Barrasa, A.,Wilderom, C. P. M. (2006). Cultural and leadership predictors of corporate social responsibility values of top management: A GLOBE study of 15 countries. Journal of International Business Studies, 37, 823-837.

Wartick, S. L., \& Cochran, P. L. (1985). The evolution of the corporate social performance model. Academy of Management Review, 10(4), 758-769. 
Wilkes, V. (2005). Dealing with a global issue: Contributing to poverty alleviation. Corporate Governance - The International Journal of Business in Society, 5(3), 6169.

Winn, M. (2001). Building stakeholder theory with a decision modeling methodology. Business \& Society, 40(2), 133-166.

Wood, D. (1991). Corporate social performance revisited. The Academy of Management Review, 16(4), 691-717.

Wustenhagen, R., Wolsink, M., \& Burer, M. J. (2007). Social acceptance of renewable energy innovation: An introduction to the concept. Energy Policy, 35, 2683-2691. 
Appendices 


\section{Appendix A}

\section{DJSI Industry Classifications}

\section{DJSI SAM SuperSector (Industry Sector)}

Automobiles \& Parts

Banks

Basic Materials

Chemicals

Construction \& Materials

Financial Services

Food \& Beverage

Healthcare

Industrial Goods \& Services

Insurance

Media

\section{DJSI SAM} Sector Code
SAM Sector

Automobiles

Auto Parts \& Tires

Banks

Forestry \& Paper

Aluminum

Mining

Steel

CHM Chemicals

BLD Building Materials \& Fixtures

CON Heavy Construction

FBN Financial Services

BVG Beverages

FOA Food Producers

HEA Healthcare Providers

MTC Medical Products

BTC Biotechnology

DRG Pharmaceuticals

ARO

Aerospace \& Defense Containers \& Packaging

Diversified Industrials

Electronic Components \& Equipment

Electronic Equipment

Industrial Engineering

Industrial Transportation

Support Services

Waste \& Disposal Services

POL

INS

Insurance

PUB

Media 


\begin{tabular}{|c|c|c|}
\hline \multirow[t]{4}{*}{ Oil \& Gas } & OIX & Oil \& Gas Producers \\
\hline & OIE & Oil Equipment \& Services \\
\hline & PIP & Pipelines \\
\hline & $\mathrm{ALT}$ & Renewable Energy Equipment \\
\hline \multirow[t]{7}{*}{ Personal \& Household Goods } & DHP & Durable Household Products \\
\hline & $\mathrm{HOU}$ & Nondurable Household Products \\
\hline & FTR & Furnishing \\
\hline & HOM & Home Construction \\
\hline & LEG & Leisure Goods \\
\hline & TEX & Clothing, Accessories \& Footwear \\
\hline & $\cos$ & Personal Products \\
\hline Real Estate & REA & Real Estate \\
\hline \multirow[t]{3}{*}{ Retail } & FDR & Food \& Drug Retailers \\
\hline & RTS & General Retailers \\
\hline & CSV & Specialized Consumer Services \\
\hline \multirow[t]{6}{*}{ Technology } & TSV & Computer Services \& Internet \\
\hline & SOF & Software \\
\hline & THQ & Computer Hardware \& Electronic Office \\
\hline & SEM & Equipment \\
\hline & CMT & Semiconductors \\
\hline & & Communication Technology \\
\hline \multirow[t]{2}{*}{ Telecommunications } & FTS & Fixed Line Communications \\
\hline & CTS & Mobile Telecommunications \\
\hline \multirow[t]{4}{*}{ Travel \& Leisure } & AIR & Airlines \\
\hline & REX & Hotels, Restaurants, Bars \& Recreational \\
\hline & TRT & Services \\
\hline & & Travel \& Tourism \\
\hline \multirow[t]{3}{*}{ Utilities } & ELC & Electricity \\
\hline & GAS & Gas Distribution \\
\hline & WAT & Water \\
\hline
\end{tabular}

Source: The Dow Jones Sustainability World Index Guide, www.sustainability-index.com 


\section{Appendix B}

\section{Number of Firms in DJSI List by Country}

\begin{tabular}{|c|c|c|c|c|c|}
\hline Country & $\begin{array}{l}\text { Number of } \\
\text { Companies } \\
\text { in DJSI List }\end{array}$ & $\begin{array}{c}\% \text { of } \\
\text { DJSI } \\
\text { List }\end{array}$ & Country & $\begin{array}{l}\text { Number of } \\
\text { Companies } \\
\text { in DJSI List }\end{array}$ & $\begin{array}{c}\% \text { of } \\
\text { DJSI } \\
\text { List }\end{array}$ \\
\hline Argentina & 1 & $0.03 \%$ & Korea*, Republic of & 199 & $6.47 \%$ \\
\hline Australia* & 190 & $6.17 \%$ & Kuwait & 5 & $0.16 \%$ \\
\hline Austria & 8 & $0.26 \%$ & Malaysia* & 38 & $1.23 \%$ \\
\hline Bahrain & 1 & $0.03 \%$ & Mexico* & 27 & $0.88 \%$ \\
\hline Belgium & 15 & $0.49 \%$ & Morocco & 5 & $0.16 \%$ \\
\hline Brazil* & 91 & $2.96 \%$ & Netherlands* & 30 & $0.97 \%$ \\
\hline Canada* & 127 & $4.13 \%$ & New Zealand & 4 & $0.13 \%$ \\
\hline Chile* & 25 & $0.81 \%$ & Norway & 16 & $0.52 \%$ \\
\hline China* & 97 & $3.15 \%$ & Peru & 8 & $0.26 \%$ \\
\hline Colombia & 14 & $0.45 \%$ & Philippines* & 22 & $0.71 \%$ \\
\hline Czech Republic & 3 & $0.10 \%$ & Poland & 14 & $0.45 \%$ \\
\hline Denmark & 16 & $0.52 \%$ & Portugal & 7 & $0.23 \%$ \\
\hline Egypt & 3 & $0.10 \%$ & Qatar & 5 & $0.16 \%$ \\
\hline Finland & 19 & $0.62 \%$ & Russia* & 33 & $1.07 \%$ \\
\hline France* & 83 & $2.70 \%$ & Singapore* & 32 & $1.04 \%$ \\
\hline Germany* & 65 & $2.11 \%$ & Slovenia & 1 & $0.03 \%$ \\
\hline Greece & 2 & $0.06 \%$ & South Africa* & 64 & $2.08 \%$ \\
\hline Hong Kong^ & 47 & $1.53 \%$ & Spain* & 30 & $0.97 \%$ \\
\hline Hungary & 4 & $0.13 \%$ & Sweden* & 46 & $1.49 \%$ \\
\hline India* & 85 & $2.76 \%$ & Switzerland* & 53 & $1.72 \%$ \\
\hline Indonesia* & 29 & $0.94 \%$ & Thailand* & 22 & $0.71 \%$ \\
\hline Ireland & 8 & $0.26 \%$ & Turkey & 14 & $0.45 \%$ \\
\hline Israel & 6 & $0.19 \%$ & UAE & 3 & $0.10 \%$ \\
\hline Italy* & 29 & $0.94 \%$ & United Kingdom* & 179 & $5.82 \%$ \\
\hline Japan* & 317 & $10.30 \%$ & United States* & 935 & $30.38 \%$ \\
\hline Jordan & 1 & $0.03 \%$ & Total $^{\#}$ & 3078 & $100 \%$ \\
\hline
\end{tabular}

*Country included in sample set

$\wedge$ Hong Kong companies were included in the population set for China and had an equally random chance of being chosen for the China companies in the sample set

\#DJSI list of eligible companies total, after removing companies that had gambling or tobacco as the primary industry sector

Note: 51 countries are represented in the DJSI population.

Source: The Dow Jones Sustainability World Index Guide, www.sustainability-index.com 


\section{Appendix C}

\section{Bloomberg Environmental, Social and Governance Data Description for ESG Disclosure Scores}

The following information is a description of Bloomberg Environmental, Social and Governance Data, excerpted from Bloomberg's ESG brochure (Bloomberg, 2013).

Environmental, social and governance data, commonly referred to as ESG, are intangible, extra-financial measures of valuation risk derived from a company's operational decisions, HR policies and practices, and corporate governance structures. Investors and corporate executives are increasingly embracing the concept that ESG information resource efficiency, good community relations, training and developing the workforce, and board/committee structures, for example - may directly impact companies' reputation, value and performance. Governments, regulatory bodies and exchanges are encouraging more ESG data disclosure and, crucially, the standardization and verification of ESG data disclosure.

\section{ENVIRONMENTAL}

SOCIAL

GOVERNANCE

\begin{tabular}{ccc}
\hline $\begin{array}{c}\text { Risks created by } \\
\text { operational } \\
\text { decisions }\end{array}$ & $\begin{array}{c}\text { Risks arising from } \\
\text { corporate HR policies and } \\
\text { practices }\end{array}$ & $\begin{array}{c}\text { Risks stemming from flaws } \\
\text { in corporate governance } \\
\text { policies }\end{array}$ \\
Carbon emissions & Supply chain & Cumulative voting \\
Climate change effects & Discrimination & Executive compensation \\
Pollution & Political contributions & Shareholders' rights \\
Waste disposal & Diversity & Takeover defense \\
Renewable energy & Human rights & Staggered boards \\
Resource depletion & Community relations & Independent directors \\
& & \\
\hline
\end{tabular}

Bloomberg ESG data is collected from company-sourced filings such as Corporate Social Responsibility reports, annual reports, company websites and a proprietary Bloomberg survey that requests corporate data directly. Bloomberg has researched 20,000 companies worldwide across more than 50 countries, covering virtually the entire investable universe that disclose ESG data. None of this data is estimated or derived; every data field has transparency back to a company document.

Source: "Look beyond: Bloomberg for environmental, social and governance data, A Bloomberg Professional Service Offering”, Retrieved from Bloomberg terminal, April 28, 2013 


\section{Example of ESG Disclosure Score Data from Bloomberg Database}

\begin{tabular}{|c|c|c|c|c|}
\hline $\begin{array}{l}\text { Ticker } \\
\text { Company }\end{array}$ & $\begin{array}{l}\text { (Deleted by author of this study } \\
\text { for confidentiality purposes) } \\
\text { (Deleted) }\end{array}$ & & & \\
\hline $\begin{array}{l}\text { Field } \\
\text { For period ending }\end{array}$ & Mnemonic & $\begin{array}{l}\mathrm{FY} 2011 \\
12 / 31 / 2011 \\
\text { original }\end{array}$ & $\begin{array}{l}\mathrm{FY} 2010 \\
12 / 31 / 2010 \\
\text { original }\end{array}$ & $\begin{array}{l}\mathrm{FY} 2009 \\
12 / 31 / 2009 \\
\text { restated }\end{array}$ \\
\hline ESG Disclosure & & & & \\
\hline $\begin{array}{l}\text { Score } \\
\text { Environmental } \\
\text { Environmental }\end{array}$ & ESG_DISCLOSURE_SCORE & $33 \cdot 4711$ & 23.1405 & 11.9835 \\
\hline $\begin{array}{l}\text { Disclosure Score } \\
\text { Total } \mathrm{CO}_{2}\end{array}$ & ENVIRON_DISCLOSURE_SCORE & 25.5814 & 20.155 & 10.8527 \\
\hline $\begin{array}{l}\text { Emissions } \\
\mathrm{CO}_{2} \text { Intensity per }\end{array}$ & TOTAL_CO2_EMISSIONS & $\# N / A N / A$ & 764.462 & 363.748 \\
\hline $\begin{array}{l}\text { Energy } \\
\text { Total Energy }\end{array}$ & $\mathrm{CO}_{2}$ INTENSITY & $\# N / A N / A$ & 0.174 & 0.12 \\
\hline $\begin{array}{l}\text { Consumption } \\
\text { Water }\end{array}$ & ENERGY_CONSUMPTION & $\# N / A N / A$ & 4390.591 & 3019.694 \\
\hline $\begin{array}{l}\text { Consumption } \\
\text { Environmental }\end{array}$ & TOTAL_WATER_USE & $\# N / A N / A$ & 11866.717 & 7902.925 \\
\hline $\begin{array}{l}\text { Fines \# } \\
\text { Environmental }\end{array}$ & NUM_ENVIRON_FINES & 3 & $\# N / A N / A$ & $\# N / A N / A$ \\
\hline Fines $\$$ & ENVIRON_FINES_AMT & 0.05 & $\# N / A N / A$ & $\# N / A N / A$ \\
\hline $\begin{array}{l}\text { Social } \\
\text { Social Disclosure }\end{array}$ & & & & \\
\hline $\begin{array}{l}\text { Score } \\
\text { Number of }\end{array}$ & SOCIAL_DISCLOSURE_SCORE & 36.8421 & 19.2982 & 12.2807 \\
\hline $\begin{array}{l}\text { Employees } \\
\text { \% Employees }\end{array}$ & NUMBER_EMPLOYEES_CSR & 122000 & 123999 & 117311 \\
\hline $\begin{array}{l}\text { Unionized } \\
\text { Community }\end{array}$ & PCT_EMPLOYEES_UNIONIZED & 100 & $\# N / A N / A$ & $\# N / A N / A$ \\
\hline $\begin{array}{l}\text { Spending } \\
\text { Governance }\end{array}$ & COMMUNITY_SPENDING & 293.8 & $\# N / A N / A$ & 248 \\
\hline $\begin{array}{l}\text { Governance } \\
\text { Disclosure Score }\end{array}$ & & & & \\
\hline Disclosure Score & GOVNCE_DISCLOSURE_SCORE & 48.2143 & 33.9286 & 14.2857 \\
\hline Size of the Board & BOARD_SIZE & 6 & 6 & 6 \\
\hline Indep Directors & INDEPENDENT_DIRECTORS & 1 & $\# N / A N / A$ & $\# N / A N / A$ \\
\hline$\%$ Indep Directors & PCT_INDEPENDENT_DIRECTORS & 16.67 & $\# N / A N / A$ & $\# N / A N / A$ \\
\hline Political Donations & POLITICAL_DONATIONS & o & 24.459 & $\# N / A N / A$ \\
\hline
\end{tabular}

Source: Bloomberg; information retrieved from Bloomberg terminal, April 28, 2013 


\section{Appendix D}

\section{Government Environmental Regulatory Regime Index (ERRI) Basis}

\begin{tabular}{|c|c|c|c|c|}
\hline \multirow[b]{2}{*}{$\begin{array}{l}\text { Environmental } \\
\text { Performance } \\
\text { - Urban Particulate } \\
\text { Concentration } \\
\text { - Energy Usage per GDP } \\
\text { - Unit } \\
\text { Urban } \mathrm{SO}_{2} \text { Concentration }\end{array}$} & \multicolumn{4}{|c|}{ Environmental Regulatory Regime } \\
\hline & $\begin{array}{l}\text { Stringency of Standards } \\
\text { - Air regulation } \\
\text { - Water regulation } \\
\text { - Toxic waste regulation } \\
\text { - Chemical regulation } \\
\text { Regulatory Structure } \\
\text { - Options for compliance } \\
\text { - Confusing and changing } \\
\text { - Early or late } \\
\text { - Compliance hurts or helps } \\
\text { competitiveness } \\
\text { - Regulation adversarial or } \\
\text { cooperative }\end{array}$ & \multicolumn{2}{|c|}{$\begin{array}{l}\text { Information } \\
\text { - Tracking of ESI variables } \\
\text { - Availability of Sustainable } \\
\text { development information } \\
\text { - Number of sectoral EIA } \\
\text { guidelines } \\
\text { - Number of environmental } \\
\text { strategies \& action plans }\end{array}$} & $\begin{array}{l}\text { Environmental Institutions } \\
\text { - IUCN organizations per } \\
\text { million population } \\
\text { - Membership in } \\
\text { intergovernmental } \\
\text { environmental } \\
\text { organizations } \\
\text { - Prevalence of ISO } 14000\end{array}$ \\
\hline & \multicolumn{4}{|c|}{ Economic and Legal Context } \\
\hline $\begin{array}{l}\text { Economic } \\
\text { Competitiveness } \\
\text { - GDP Per Capita } \\
\text { - Growth } \\
\text { - Current Competitive Index }\end{array}$ & \multicolumn{2}{|c|}{$\begin{array}{l}\text { Administrative Infrastructure } \\
\text { - Civil Liberties } \\
\text { - Public Sector Competence } \\
\text { - Government Fairness in Treatment of Private } \\
\text { Sector } \\
\text { - Property Rights } \\
\text { - Independence of Judiciary } \\
\text { - Irregular Payments } \\
\text { - Sound Legal Framework } \\
\text { - Regulatory Burden } \\
\text { - Level of Administrative Corruption } \\
\text { - Honoring of Policies through Government } \\
\text { Transition }\end{array}$} & \multicolumn{2}{|c|}{$\begin{array}{l}\text { Scientific \& Technical Infrastructure } \\
\text { - Scientists and Engineers per capita } \\
\text { - Country Technology Position } \\
\text { - Institutions } \\
\text { - Licensing of Foreign Technologies } \\
\text { - Company R\&D Spending } \\
\text { - Willingness to Absorb New Technology } \\
\text { - Importance of Innovation to Revenue } \\
\text { - Government Purchase Decision for } \\
\text { Technology Products }\end{array}$} \\
\hline
\end{tabular}

Source: Esty, D. C., \& Porter, M. E. (2005). "National environmental performance: An empirical analysis of policy results and determinants." Faculty Scholarshop Series, Paper 430, Figure 1, p. 395. 


\section{Appendix E}

\section{World Values Survey Questions}

\section{An Excerpt about the World Values Survey:}

The World Values Survey is a worldwide investigation of sociocultural and political change. It is conducted by a network of social scientist at leading universities all around world. Interviews have been carried out with nationally representative samples of the publics of almost hundred societies on all six inhabited continents. The first wave of the values survey was collected in 198. This was mainly a European endeavor (se EVS). From the second wave the global representation rose dramatically making it possible to carry out reliable global cross-cultural analyses and analysis of changes over time. The World Values Survey has produced evidence of gradual but pervasive changes in what people want out of life. Moreover, the survey shows that the basic direction of these changes is, to some extent, predictable. More than 80 independent countries have been surveyed in at least one wave of this investigation. These countries include almost 85 percent of the world's population. This unique database makes it possible to examine cross-level linkages, such as that between public values and economic growth; or between environmental pollution and mass attitudes toward environmental protection.

Source: http://www.worldvaluessurvey.org/index_surveys

\section{World Values Survey Questions Used in this Study}

V96 Political action: signing a petition

V97 Political action: joining in boycotts

V98 Political action: attending lawful/peaceful demonstrations

V104 Protecting environment vs. economic growth

See following page for World Values Survey questions considered but not used in this study. 


\section{World Values Survey Questions Considered but Not Used in this Study}

V29 Active/inactive membership of environmental organization

V69 Aims of country - first choice: a high level of economic growth; strong defense forces; people have more say about how things are done; trying to make our cities and countryside more beautiful

V73 First choice: a stable economy; progress toward a less impersonal and more humane society; ideas count more than money; the fight against crime

V105 Would give part of my income for the environment

V106 Increase in taxes if used to prevent environmental pollution

V107 Government should reduce environmental pollution

V111 Environmental problems in the world: Global warming or the greenhouse effect

V112 Environmental problems in the world: Loss of plant or animal species or biodiversity

V113 Environmental problems in the world: Pollution of rivers, lakes and oceans

V122 Belief in control of life: fate versus destiny

V143 Confidence in the environmental protection movement

V151 Governing: having a democratic political system (very good - very bad scale)

V162 Importance of democracy for you to live in that country

V166 Most serious problem of the world - first choice: people living in poverty and need; discrimination against girls and women; poor sanitation and infectious diseases; inadequate education; environmental pollution

V162 Importance of democracy for you to live in that country

V184 How often do you think about the meaning and purpose of life

V187 Religious person: atheist, not a religious person, a religious person

V210 I see myself as a world citizen

V212 I see myself as a citizen of the nation

Note: Questions were retrieved from World Values Survey 1981-2008 Official Aggregate v.20090901, 2009. World Values Survey Association (www.worldvaluessurvey.org). Aggregate File Producer: ASEP/JDS, Madrid. 


\section{Appendix F}

\section{World Bank/ISI List of Developing Countries (2010-2013)}

\begin{tabular}{|c|c|c|}
\hline Afghanistan & Guinea & Panama \\
\hline Albania & Guinea-Bissau & Papua New Guinea \\
\hline Algeria & Guyana & Paraguay \\
\hline American Samoa & Haiti & Peru \\
\hline Angola & Honduras & Philippines \\
\hline Argentina & India & Romania \\
\hline Armenia & Indonesia & Russian Federation \\
\hline Azerbaijan & Iran, Islamic Rep. of & Rwanda \\
\hline Bangladesh & Iraq & Samoa \\
\hline Belarus & Jamaica & Sao Tome and Principe \\
\hline Belize & Jordan & Senegal \\
\hline Benin & Kazakhstan & Serbia \\
\hline Bhutan & Kenya & Seychelles \\
\hline Bolivia & Kiribati & Sierra Leone \\
\hline Bosnia and Herzegovina & Korea, Democ.P.Rep.of & Solomon Islands \\
\hline Botswana & Kosovo & Somalia \\
\hline Brazil & Kyrgyz Republic & South Africa \\
\hline Bulgaria & Lao People's Democ.Rep. & South Sudan \\
\hline Burkina Faso & Latvia & Sri Lanka \\
\hline Burundi & Lebanon & St. Kitts and Nevis \\
\hline Cambodia & Lesotho & St. Lucia \\
\hline Cameroon & Liberia & St. Vincent and the Grenadines \\
\hline Cape Verde & Libya & Sudan \\
\hline Central African Republic & Lithuania & Suriname \\
\hline Chad & Macedonia, the F.Y.R.of & Swaziland \\
\hline Chile & Madagascar & Syrian Arab Republic \\
\hline China & Malawi & Tajikistan \\
\hline Colombia & Malaysia & Tanzania, United Republic of \\
\hline Comoros & Maldives & Thailand \\
\hline Congo, Democ.Rep.of the & Mali & Timor-Leste \\
\hline Congo, Rep & Marshall Islands & Togo \\
\hline Costa Rica & Mauritania & Tonga \\
\hline Cote d'Ivoire & Mauritius & Tunisia \\
\hline Cuba & Mexico & Turkey \\
\hline Djibouti & Micronesia, Fed.States of & Turkmenistan \\
\hline Dominica & Moldova & Tuvalu \\
\hline Dominican Republic & Mongolia & Uganda \\
\hline Ecuador & Montenegro & Ukraine \\
\hline Egypt, Arab Rep. & Morocco & Uruguay \\
\hline El Salvador & Mozambique & Uzbekistan \\
\hline Eritrea & Myanmar & Vanuatu \\
\hline Ethiopia & Namibia & Venezuela \\
\hline Fiji Gabon & Nepal & Vietnam \\
\hline Gambia, The & Nicaragua & West Bank and Gaza \\
\hline Georgia & Niger & Yemen \\
\hline Ghana & Nigeria & Zambia \\
\hline Grenada & Pakistan & Zimbabwe \\
\hline Guatemala & Palau & \\
\hline
\end{tabular}




\section{Developing Countries}

The list of developing countries in this Appendix was retrieved from the World Bank. As of September, 2012, the World Bank identified developing countries as follows:

"The list of developing countries shown...is adhered to by the ISI, effective from 1 January till 31 December 2013. Countries are divided into developed or developing according to their Gross National Income (GNI) per capita per year. Countries with a GNI of US\$11,905 and less in 2010 are defined as developing."

Source: http://www.isi-web.org/component/content/article/5-root/root/81-developing 


\section{Appendix G}

\section{The Global Competitiveness Report and}

\section{GCI Technological Readiness Scores}

\section{The Global Competitiveness Report}

\section{Following is an excerpt of the description of The Global Competitiveness Report:}

The World Economic Forum has, for more than three decades, played a facilitating role in this process by providing detailed assessments of the productive potential of nations worldwide. The Report contributes to an understanding of the key factors that determine economic growth, helps to explain why some countries are more successful than others in raising income levels and opportunities for their respective populations, and offers policymakers and business leaders an important tool in the formulation of improved economic policies and institutional reforms. This year's Report features a record number of 144 economies, and thus continues to be the most comprehensive assessment of its kind. It contains a detailed profile for each of the economies included in the study as well as an extensive section of data tables with global rankings covering over 100 indicators. This Report remains the flagship publication within the Forum's Global Benchmarking Network, which produces a number of research studies that mirror the increased integration and complexity of the world economy (Schwab, 2012, p. xiii).

For more than three decades, the World Economic Forum's annual Global Competitiveness Reports have studied and benchmarked the many factors underpinning national competitiveness. From the onset, the goal has been to provide insight and stimulate the discussion among all stakeholders on the best strategies and policies to help countries to overcome the obstacles to improving competitiveness. In the current challenging economic environment, our work is a critical reminder of the importance of structural economic fundamentals for sustained growth. Since 2005, the World Economic Forum has based its competitiveness analysis on the Global Competitiveness Index (GCI), a comprehensive tool that measures the microeconomic and macroeconomic foundations of national competitiveness. We define competitiveness as the set of institutions, policies, and factors that determine the level of productivity of a country. The level of productivity, in turn, sets the level of prosperity that can be earned by an economy. The productivity level also determines the rates of return obtained by investments in an economy, which in turn are the fundamental drivers of its growth rates. In other words, a more competitive economy is one that is likely to sustain growth. The concept of competitiveness thus involves static and dynamic components. Although the productivity of a country determines its ability to sustain a high level of income, it is also one of the central determinants of its returns to investment, which is one of the key factors explaining an economy's growth potential (Schwab, 2012, p. 4). 


\section{GCI Technological Readiness Scores}

Following is an excerpt of the description of GCI Technological Readiness Scores, as published in The Global Competitiveness Report:

In today's globalized world, technology is increasingly essential for firms to compete and prosper. The technological readiness pillar measures the agility with which an economy adopts existing technologies to enhance the productivity of its industries, with specific emphasis on its capacity to fully leverage information and communication technologies (ICT) in daily activities and production processes for increased efficiency and enabling innovation for competitiveness. ICT has evolved into the "general purpose technology" of our time, given the critical spillovers to the other economic sectors and their role as industry-wide enabling infrastructure. Therefore ICT access and usage are key enablers of countries' overall technological readiness. Whether the technology used has or has not been developed within national borders is irrelevant for its ability to enhance productivity. The central point is that the firms operating in the country need to have access to advanced products and blueprints and the ability to absorb and use them. Among the main sources of foreign technology, FDI often plays a key role, especially for countries at a lower stage of technological development. It is important to note that, in this context, the level of technology available to firms in a country needs to be distinguished from the country's ability to conduct blue-sky research and develop new technologies for innovation that expand the frontiers of knowledge (Schwab, 2012, p. 6). 